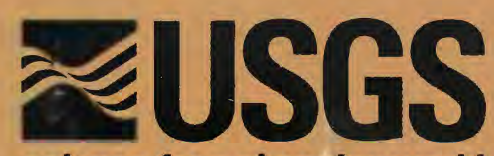

science for a changing world

\title{
Selected Geochemical and Biogeochemical Studies of the Fortymile River Watershed, Alaska
}

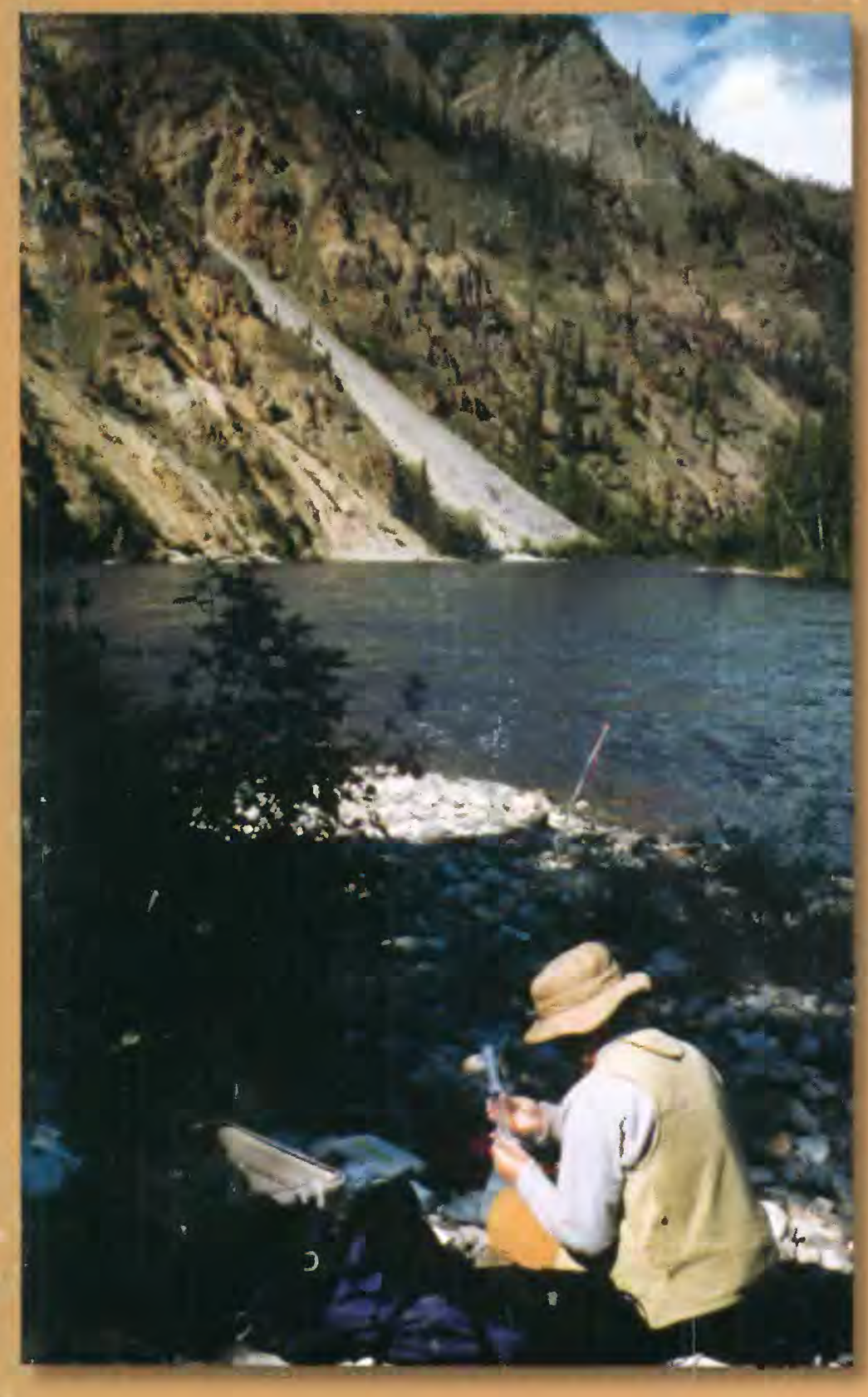

Professional Paper 1685

U.S. Department of the Interior U.S. Geological Survey 


\section{Selected Geochemical and Biogeochemical Studies of the Fortymile River Watershed, Alaska}

Larry P. Gough, Editor

Professional Paper 1685 


\title{
U.S. Department of the Interior \\ Gale A. Norton, Secretary
}

\author{
U.S. Geological Survey \\ Charles G. Groat, Director
}

\author{
U.S. Geological Survey, Reston, Virginia: 2004 \\ For sale by U.S. Geological Survey Information Services \\ Box 25286, Denver Federal Center \\ Denver, C0 80225 \\ This report and any updates to it are available online at: \\ http://pubs.usgs.gov/pp/p1685/ \\ Additional USGS publications can be found at: \\ http://geology.usgs.gov/products.html \\ For more information about the USGS and its products: \\ Telephone: 1-888-ASK-USGS (1-888-275-8747) \\ World Wide Web: http://www.usgs.gov/
}

Any use of trade, product, or firm names in this publication is for descriptive purposes only and does not imply endorsement of the U.S. Government.

Although this report is in the public domain, it contains copyrighted materials that are noted in the text. Permission to reproduce those items must be secured from the individual copyright owners.

Cataloging-in-publication data are on file with the Library of Congress (URL http://www.loc.gov/).

COVER Fortymile River near the mouth of Moose Creek. This section of the river, just a few miles west of the United States-Canadian border, cuts through supracrustal metasedimentary rocks of the Taylor Mountain assemblage. The geochemical influence of this and other lithologic units on surface-water chemistry and fish-tissue biogeochemistry is the subject of the first two chapters in this report. The brown color of the river water is due to the abundance of natural organic matter, which plays a role in the transport and complexation of dissolved metals-the subject of the third chapter in this report. 


\section{Contents}

[Numbers designate chapters]

Introduction

By Larry P. Gough

1. Geochemical Processes and Geologic Framework Influencing Surface-Water and

Sediment Chemistry in the Fortymile River Watershed, East-Central Alaska.

3

By Bronwen Wang, Richard B. Wanty, and Jim Vohden

2. Biogeochemistry, Stable-Isotopic Composition, and Feeding Habits of Arctic Grayling

(Thymallus arcticus) in the Lower Fortymile River, Eastern Alaska..

By Larry P. Gough, James G. Crock, Robert R. Seal, Bronwen Wang, and

Phyllis Weber-Scannell

3. Comparative Characteristics of Natural Organic Matter in the Fortymile River, Alaska..

45

By Donald L. Macalady, Kaylene Ritter, Aaron D. Redman, and Magnus Skold

4. U.S. Geological Survey Reports on the Fortymile River Watershed-Products of Recent Mineral Resources Program Studies. 


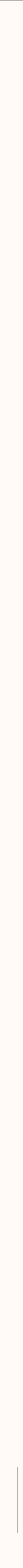




\title{
Introduction
}

\author{
By Larry P. Gough
}

The collection of three papers that follow results from hydrologic, geologic, geochemical, and biogeochemical studies begun in 1997 in the Fortymile River watershed, east-central Alaska. These studies are the latest in a series of publications (see bibliography at end of this report), resulting from work focused on the mineral-rich Yukon-Tanana Upland (YTU) physiographic region (Interior Highlands Ecoregion), conducted by the U.S. Geological Survey (USGS)'s Mineral Resources Program.

The YTU has a long history related to the mining and mineral industry. Placer gold was first discovered in the Fortymile River in 1886, and both alluvial and lode deposits have been exploited within the region. The development of low- to high-grade, high-tonnage, intrusion-related Au deposits (such as Fort Knox, True North, and Pogo) since the early 1990s is a new resource that has spurred a resurgence of exploration activity. Numerous State and Federal regulations require that the degree of potentially adverse environmental impact from these exploration and mining activities be quantified, especially for surface-water quality and its influence on the health of aquatic biota. By helping to establish regional premining baselines, these and other studies will aid regulatory decisions at the local, State, and Federal levels, as well as help the mining companies formulate efficient mitigation plans.

The USGS, the Bureau of Land Management, and the Alaska Department of Natural Resources are cooperating in project work to provide the scientific data for upcoming decisions that involve State and Federal land-use options and their regulations. One important question that relates to resource development is "what are the regional predevelopment geochemical 'signatures' (or baselines) for water and biota, and what impact do natural processes have on the variation in those 'signatures"'? This question is especially important because it applies to trace elements, particularly if those trace elements have environmental importance (that is, are metaboli- cally active, possibly even toxic, in plants and animals). By understanding the predevelopment baselines, changes suspected to have been caused by human activity can be defined and quantified.

The chapters in this report provide a framework for the analysis of future, potential changes in geochemical and biogeochemical signatures, because they report the quantitative analysis of water, sediment, rocks, and fish tissue. They also report on the processes that affect the mobility and bioavailability of certain trace elements. The chapter by Wang and others discusses major- and trace-element chemistry in relation to regional lithologic units within the Fortymile River watershed. The major-ion chemistry of the waters reflects a rock-dominated aqueous system with but limited interaction with the geologic materials of the region. The authors discuss in detail the multiple and varied reasons for this apparent paradox. The chapter by Gough and others examines the chemistry of fish tissue (Arctic grayling) and reports functional biogeochemical baseline values and (or) ranges for numerous elements, including mercury. This chapter also examines the nitrogen-, carbon-, and sulfur-isotopic composition of fish tissue in relation to grayling food sources and trophic position in the food web. Finally, the chapter by Macalady and others discusses the role of dissolved natural organic matter on the mobility of trace elements in waters. Measurements of the copper-complexation capacities of these samples confirm that the dissolved organic matter has very low metal-binding capacities. The authors discuss the importance of this discovery in relation to future potential mining activities.

The bibliography at the end of this report lists all the publications that were generated by this project from 1997 to the present, some of which are available in their entirety online, whereas others may be obtained from the USGS library (URL http://library.usgs.gov/) or from USGS Information Services (URL http://mapping.usgs.gov/esic/to_order.html). 


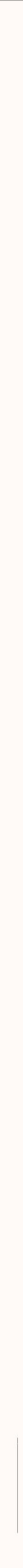




\title{
Chapter 1
}

\section{Geochemical Processes and Geologic Framework Influencing Surface-Water and Sediment Chemistry in the Fortymile River Watershed, East-Central Alaska}

\author{
By Bronwen Wang, Richard B. Wanty, and Jim Vohden ${ }^{1}$
}

\section{Contents}

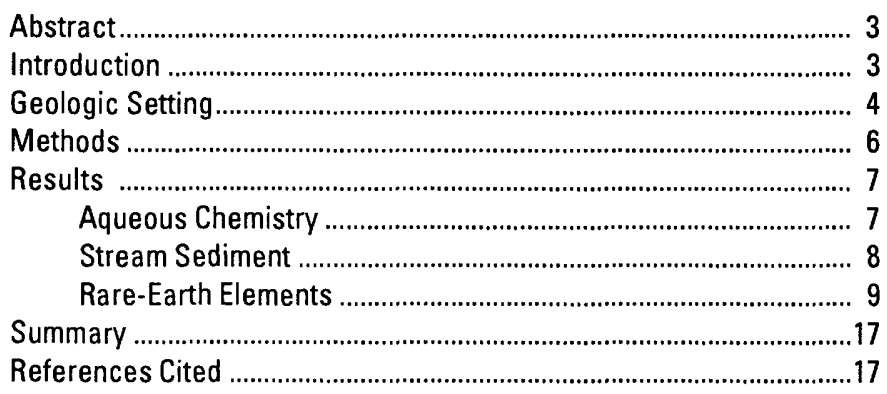

\section{Abstract}

We have analyzed major, trace, and rare-earth elements in water and stream-sediment samples from 33 sites within the Fortymile River Basin. The major-ion chemistry of the basin is relatively uniform. Stream waters are classified primarily as $\mathrm{Ca}^{2+}$ and $\mathrm{Mg}^{2+}-\mathrm{HCO}_{3}^{-}$to mixed $\mathrm{Ca}^{2+}$ and $\mathrm{Mg}^{2+}-\mathrm{HCO}_{3}^{-}$and $\mathrm{SO}_{4}^{2-}$ type. The major-ion chemistry of the waters reflects a rockdominated aqueous system with but limited interaction with the geologic materials of the region. Trace-element concentrations in water are generally low; however, some dissolved $\mathrm{Cu}$ contents exceeded the freshwater-aquatic-life standard for chronic exposure. Stream-sediment $\mathrm{As}, \mathrm{Cu}, \mathrm{Hg}$, and $\mathrm{Zn}$ contents ranged from below the Canadian interim sediment-quality guideline (ISQG) to above the ISQG but below the probable-effects limit (PEL). All the sites exceeded the ISQG for $\mathrm{Cr}$, and nine exceeded the PEL; however, what effect, if any, these levels might have on the stream biota in this aqueous system is unclear. The streams draining metavolcanic rocks had the highest $\mathrm{Cr}$ contents in sediment, possibly reflecting the $\mathrm{Cr}$ contents of the mafic metavolcanic rocks.

Total rare-earth-element (REE) concentrations range from $<0.61$ to $15 \mu \mathrm{g} / \mathrm{L}$ and from 103 to $171 \mathrm{mg} / \mathrm{kg}$ for aqueous and

\footnotetext{
'Alaska Department of Natural Resources.
}

stream-sediment samples, respectively. Total aqueous REE concentrations were positively correlated with the amount of suspended colloidal matter but not correlated with the $\mathrm{pH}$ of the water.

\section{Introduction}

The Fortymile River lies within the "Tintina Gold Belt" and is within the Yukon-Tanana Upland physiographic province (fig. 1). Placer gold has been mined in the Fortymile River region since 1886 (Mertie, 1938; Yeend, 1996), and gold exploration and development in the Tintina Gold Belt has recently expanded because of the discoveries of the Fort Knox, True North, and Pogo deposits (Goldfarb and others, 2000). Between 1997 and 1998, the U.S. Geological Survey and the Alaska Department of Natural Resources conducted a cooperative study in the Fortymile River watershed to provide background geochemical data for this region. The effects of current placer-mining operations on the Fortymile River and the chemical composition of bedrock, soils, and vegetation in the Fortymile River Basin have been reported elsewhere (Crock and others, 1999, 2000; Wanty and others, 2000; Gamble and others, 2001; Gough and others, 2001). In this chapter, we focus on the chemical characteristics of surface water and stream sediment within the basin, evaluating the major ions, trace elements, and rare-earth elements (REEs) in the context of the geologic setting.

Interest in REE mobility in riverine environments has increased in recent years. Previously, REEs had been considered to be relatively immobile in many geologic environments. With advances in analytical-chemical techniques, however, many studies have shown REE fractionation during soil development and mobility in ground waters, surface waters, and thermal springs (Keasler and Liveland, 1982; Cullers and others, 1987; Goldstein and Jacobson, 1988; Elderfield and others, 1990; Smedley, 1991; Ohlander and others, 1996; Morey and Setterholm, 1997; Banks and others, 1999; Tricca and others, 1999; Johannesson and others, 2000). As a result, REE mobility is 
now widely accepted, and several studies have used REEs as hydrologic tracers (Johannesson and others, 1997; Worrall, 2001).

Brookins (1989) and Wood (1990) reviewed the aqueous geochemistry of REEs. With the exception of $\mathrm{Ce}(\mathrm{IV})$ and $\mathrm{Eu}$ (II), all REEs occur in nature in a $3+$ oxidation state, and the ionic size decreases from $\mathrm{La}^{3+}$ to $\mathrm{Lu}^{3+}$ because of the lanthanide contraction (see Greenwood and Earnshaw, 1984). The lanthanides are considered "hard acids" and readily form complexes with such hard bases as $\mathrm{CO}_{3}^{2-}, \mathrm{PO}_{4}^{3-}, \mathrm{SO}_{4}^{2-}, \mathrm{F}^{-}$, and $\mathrm{OH}^{-}$. The distribution of REEs in water and sediment depends on the distribution and fractionation characteristics of the geologic material, the preferential dissolution of REEs containing mineral phases during weathering, and the formation and presence of secondary minerals and colloidal matter (Banks and others, 1999).

REEs are commonly normalized to either chondrite or the North American Shale Composite (NASC) (Goldstein and Jacobsen, 1988; McLennan, 1989). Such normalization smoothes the inherent difference in abundance of the individual elements in the lanthanide series. Chondrite is believed to represent the cosmic and bulk-earth abundance, whereas the NASC represents the average upper-continental crust. Fractionation during weathering can give rise to normalized patterns that are enriched or depleted in light REEs (LREEs), and the redox behavior of $\mathrm{Ce}$ and $\mathrm{Eu}$ can lead to either positive or negative anomalies, depending on environmental conditions.

One measure of the relative fractionation of REEs is given by the normalized $\mathrm{La} / \mathrm{Yb}$ ratio:

$$
(\mathrm{La} / \mathrm{Yb})_{\mathrm{n}}=(\mathrm{La} / \mathrm{Yb})_{\text {sample }} /(\mathrm{La} / \mathrm{Yb})_{\text {standard }}
$$

$(\mathrm{La} / \mathrm{Yb})_{\mathrm{n}}>1$ indicates $\mathrm{LREE}$ enrichment in a sample relative to the normalizing component, $(\mathrm{La} / \mathrm{Yb})_{n}<1$ indicates relative
LREE depletion, and $(\mathrm{La} / \mathrm{Yb})_{\mathfrak{n}} \sim 1$ indicates little internal REE fractionation. $\mathrm{Ce}$ and Eu anomalies are expressed herein as $\mathrm{Ce}^{*}$ and $\mathrm{Eu} / \mathrm{Eu}^{*}$, given by $\mathrm{Ce}{ }^{*}=3 \mathrm{Ce}_{\mathrm{n}} /\left(2 \mathrm{La}_{\mathrm{n}}+\mathrm{Nd}_{\mathrm{n}}\right)$ and $\mathrm{Eu} /$ $\mathrm{Eu}^{*}=\mathrm{Eu}_{\mathrm{n}} /\left(\mathrm{Sm}_{\mathrm{n}} \times \mathrm{Gd}_{\mathrm{n}}\right)^{0.5}$, respectively, where the subscript " $n$ " denotes the normalized concentration (Goldstein and Jacobsen, 1988; Elderfield and others, 1990).

\section{Geologic Setting}

The bedrock geology and geochemistry of the Fortymile River area have been discussed in detail elsewhere (Foster and others, 1994; Hansen and Dusel-Bacon, 1998; Day and others, 2000, 2002; Szumigala and others, 2000a, b; Gamble and others, 2001). The major lithologic units in the study area compose a supracrustal sequence of volcanic and sedimentary rocks that have been intruded by Mississippian biotite tonalite (Day and others, 2002). The metasedimentary and mafic metavolcanic rocks were deposited on a continental margin or distal to an island-arc complex. Recrystallization of the entire package during intense Jurassic deformation and dynamic metamorphism almost entirely obscured the original sedimentary fabrics (Dusel-Bacon and others, 1995). A posttectonic granitic suite, chemically similar to other volcanic-arc granites, intrudes the entire sequence (Day and others, 2002).

The metasedimentary rocks consist of biotite schist, quartzite, and marble. The biotite schist and quartzite constitute end members of a compositional continuum defined primarily by the proportion of micaceous material (Gamble and others, 2001). The mineralogy of the biotite schist consists of quartz+biotite \pm white mica \pm garnet \pm hornblende. The marble

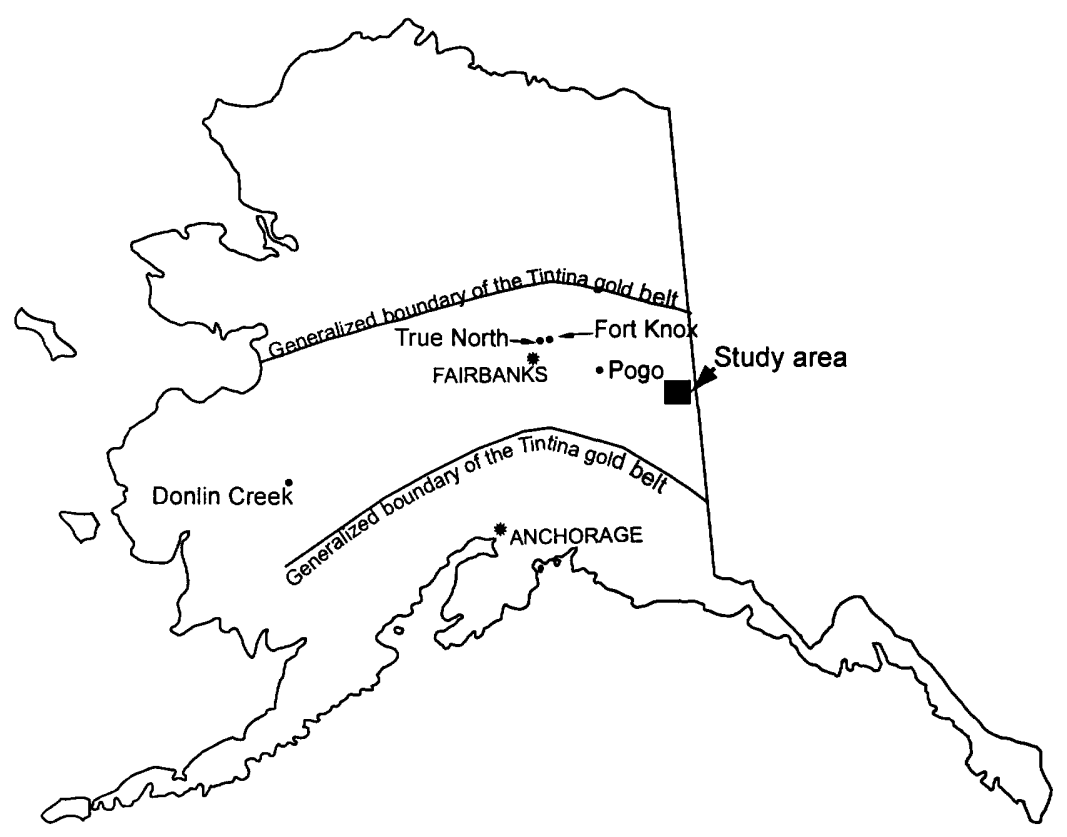

Figure 1. Sketch map of Alaska, showing location of study area within the Tintina Gold Belt and relative to several major gold deposits (dots) and cities (asterisks). 
contains as much as 5 volume percent white mica, biotite, amphibole, and (or) pyrite.

The metavolcanic rocks are predominantly basalt; no metavolcanic rocks of felsic composition have been observed (Day and others, 2002). The mafic metavolcanic rocks contain plagioclase + hornblende \pm biotite \pm clinopyroxene \pm garnet \pm quartz and are fine- to medium-grained, dark-green to black amphibolite gneiss, with both a tholeiitic and a tholeiitic to calc-alkaline series (Dusel-Bacon and Cooper, 1999; Day and others, 2000). Higher $\mathrm{Cr}$ and $\mathrm{Cu}$ contents were reported in the mafic metavolcanic rocks relative to the other rock types (Gamble and others, 2001).

The southeastern part of the study area (fig. 1) is largely underlain by tonalitic orthogneiss (Steel Creek Dome Orthogneiss) that occurs as interlayers within the supracrustal rocks and as small bodies which intrude the sequence (Day and others, 2000, 2002; Gamble and others, 2001). The orthogneiss is light gray, fine to medium grained, and gneissic and generally consists of plagioclase, quartz, biotite, muscovite, and alkali feldspar, with accessory apatite, opaque minerals, and zircon (Gamble and others, 2001). The tonalitic gneiss is transitional in composition from metaluminous to peraluminous.

Day and others (2000) distinguished four basic chondritenormalized REE patterns in the lithologic units of the study area (fig. 2). The metasedimentary rocks are LREE enriched and have a negative Eu anomaly. The metavolcanic rocks exhibit two patterns: one characterized by LREE depletion and another by LREE enrichment (referred to as metavolcanic rock groups I and II, respectively, by Day and others, 2000). The tonalites are LREE enriched and have a small, positive or negative Eu anomaly. In addition, much of the Fortymile River area is overlain by loess. LREE concentrations within the loess are generally higher than in the bedrock (fig. 2). The loess is LREE enriched relative to chondrite, with a negative Eu anomaly.

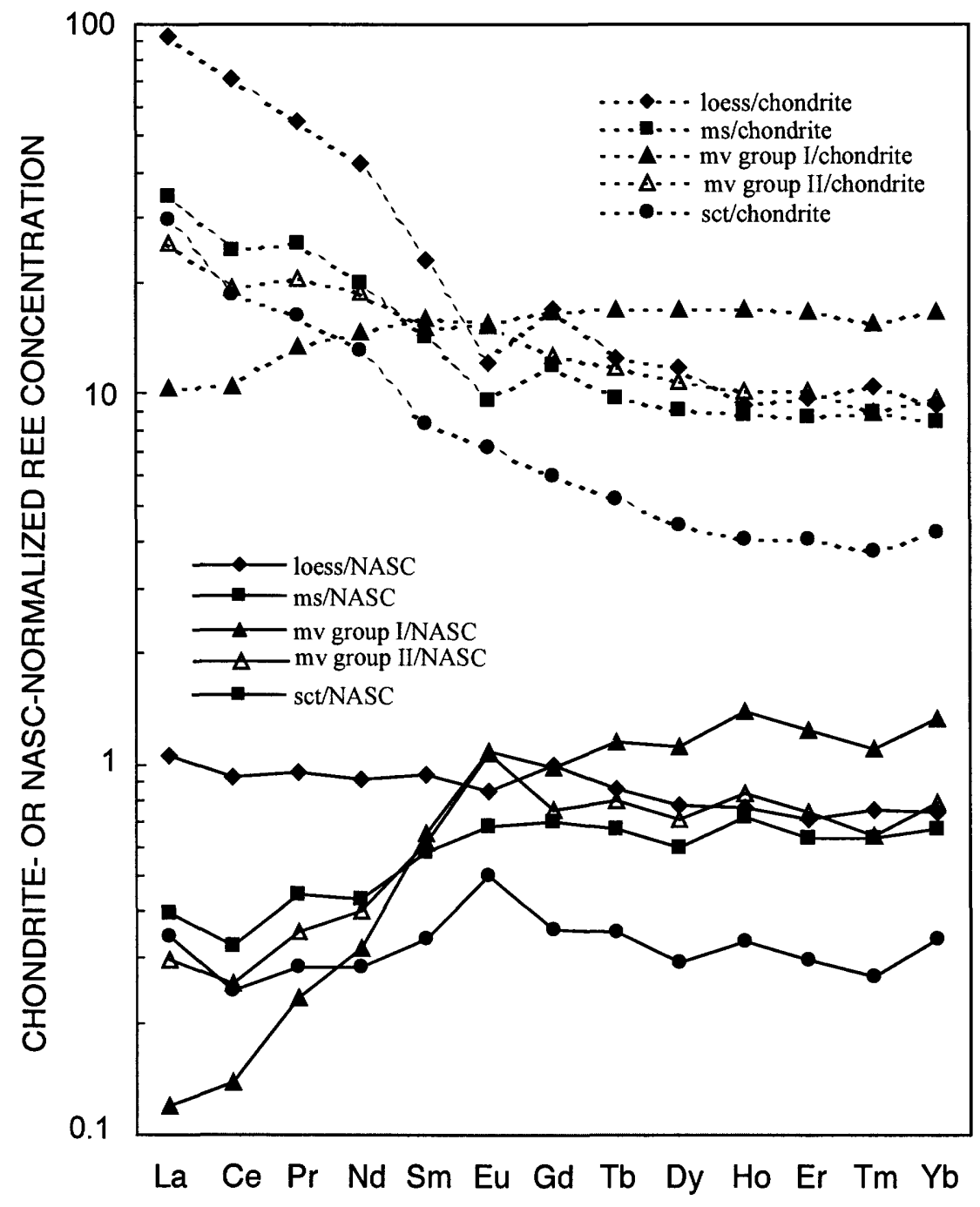

Figure 2. Chondrite- or North American Shale Composite (NASC)-normalized rareearth-element (REE) concentrations in bedrock and loess of the Fortymile River Basin, eastern Alaska (fig. 1). Bedrock values are mean REE concentrations reported by Crock and others (1999) and Day and others (2000); loess values are those of L.P. Gough (unpub. data, 1998). ms, metasediment; mv, metavolcanic; sct, Steele Creek tonalite. 


\section{Methods}

A total of 33 sites were sampled during June and July 1997 and 1998 (fig. 3). In the text, sites are referred to by the creek name. Complete analytical data for these sites were reported by Crock and others (1999, 2000); 1997 analytical data for anions were omitted from these reports and are listed in table 1. Water samples were collected in both 1997 and 1998 at three sites on the North Fork of the Fortymile River, Buck Creek, and O'Brien Creek for interannual comparison. Major-ion and trace-element chemical analyses are available for both water and stream-sediment samples at all sites, but REE and $\mathrm{Hg}$ analyses are unavailable for the 1997 streamsediment samples. In addition, stream-sediment samples were not collected on the tributaries to Uhler Creek or on the South Fork or main stem of the Fortymile River.

Details of the sampling and analysis were presented by Crock and others $(1999,2000)$ and Wanty and others (2000). In general, water samples were depth- and widthintegrated composite samples filtered through a $0.45-\mu \mathrm{m}$ filter. Samples for cation analysis were acidified with ultra-high-purity $\mathrm{HNO}_{3}$. The filtered water samples are considered to represent the dissolved metals for comparison with the U.S. Environmental Protection Agency's standard; however, colloids $<0.45 \mu \mathrm{m}$ could be present in these samples. Measurements of $\mathrm{pH}$, electrical conductivity, temperature, turbidity, and stream discharge were performed in the field. Sediment samples were bulk composites from active depositional zones within the stream. Several depositional areas were sampled and combined to obtain sufficient material for analysis. In the laboratory, sediment samples were dried, sieved to minus- 80 mesh, and ground before analysis by inductively coupled plasma mass spectrometry (ICP-MS). Sampling and analytical methods followed established standard procedures (Wood, 1976; Fishman and Pyen, 1979; Lichte and others, 1987; Meier and others, 1994). Cations and trace metals were analyzed by ICP-MS (Meier and others, 1994); anions were analyzed by ion chromatography, following the techniques of Fishman and Pyen (1979).

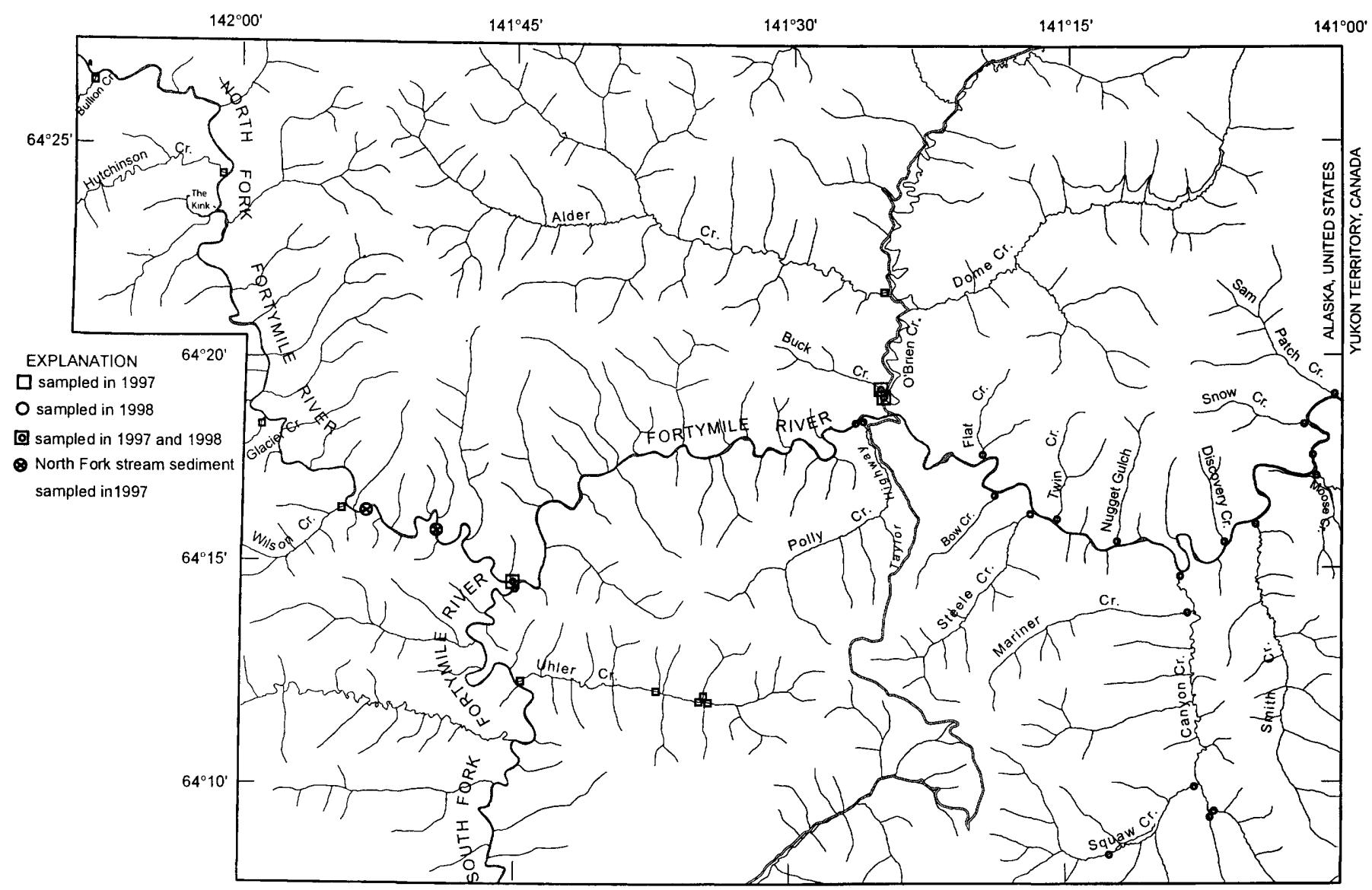

Base data for hydrography and roads from USGS 1: 63,360 scale digital line graphs for Eagle $A-1$ A-2, B-1, B-2, and B-3 quadrangles. Universal Transverse Mercator projection, 1927 North American Datum.
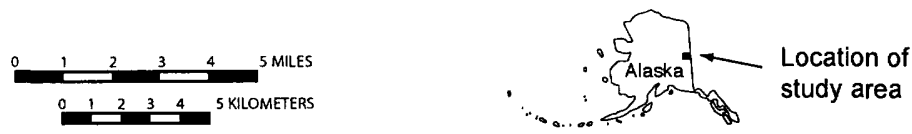

Figure 3. Fortymile River Basin, eastern Alaska (fig. 1), showing locations of 1997 and 1998 water- and stream-sediment-sampling sites. 
Table 1. Major-anion concentrations in surface water samples from the Fortymile River Basin, eastern Alaska.

[See figures 1 and 3 for locations. Samples collected in 1997, numbered according to Crook and others (1999). All values in milligrams per liter; dashes, not measured. IC, ion chromatography]

\begin{tabular}{|c|c|c|c|c|c|c|}
\hline Sample & Description & $\mathrm{F}$ & $\mathrm{Cl}$ & $\mathrm{NO}_{3}^{-}$ & $\mathrm{SO}_{4}^{2-}$ & $\begin{array}{l}\text { Alkalinity } \\
\text { as } \mathrm{CaCO}_{3}\end{array}$ \\
\hline $97 \mathrm{AK}-01-\mathrm{A}$ & Buck Creek - -........- & 0.09 & 0.18 & .39 & 5 & 87 \\
\hline $97 \mathrm{AK}-01-\mathrm{B}$ & Buck Creek Duplicate-- & -- & -- & .42 & 5 & -- \\
\hline $97 \mathrm{AK}-06 \mathrm{~W}$ & Hutchinson Creek -...-...-...-. & .13 & .13 & .55 & 21 & 48 \\
\hline $97 \mathrm{AK}-07 \mathrm{~W}-\mathrm{A}$ & Bullion Creek-1- & .19 & .13 & .79 & 14 & 58 \\
\hline $97 \mathrm{AK}-07 \mathrm{~W}-\mathrm{B}$ & Split of Bullion Creek - & -- & -- & .73 & 14 & 58 \\
\hline $97 \mathrm{AK}-08 \mathrm{~W}$ & Glacier Creek - & .18 & .18 & .96 & 10 & 28 \\
\hline $97 \mathrm{AK}-09 \mathrm{~W}-\mathrm{A}$ & Wilson Creek - & .15 & .14 & .86 & 41 & 41 \\
\hline $97 \mathrm{AK}-09 \mathrm{~W}-\mathrm{B}$ & Wilson Creek duplicate - & -- & -- & .87 & 42 & 41 \\
\hline $97 \mathrm{AK}-10 \mathrm{~W}$ & $\begin{array}{l}\text { Uhler Creek at confluence with the South Fork } \\
\text { of the Fortymile River. }\end{array}$ & .10 & .19 & .89 & 14 & 22 \\
\hline $97 \mathrm{AK}-11 \mathrm{~W}$ & Uhler Creek at mining operation & .10 & .10 & 1.10 & 6 & 19 \\
\hline $97 \mathrm{AK}-12 \mathrm{~W}$ & Uhler Creek above mining & .09 & .08 & .75 & 8 & 17 \\
\hline $97 \mathrm{AK}-13 \mathrm{~W}$ & Unnamed tributary to Uhler Creek -..-- & .11 & .10 & .54 & 13 & 13 \\
\hline $97 \mathrm{AK}-14 \mathrm{~W}$ & Uhler Creek above tributary & .09 & .07 & .85 & 7 & 18 \\
\hline $97 \mathrm{AK}-15 \mathrm{~W}-\mathrm{A}$ & Alder Creek - & .14 & .40 & .39 & 64 & 103 \\
\hline $97 \mathrm{AK}-16 \mathrm{~W}$ & O'Brien Creek - & .12 & .38 & 8.10 & 13 & 77 \\
\hline $97 \mathrm{AK}-18 \mathrm{~W}$ & $\begin{array}{l}\text { North Fork of the Fortymile River above } \\
\text { confluence with the South Fork. }\end{array}$ & .12 & .83 & .31 & 23 & 53 \\
\hline
\end{tabular}

\section{Results}

\section{Aqueous Chemistry}

The major- and trace-element concentrations in water samples are listed in table 2 . As illustrated by a Piper plot (fig. 4), the stream waters are classified primarily as $\mathrm{Ca}^{2+}$ and $\mathrm{Mg}^{2+}$ $\mathrm{HCO}_{3}^{-}$to mixed $\mathrm{Ca}^{2+}$ and $\mathrm{Mg}^{2+}-\mathrm{HCO}_{3}^{-}$and $\mathrm{SO}_{4}^{2-}$ type. At seven sites-Wilson, Creek, Steel Creek, Smith Creek, Flat Creek, Polly Creek, Sam Patch Creek, and an unnamed tributary to Uhler Creek $-\geq 50$ percent of the anionic charge was derived from $\mathrm{SO}_{4}^{2-}$. The low content of total dissolved solids indicates that these waters have not undergone extensive interaction with the geologic material of the region. However, the plot of $\mathrm{Na} /(\mathrm{Na}+\mathrm{Ca})$ versus total dissolved solids in the waters lies in the general region of rock-dominated systems as defined by Gibbs (1970) (fig. 5), indicating that the composition of these samples is more rock dominated as opposed to evaporation or precipitation dominated. The minimal water-rock interaction may be due to short flowpaths, partly owing to the presence of permafrost limiting the hydrologic flowpath (Wanty and others, 2000).

$\mathrm{As}, \mathrm{Cd}, \mathrm{Cu}, \mathrm{Pb}, \mathrm{Hg}$, and $\mathrm{Se}$ contents in water are all commonly associated with regulatory concerns. As and Se contents are below the limits of detection $(<3$ and $<0.2 \mu \mathrm{g} / \mathrm{L}$, respectively) in all samples. $\mathrm{Hg}$ was detected in two samples: at the mouth of Smith Creek $(0.005 \mu \mathrm{g} / \mathrm{L})$ and in Steele Creek $(0.014 \mu \mathrm{g} / \mathrm{L})$, both well below both the aquatic-life-standard criteria continuous concentration (CCC) of $0.77 \mu \mathrm{g} / \mathrm{L}$ and the human-health consumption criterion of $0.05 \mu \mathrm{g} / \mathrm{L}$ (U.S. Environmental Protection Agency, 1999). The CCC is defined as the highest concentration of a material in surface water to which an aquatic community can be exposed indefinitely without resulting in an unacceptable effect. The Cd content at 10 sites and the $\mathrm{Pb}$ content at 11 sites were above the limits of detection, ranging from 0.02 to $0.17 \mu \mathrm{g} / \mathrm{L}$ and from 0.05 to

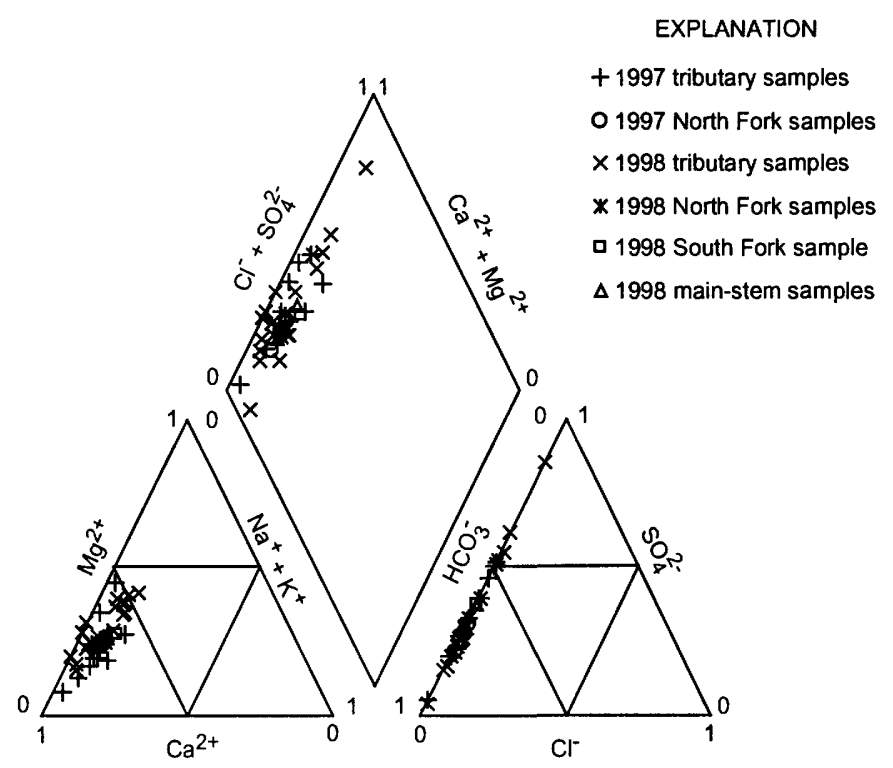

Figure 4. Piper plot of major cations and anions for water samples from the Fortymile River and its tributaries, eastern Alaska (figs. 1, 3). 
Table 2. Summary statistics for the major ions and trace elements in water samples from the Fortymile River and its tributaries.

[See figures 1 and 3 for locations. Statistics not calculated for elements with censored data]

\begin{tabular}{|c|c|c|c|c|c|c|}
\hline Element & $\begin{array}{l}\text { Lower limit } \\
\text { of detection }\end{array}$ & $\begin{array}{l}\text { Arithmetic } \\
\text { mean }\end{array}$ & $\begin{array}{c}\text { Geometric } \\
\text { mean }\end{array}$ & $\begin{array}{l}\text { Geometric } \\
\text { deviation }\end{array}$ & $\begin{array}{l}\text { Observed } \\
\text { range }\end{array}$ & $\begin{array}{l}\text { Proportion } \\
\text { of samples } \\
\text { above } \\
\text { analytical } \\
\text { detection limit }\end{array}$ \\
\hline $\mathrm{Al}(\mu \mathrm{g} / \mathrm{L})$ & 0.1 & 208 & 154.9 & 2.2 & $23-839$ & $36: 36$ \\
\hline As $(\mu \mathrm{g} / \mathrm{L})$ & 3 & -- & -- & -- & $<3$ & $0: 36$ \\
\hline $\mathrm{Ba}(\mu \mathrm{g} / \mathrm{L}) \ldots$ & .1 & 37 & 32 & 2 & $16-76$ & $36: 36$ \\
\hline $\mathrm{Ca}(\mathrm{mg} / \mathrm{L})$ & .05 & 17 & 15 & 2 & $5.6-35$ & $36: 36$ \\
\hline $\mathrm{Cd}(\mu \mathrm{g} / \mathrm{L})$ & .05 & -- & -- & -- & $<.02-0.17$ & $10: 36$ \\
\hline $\mathrm{Cl}(\mathrm{mg} / \mathrm{L})$ & .01 & .27 & .20 & 2.07 & $.06-0.90$ & $36: 36$ \\
\hline $\mathrm{Co}(\mu \mathrm{g} / \mathrm{L})$ & .02 & .54 & .23 & 3.03 & $.03-7.02$ & $36: 36$ \\
\hline $\mathrm{Cr}(\mu \mathrm{g} / \mathrm{L})$ & 1 & 2 & 2 & 2 & $1-5$ & $36: 36$ \\
\hline $\mathrm{Cu}(\mu \mathrm{g} / \mathrm{L})$ & .5 & 4.9 & 4.0 & 1.7 & $2-34.9$ & $36: 36$ \\
\hline F (mg/L) - & .01 & .10 & .10 & 1.50 & $.04-0.19$ & $36: 36$ \\
\hline $\mathrm{Fe}(\mu \mathrm{g} / \mathrm{L})$ & 10 & 293 & 239 & 2 & $53-780$ & $36: 36$ \\
\hline $\mathrm{HCO}_{3}^{-}(\mathrm{mg} / \mathrm{L}) \cdots$ & -- & 54 & 41 & 2 & $12-125$ & $36: 36$ \\
\hline $\mathrm{Hg}(\mu \mathrm{g} / \mathrm{L})$ & .005 & -- & -- & -- & $<.005-0.014$ & $2: 36$ \\
\hline $\mathrm{K}(\mu \mathrm{g} / \mathrm{L})$ & .3 & 816 & 760 & 1.45 & $440-1,700$ & $36: 36$ \\
\hline $\mathrm{Li}(\mu \mathrm{g} / \mathrm{L})$ & .1 & 1.7 & .9 & 3.0 & $.1-17.9$ & $36: 36$ \\
\hline $\mathrm{Mg}(\mathrm{mg} / \mathrm{L})$ & .01 & 4.4 & 3.53 & 2.08 & $1.2-14.7$ & $36: 36$ \\
\hline $\operatorname{Mn}(\mu \mathrm{g} / \mathrm{L})$ & .01 & 20 & 7 & 5 & $.34-163$ & $36: 36$ \\
\hline $\operatorname{Mo}(\mu \mathrm{g} / \mathrm{L}) \ldots$ & .02 & -- & -- & -- & $<.02-1.45$ & $26: 33$ \\
\hline $\mathrm{Na}(\mathrm{mg} / \mathrm{L}) \ldots$ & .01 & 1.7 & 1.47 & 1.68 & $.76-7.39$ & $36: 36$ \\
\hline $\mathrm{Nb}(\mu \mathrm{g} / \mathrm{L})$ & .02 & -- & -- & -- & $<.02-0.2$ & $25: 36$ \\
\hline $\mathrm{Ni}(\mu \mathrm{g} / \mathrm{L})$ & .1 & 3.7 & 2.4 & 2.3 & $.6-33.6$ & $36: 36$ \\
\hline $\mathrm{NO}_{3}^{-}(\mathrm{mg} / \mathrm{L})$ & .05 & .9 & .6 & 2.2 & $.1-8.1$ & $36: 36$ \\
\hline $\mathrm{Pb}(\mu \mathrm{g} / \mathrm{L})$ & .05 & -- & -- & -- & $<.05-0.2$ & $11: 36$ \\
\hline $\mathrm{Rb}(\mu \mathrm{g} / \mathrm{L})$ & .01 & .91 & .89 & 1.44 & $.35-1.81$ & $36: 36$ \\
\hline $\mathrm{Sb}(\mu \mathrm{g} / \mathrm{L}) \ldots$ & .1 & .21 & .2 & 2.0 & $.04-0.74$ & $36: 36$ \\
\hline $\mathrm{Sc}(\mu \mathrm{g} / \mathrm{L}) \ldots$ & .1 & -- & -- & -- & $<.1-1.4$ & $32: 36$ \\
\hline $\mathrm{Se}(\mu \mathrm{g} / \mathrm{L})$ & .2 & -- & -- & -- & $<.5$ & $0: 36$ \\
\hline $\mathrm{SiO}_{2}(\mathrm{mg} / \mathrm{L}) \ldots$ & .5 & 5.3 & 4.9 & 1.4 & $3.2-9.3$ & $36: 36$ \\
\hline $\mathrm{SO}_{4}^{2-}(\mathrm{mg} / \mathrm{L})$ & .05 & 21 & 16 & 2 & $3.3-64$ & $36: 36$ \\
\hline $\mathrm{Sr}(\mu \mathrm{g} / \mathrm{L})$ & .5 & 68 & 58 & 2 & $18-134$ & $36: 36$ \\
\hline $\mathrm{Th}(\mu \mathrm{g} / \mathrm{L})$ & .005 & .18 & .16 & 1.89 & $.03-0.49$ & $36: 36$ \\
\hline $\mathrm{Ti}(\mu \mathrm{g} / \mathrm{L})$ & .1 & 3.3 & 2.8 & 1.8 & $.7-7.9$ & $36: 36$ \\
\hline $\mathrm{U}(\mu \mathrm{g} / \mathrm{L}) \ldots$ & .005 & .4 & .3 & 2.2 & $.07-1.21$ & $36: 36$ \\
\hline$V(\mu \mathrm{g} / \mathrm{L})-\ldots$ & .1 & .9 & .7 & 2.0 & $.2-2.3$ & $36: 36$ \\
\hline $\mathrm{Zn}(\mu \mathrm{g} / \mathrm{L})-\cdots$ & .5 & -- & -- & -- & $<.5-50.1$ & $30: 36$ \\
\hline
\end{tabular}

$0.2 \mu \mathrm{g} / \mathrm{L}$, respectively. $\mathrm{Cu}$ was detected at all sites at contents ranging from 2 to $34.9 \mathrm{mg} / \mathrm{L}$. Aquatic-life criteria for dissolved $\mathrm{Cd}, \mathrm{Pb}$, and $\mathrm{Cu}$ vary with hardness (U.S. Environmental Protection Agency, 1999), which is calculated from the $\mathrm{Ca}$ and $\mathrm{Mg}$ contents and expressed as milligrams of $\mathrm{CaCO}_{3}$ per liter (Greenberg and others, 1985).

The hardness of waters in the Fortymile River Basin ranged from 21 and to $137 \mathrm{mg} \mathrm{CaCO}_{3} / \mathrm{L}$. The $\mathrm{CCC}$ and the criteria maximum concentration (CMC, defined as the highest concentration of a material in surface water to which an aquatic community can be exposed briefly without resulting in an unacceptable effect for freshwater aquatic organisms) were calculated for each stream by using their respective hardness.
$\mathrm{Cd}$ and $\mathrm{Pb}$ contents were below both the $\mathrm{CMC}$ and $\mathrm{CCC}$ in all streams; $\mathrm{Cu}$ contents exceeded the $\mathrm{CCC}$ and $\mathrm{CMC}$ at Twin Creek, Bow Creek, Polly Creek, and Discovery Creek (fig. 6).

\section{Stream Sediment}

Trace elements in stream sediment may be contained in the sediment minerals or adsorbed onto clay, oxides, and organic layers. No State or Federal guidelines or standards exist for trace-element concentrations in stream sediment; however, the Canadian Council of Ministers for the Environment (1999) has adopted Canadian Sediment Quality Guide- 
lines for the protection of aquatic life, and guidelines have been set for $\mathrm{As}, \mathrm{Cd}, \mathrm{Cr}, \mathrm{Cu}, \mathrm{Pb}, \mathrm{Hg}$, and $\mathrm{Zn}$. Two levels are defined for the total trace-element concentration in a bulk stream-sediment sample: the interim sediment-quality guideline (ISQG), where toxicologic effects are expected to be rare; and the probable-effect level (PEL), where toxicologic effects are expected to occur (table 3).

Major- and trace-element concentrations in stream-sediment samples are listed in table 4. $\mathrm{Cd}$ and $\mathrm{Pb}$ contents are all below the ISQG, whereas $\mathrm{As}, \mathrm{Cu}, \mathrm{Hg}$, and $\mathrm{Zn}$ contents range from below to above the ISQG but below the PEL. Cr content at all sites exceeded the ISQG and at nine sites exceeded the PEL; sediment from streams draining metavolcanic rocks generally had a higher $\mathrm{Cr}$ content. To understand what, if any, effect $\mathrm{Cr}$ may be having on the aquatic biota, further work on the form and distribution of $\mathrm{Cr}$ bioavailability in this aquatic system is needed.

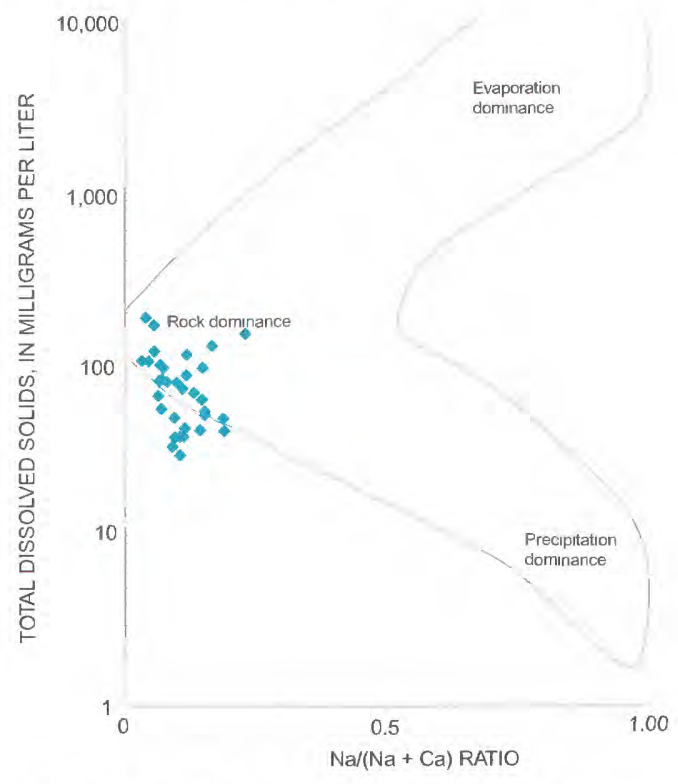

\section{Rare-Earth Elements}

Total REE concentrations range from $<0.61$ to $15 \mu \mathrm{g} / \mathrm{L}$ and from 103 to $171 \mathrm{mg} / \mathrm{kg}$ in water and stream-sediment

Figure 5. Total dissolved solids versus $\mathrm{Na}$ / $(\mathrm{Na}+\mathrm{Ca})$ ratio for the Fortymile River and its tributaries, eastern Alaska (figs. 1, 3). Boomerangshaped envelope approximated from Gibbs (1970).

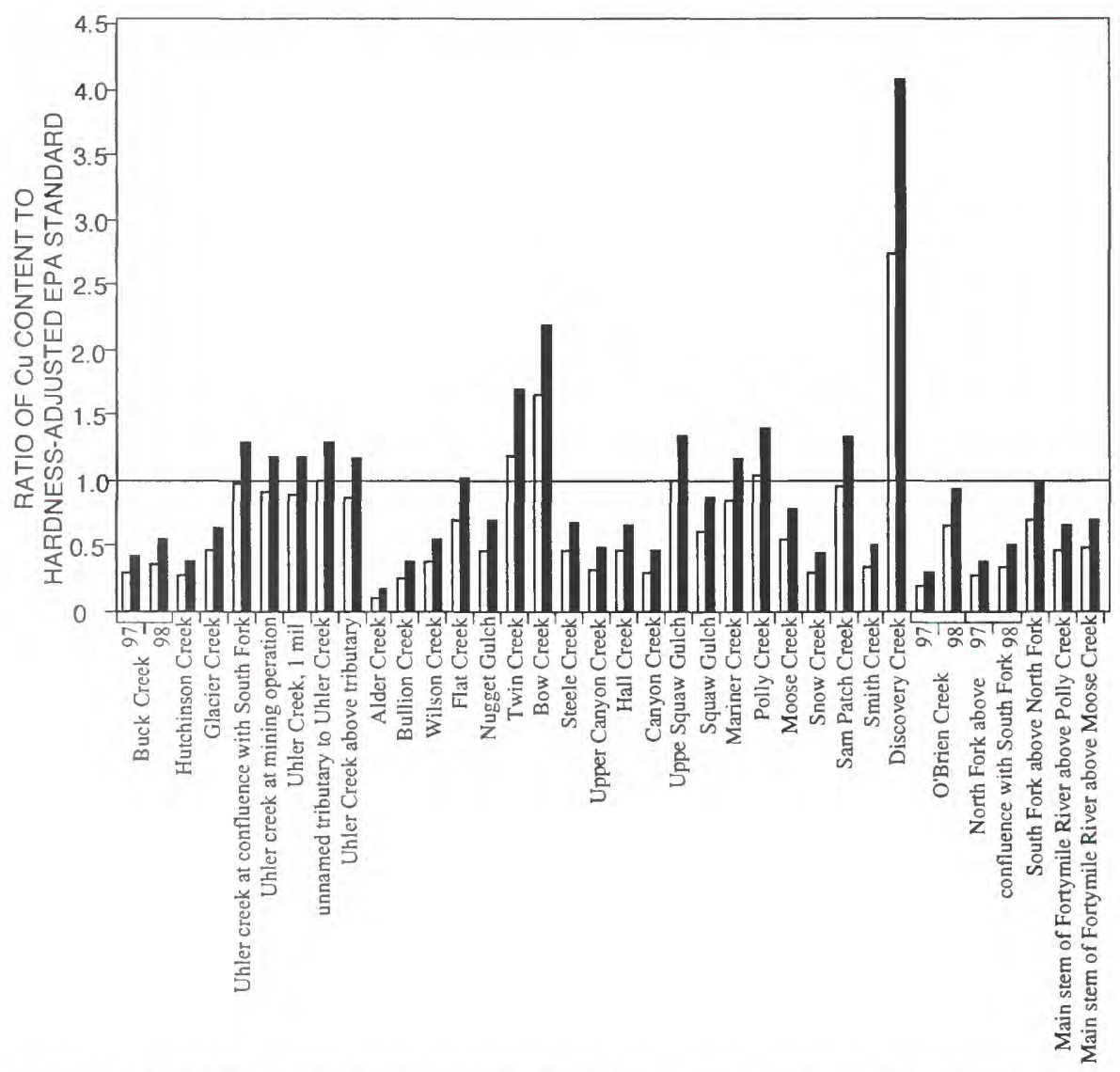

Figure 6. Ratio between filtered $\mathrm{Cu}$ contents and hardness-adjusted criteria-maximumconcentration (open bars) and criteria-continuous-concentration (solid bar) Cu standards (U.S. Environmental Protection Agency, 1999) for water samples from the Fortymile River and its tributaries, eastern Alaska. Values greater than 1 exceed hardness-adjusted standard. EPA, U.S. Environmental Protection Agency. 
samples, respectively (table 5). The REE concentrations in water samples from the Fortymile River area are generally higher than those in stream waters reported by other workers (table 6). Chondrite- and NASC-normalized patterns for water and stream-sediment samples from the Fortymile River Basin are plotted in figures 7 through 9. Both water and stream-sediment chondrite-normalized patterns are LREE enriched, with slightly negative $\mathrm{Ce}$ and Eu anomalies (figs. 7-9). The small-tributary watersheds have $(\mathrm{La} / \mathrm{Yb})_{n}$ values ranging from 3.2 to $10.9, \mathrm{Ce}^{*}$ values ranging from 0.44 to 0.97 , and $\mathrm{Eu} / \mathrm{Eu}^{*}$ values ranging from 0.44 to 0.95 in water samples, and $(\mathrm{La} / \mathrm{Yb})_{n}$ values ranging from 3.8 to $8.7, \mathrm{Ce}^{*}$ values ranging from 0.81 to 0.85 , and $\mathrm{Eu} / \mathrm{Eu}^{*}$ ratios ranging from 0.71 to 0.93 in stream-sediment samples (table 5). Water samples from the North Fork, South Fork, and main stem of the Fortymile River have $(\mathrm{La} / \mathrm{Yb})_{n}, \mathrm{Ce}^{*}$, and $\mathrm{Eu} / \mathrm{Eu}^{*}$ values in the same range as those from the tributaries (table 5). When
Table 3. Interim freshwater sediment-quality guidelines and probable-effects levels for selected trace elements in water samples from the Fortymile River and its tributaries, eastern Alaska.

[See figures 1 and 3 for locations. All values in milligrams per kilogram dry weight. ISQC, interim sediment-quality guideline (Canadian Council of Ministers for the Environment, 1999); PEL, probable-effects level]

\begin{tabular}{|c|c|c|}
\hline Element & ISQG & PEL \\
\hline As ----- & 5.9 & 17.0 \\
\hline $\mathrm{Cd}$ & .6 & 3.5 \\
\hline $\mathrm{Cr}-$ & 37.3 & 90.0 \\
\hline $\mathrm{Cu}$ & 35.7 & 197 \\
\hline $\mathrm{Pb}$ & 35.0 & 91.3 \\
\hline Hg - & .17 & .486 \\
\hline $\mathrm{Zn}-$ & 123 & 315 \\
\hline
\end{tabular}

Table 4. Summary statistics for major-ion and trace-element concentrations in stream-sediment samples from the Fortymile River and its tributaries, eastern Alaska.

[See figures 1 and 3 for locations. All values are dry-weight contents]

\begin{tabular}{|c|c|c|c|c|c|c|}
\hline Element & $\begin{array}{l}\text { Lower limit } \\
\text { of detection }\end{array}$ & $\begin{array}{l}\text { Arithmetic } \\
\text { mean }\end{array}$ & $\begin{array}{c}\text { Geometric } \\
\text { mean }\end{array}$ & $\begin{array}{l}\text { Geometric } \\
\text { deviation }\end{array}$ & $\begin{array}{l}\text { Observed } \\
\text { range }\end{array}$ & $\begin{array}{c}\text { Proportion of samples } \\
\text { above analytical } \\
\text { detection limit }\end{array}$ \\
\hline $\mathrm{Ag}(\mathrm{mg} / \mathrm{kg})$ & 0.02 & 0.34 & 0.23 & 2.38 & $0.07-1.45$ & $34: 34$ \\
\hline $\mathrm{Al}$ (wt pct) - - & .01 & 8.35 & 8.21 & 1.2 & $5.46-12$ & $34: 34$ \\
\hline As $(\mathrm{mg} / \mathrm{kg})$ - & .5 & 7.5 & 6.8 & 1.5 & $3.4-8$ & $34: 34$ \\
\hline $\mathrm{Au}(\mathrm{mg} / \mathrm{kg})$ & .005 & --- & --- & -- & $<.005-0.035$ & $24: 34$ \\
\hline $\mathrm{Ba}(\mathrm{mg} / \mathrm{kg}) \ldots$ & 5 & 1,061 & 1,051 & 1.1 & $836-1,300$ & $34: 34$ \\
\hline $\mathrm{Be}(\mathrm{mg} / \mathrm{kg})$ & .1 & 1.5 & 1.4 & 1.24 & $1-3.2$ & $34: 34$ \\
\hline $\mathrm{Bi}(\mathrm{mg} / \mathrm{kg})$-..... & .05 & 0.16 & .15 & 1.45 & $.09-0.55$ & $34: 34$ \\
\hline $\mathrm{Ca}($ wt pct) -...... & .5 & 2.8 & 2.7 & 1.3 & $1.4-5.9$ & $34: 34$ \\
\hline $\mathrm{Cd}(\mathrm{mg} / \mathrm{kg})-$ & .1 & .3 & .2 & 1.3 & $.2-0.4$ & $34: 34$ \\
\hline $\mathrm{Co}(\mathrm{mg} / \mathrm{kg})$ & 1 & 18 & 17 & 1.3 & $12-39$ & $34: 34$ \\
\hline $\mathrm{Cr}(\mathrm{mg} / \mathrm{kg})$ & .1 & 83 & 79 & 1.3 & $49-172$ & $34: 34$ \\
\hline $\mathrm{Cs}(\mathrm{mg} / \mathrm{kg}) \cdots$ & 1 & 3 & 3 & 1.3 & $2-4$ & $34: 34$ \\
\hline $\mathrm{Cu}(\mathrm{mg} / \mathrm{kg})$ & .05 & 29 & 27 & 1.4 & $19-122$ & $34: 34$ \\
\hline $\mathrm{Fe}$ (wt pct) - & .1 & 4.9 & 4.8 & 1.24 & $3.1-7.7$ & $34: 34$ \\
\hline $\mathrm{Ge}(\mathrm{mg} / \mathrm{kg}) \ldots$ & .1 & 3.0 & 2.4 & 1.1 & $1.2-6.2$ & $34: 34$ \\
\hline $\mathrm{Hg}(\mathrm{mg} / \mathrm{kg})$ & .02 & --- & --- & -- & $<.02-0.3$ & $31: 34$ \\
\hline $\mathrm{K}(\mathrm{wt}$ pct) -....... & .5 & 1.6 & 1.6 & 1.3 & $.9-2.5$ & $34: 34$ \\
\hline $\mathrm{Li}(\mathrm{mg} / \mathrm{kg})$ & .5 & 22 & 21 & 1.3 & $13-37$ & $34: 34$ \\
\hline $\mathrm{Mg}(\mathrm{wt}$ pct) -...... & .1 & 2 & 2 & 1.3 & $1.2-3.1$ & $34: 34$ \\
\hline $\mathrm{Mn}(\mathrm{mg} / \mathrm{kg})$ & 10 & 1,060 & 1,037 & 1.2 & $645-1,370$ & $34: 34$ \\
\hline Mo (mg/kg) - -...- & .1 & .9 & .9 & 1.3 & $.6-1.8$ & $34: 34$ \\
\hline $\mathrm{Na}$ (wt pct) -...... & .1 & 2.2 & 2.1 & 1.4 & $1.0-4.3$ & $34: 34$ \\
\hline $\mathrm{Nb}(\mathrm{mg} / \mathrm{kg})$ & .01 & 13 & 13 & 1.3 & $5.8-20$ & $34: 34$ \\
\hline $\mathrm{Ni}(\mathrm{mg} / \mathrm{kg}) \ldots$ & .1 & 23 & 29 & 1.5 & $12.6-88$ & $34: 34$ \\
\hline $\mathrm{Pb}(\mathrm{mg} / \mathrm{kg})$ & .1 & 16 & 15 & 1 & $9.4-28$ & $34: 34$ \\
\hline$P(w t$ pct) - & .01 & 0.1 & .09 & 1.3 & $.6-0.14$ & $34: 34$ \\
\hline $\mathrm{Rb}(\mathrm{mg} / \mathrm{kg})$ & 1 & 65 & 63 & 1 & $39-120$ & $34: 34$ \\
\hline $\mathrm{Sb}(\mathrm{mg} / \mathrm{kg})$ & .1 & 1.3 & .9 & 2.2 & $.2-5.4$ & $34: 34$ \\
\hline $\mathrm{Sc}(\mathrm{mg} / \mathrm{kg})$ & .5 & 21 & 20 & 1 & $14-33$ & $34: 34$ \\
\hline $\mathrm{Sr}(\mathrm{mg} / \mathrm{kg})$ & 10 & 282 & 270 & 1.3 & $143-558$ & $34: 34$ \\
\hline $\mathrm{Ti}(w t$ pct) $\ldots$ & .05 & 0.48 & .48 & 1.24 & $.37-0.80$ & $20: 20$ \\
\hline $\mathrm{U}(\mathrm{mg} / \mathrm{kg})$ & .05 & 2.2 & 2.1 & 1.3 & $1.4-3.6$ & $34: 34$ \\
\hline $\mathrm{V}(\mathrm{mg} / \mathrm{kg}) \ldots$ & 1 & 149 & 144 & 1.3 & $87-335$ & $34: 34$ \\
\hline $\mathrm{Y}(\mathrm{mg} / \mathrm{kg})$ & .01 & 26 & 25 & 1 & $19-46$ & $34: 34$ \\
\hline $\mathrm{Zn}(\mathrm{mg} / \mathrm{kg})-\ldots$ & 3 & 107 & 105 & 1 & $79-190$ & $34: 34$ \\
\hline
\end{tabular}


Table 5. Total rare-earth-element concentrations, $(\mathrm{La} / \mathrm{Vb})_{n}$ ratios, $\mathrm{Ce}$ anomalies $\left(\mathrm{Ce}^{*}\right)$, and $\mathrm{Eu} / \mathrm{Eu}^{*}$ ratios for water and stream-sediment samples for streams in the Fortymile River Basin, eastern Alaska.

[See figures 1 and 3 for locations. Total rare-earth-element (REE) values: tributary and Fortymile River water samples, micrograms per liter; tributary stream-sediment samples, milligrams per kilogram. $(\mathrm{La} / \mathrm{Yb})_{\mathrm{n}}=(\mathrm{La} / \mathrm{Yb})_{\text {sample }} /(\mathrm{La} / \mathrm{Yb})_{\text {standard }}(\mathrm{Goldstein}, 1988) ; \mathrm{Ce}^{*}=3(\mathrm{Ce})_{n} /\left(2 \mathrm{La} \mathrm{n}_{\mathrm{n}}+\mathrm{Nb}_{\mathrm{n}}\right)$ (Goldstein, 1988; Elderfield, 1990); $\left.\mathrm{Eu} / \mathrm{Eu}^{*}=\mathrm{Eu}_{\mathrm{n}} /\left(\mathrm{Sm}_{\mathrm{n}} \times \mathrm{Gd}_{\mathrm{n}}\right)^{0.5}(\mathrm{McLennan}, 1989)\right]$

\begin{tabular}{|c|c|c|c|c|c|c|c|}
\hline \multirow{2}{*}{ Site } & \multirow{2}{*}{$\begin{array}{l}\text { Total } \\
\text { REEs }\end{array}$} & \multicolumn{3}{|c|}{ Chondrite normalized } & \multicolumn{3}{|c|}{ NASC normalized } \\
\hline & & $(\mathrm{La} / \mathrm{Yb})_{\mathfrak{n}}$ & $\mathrm{Ce}^{*}$ & $\mathrm{Eu} / \mathrm{Eu}^{*}$ & $(\mathrm{La} / \mathrm{Yb})_{\mathrm{n}}$ & $\mathrm{Ce}^{*}$ & $\mathrm{Eu} / \mathrm{Eu}^{*}$ \\
\hline \multicolumn{8}{|c|}{ Tributaries-water } \\
\hline Alder Creek --.-- & 0.84 & 4.3 & 0.44 & 0.77 & 0.6 & 0.44 & 1.10 \\
\hline Bow Creek -.-.-. & 11.02 & 10.6 & .97 & .72 & 1.6 & .97 & 1.03 \\
\hline Bullion Creek- & 3.05 & 5.0 & .62 & .58 & .8 & .62 & .82 \\
\hline Buck Creek (1997) & 1.93 & 5.8 & .65 & .64 & .9 & .65 & .91 \\
\hline Buck Creek (1998) & 3.72 & 7.1 & .79 & .77 & 1.1 & .80 & 1.10 \\
\hline Glacier Creek- & 4.25 & 10.8 & .53 & .44 & 1.6 & .53 & .63 \\
\hline Upper Canyon Creek & 3.56 & 6.4 & .77 & .90 & 1.0 & .77 & 1.28 \\
\hline Canyon Creek - & 3.64 & 7.4 & .73 & .74 & 1.1 & .74 & 1.05 \\
\hline Discovery Creek - & 1.34 & 4.4 & .56 & .73 & .7 & .56 & 1.04 \\
\hline Flat Creek -...- & 3.83 & 8.3 & .72 & .78 & 1.2 & .72 & 1.10 \\
\hline Hall Creek - & 3.34 & 7.7 & .67 & .69 & 1.1 & .67 & .98 \\
\hline Hutchinson Creek & 2.31 & 6.5 & .60 & .66 & 1.0 & .59 & .94 \\
\hline Mariner Creek - & 12.53 & 10.9 & .93 & .67 & 1.6 & .94 & .96 \\
\hline Moose Creek - & 5.32 & 8.6 & .61 & .62 & 1.3 & .61 & .88 \\
\hline Nugget Gulch-1...- & 2.85 & 5.3 & .74 & .95 & .8 & .74 & 1.35 \\
\hline O'Brien Creek (1997) & .61 & 3.2 & .89 & .53 & .5 & .89 & .76 \\
\hline O'Brien Creek (1998) & 2.81 & 6.6 & .79 & .80 & 1.0 & .79 & 1.14 \\
\hline Polly Creek - & 9.04 & 9.5 & .90 & .77 & 1.4 & .90 & 1.09 \\
\hline Sam Patch Creek- & 4.23 & 5.0 & .86 & .78 & .7 & .86 & 1.11 \\
\hline Smith Creek & 4.33 & 6.0 & .61 & .75 & .9 & .61 & 1.07 \\
\hline Snow Creek-o.-. & 2.11 & 6.0 & .63 & .93 & .9 & .64 & 1.32 \\
\hline 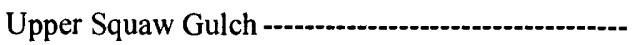 & 5.35 & 6.8 & .82 & .85 & 1.0 & .82 & 1.20 \\
\hline Squaw Gulch - & 4.28 & 6.3 & .74 & .83 & .9 & .75 & 1.19 \\
\hline Steele Creek - & 15.00 & 10.3 & .83 & .64 & 1.5 & .85 & .91 \\
\hline Twin Creek - - & 3.91 & 5.4 & .73 & .84 & .8 & .72 & 1.20 \\
\hline Uhler Creek above tributary & 3.48 & 7.9 & .73 & .60 & 1.2 & .73 & .85 \\
\hline 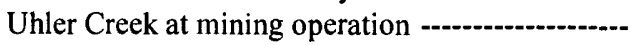 & 3.77 & 7.1 & .75 & .69 & 1.1 & .74 & .98 \\
\hline $\begin{array}{l}\text { Uhler Creek at confluence with the South Fork of } \\
\text { the Fortymile River. }\end{array}$ & 4.17 & 7.0 & .71 & .67 & 1.1 & .71 & .95 \\
\hline Uhler Creek $1 \mathrm{mi}$ above mining & 3.53 & 6.6 & .75 & .53 & 1.0 & .75 & .76 \\
\hline Unnamed tributary to Uhler Creek & 3.23 & 4.8 & .79 & .73 & .7 & .77 & 1.04 \\
\hline Wilson Creek - & 2.10 & 4.0 & .58 & .77 & .6 & .57 & 1.09 \\
\hline
\end{tabular}

Fortymile River-water

North Fork above confluence with the South Fork of the Fortymile River (1997).

North Fork above confluence with the South Fork of the Fortymile River (1998).

South Fork above confluence with the North Fork of the Fortymile River.

Main stem of the Fortymile River above Polly Creek.

Main stem of the Fortymile River below Moose Creek.

$\begin{array}{rrrrrrr}0.85 & 6.5 & 0.44 & 0.65 & 1.0 & 0.44 & 0.93 \\ 1.58 & 5.1 & .48 & .74 & .8 & .48 & 1.05 \\ 2.94 & 4.2 & .64 & .83 & .6 & .64 & 1.18 \\ 2.08 & 4.9 & .56 & .93 & .7 & .57 & 1.32 \\ 2.29 & 4.6 & .57 & .81 & .7 & .57 & 1.15\end{array}$


Table 5. Total rare-earth-element concentrations, $(\mathrm{La} / \mathrm{Yb})_{n}$ ratios, $\mathrm{Ce}$ anomalies $\left(\mathrm{Ce}{ }^{*}\right)$, and Eu/Eu* ratios for water and stream-sediment samples for streams in the Fortymile River Basin, eastern Alaska-Continued

\begin{tabular}{|c|c|c|c|c|c|c|c|}
\hline \multirow{2}{*}{ Site } & \multirow{2}{*}{$\begin{array}{l}\text { Total } \\
\text { REEs }\end{array}$} & \multicolumn{3}{|c|}{ Chondrite normalized } & \multicolumn{3}{|c|}{ NASC normalized } \\
\hline & & $(\mathrm{La} / \mathrm{Yb})_{\mathrm{n}}$ & $\mathrm{Ce}^{*}$ & $\mathrm{Eu} / \mathrm{Eu}^{*}$ & $(\mathrm{La} / \mathrm{Yb})_{\mathrm{n}}$ & $\mathrm{Ce}^{*}$ & $\mathrm{Eu} / \mathrm{Eu}^{*}$ \\
\hline \multicolumn{8}{|c|}{ Tributaries-stream sediment } \\
\hline Bow Creek - & 123.4 & 7.4 & 0.81 & 0.78 & 1.1 & 0.81 & 1.12 \\
\hline Canyon Creek & 153.4 & 7.0 & .83 & .73 & 1.0 & .83 & .73 \\
\hline Discovery Creek - & 132.3 & 5.8 & .85 & .84 & .8 & .82 & 1.20 \\
\hline Flat Creek -.... & 107.9 & 3.8 & .84 & .90 & .5 & .82 & 1.30 \\
\hline Hall Creek - & 125.6 & 5.4 & .81 & .79 & .8 & .82 & 1.12 \\
\hline Canyon Creek above Hall Creek & 124.7 & 6.4 & .81 & .81 & 1.0 & .82 & 1.16 \\
\hline 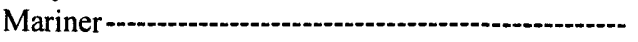 & 134.4 & 6.7 & .81 & .80 & 1.0 & .83 & 1.13 \\
\hline Canyon Creek above Mariner Creek -................. & 103.8 & 4.9 & .81 & .84 & .7 & .83 & 1.20 \\
\hline Moose Creek & 171.9 & 8.7 & .83 & .71 & 1.2 & .83 & .71 \\
\hline Nugget Creek & 132.3 & 6.5 & .82 & .79 & .9 & .81 & 1.13 \\
\hline O'Brien Creek - - & 114.1 & 5.5 & .83 & .82 & .8 & .83 & .82 \\
\hline Polly Creek & 117.4 & 6.2 & .83 & .83 & .9 & .82 & .83 \\
\hline Sam Patch Creek - & 107.1 & 5.9 & .83 & .86 & .8 & .83 & .86 \\
\hline Smith Creek - & 150.8 & 7.6 & .82 & .75 & 1.1 & .82 & .75 \\
\hline Snow Creek-1- & 124.1 & 6.7 & .83 & .84 & 1.0 & .83 & .84 \\
\hline Upper Squaw Creek - & 122.0 & 5.8 & .84 & .87 & .8 & .84 & .87 \\
\hline Squaw Creek & 111.8 & 4.4 & .82 & .93 & .7 & .83 & 1.32 \\
\hline Canyon Creek above Squaw & 121.0 & 5.7 & .82 & .78 & .8 & .83 & 1.11 \\
\hline Steele Creek -...- & 136.8 & 6.9 & .82 & .78 & 1.0 & .82 & 1.12 \\
\hline Twin Creek --1- & 120.9 & 5.6 & .82 & .86 & .8 & .80 & 1.23 \\
\hline
\end{tabular}

water and stream-sediment samples are normalized to the NASC, the resulting patterns range from no REE fractionation to LREE enrichment or depletion; the NASC-normalized patterns also have negative $\mathrm{Ce}$ and negative to positive $\mathrm{Eu}$ anomalies (figs. 7-9; table 4).

In rivers, colloidal matter and solution $\mathrm{pH}$ have been observed to affect both the aqueous REE concentrations and normalized patterns (Goldstein and Jacobsen, 1988; Elderfield and others, 1990; Sholkovitz, 1992). Filtering through progressively smaller pore-size filters resulted in progressively more LREE depletion in the filtrate (Elderfield, 1990; Sholkovitz,1992, 1995; Ingri, 2000). In general, REEs in river water appear to fractionate between the colloidal and dissolved phases to produce an LREE-enriched colloidal phase and an LREE-depleted dissolved phase, with total REE concentrations dominated by the colloidal fraction. The colloidal fraction may be composed of organic matter, $\mathrm{Fe}$ oxyhydroxides, and (or) organically stabilized Al or Fe oxide (Ingri, 2000). When the total REE concentration is plotted against the $\mathrm{Fe}+\mathrm{Al}$ contents, a linear relation is obtained (fig. 10), as if $\mathrm{Fe}+\mathrm{Al}$ contents indicate the colloid concentration remaining in the filtrate. Furthermore, these waters are supersaturated with respect to amorphous $\mathrm{Fe}$ oxyhydroxides, and the $\mathrm{Fe}$ is most likely present as an oxyhydroxide or an organically stabilized Fe-containing colloid (Langmuir, 1997; Ingri, 2000). There- fore, $\mathrm{Fe}+\mathrm{Al}$ contents are used here as a proxy measure for colloidal matter.

The four creeks (Steele, Mariner, Bow, and Polly) with the highest REE and colloid concentrations drain the Steele Creek Dome orthogneiss. Differences in the REE concentrations of 1997 and 1998 samples can be explained by higher colloid concentrations in the 1998 samples relative to those collected in 1997. In 1998, the total REE and colloid concentrations of the South Fork were about twice those of the North Fork. Downstream concentrations on the main stem of the Fortymile River fell linearly between these two values $\left(Y=0.005+0.532, R^{2}=0.984\right.$; fig. 10$)$. The differences in colloid concentrations appear to explain the difference in total REE concentrations between the North and South Forks and within the main stem of the river.

Colloid concentration also appears to influence $\mathrm{Ce}^{*}$ values (fig. 11). Consistent with the effects of colloidal matter on the Ce anomaly observed by other workers (Ingri, 2000), the most pronounced negative $\mathrm{Ce}$ anomalies were observed in samples with the lowest colloid concentrations. In contrast, $\mathrm{pH}$ did not affect either REE concentrations or Ce anomaly (fig. 10). Neither colloid concentration nor $\mathrm{pH}$ appeared to influence the $\mathrm{Eu} / \mathrm{Eu}^{*}$ or $(\mathrm{La} / \mathrm{Yb})_{\mathrm{n}}$ ratio (fig. 12). No relation was noted between $\mathrm{Fe}$ or $\mathrm{Fe}+\mathrm{Al}$ content and total REE concentrations in stream sediment. 


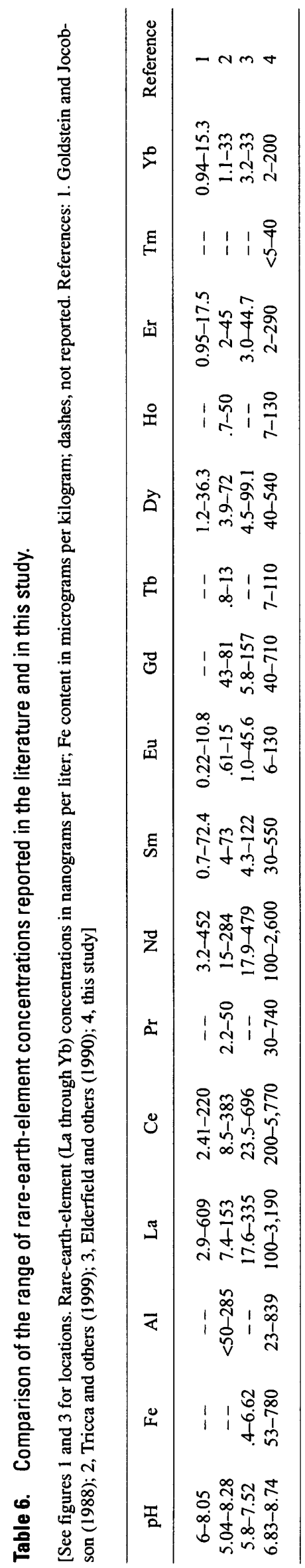
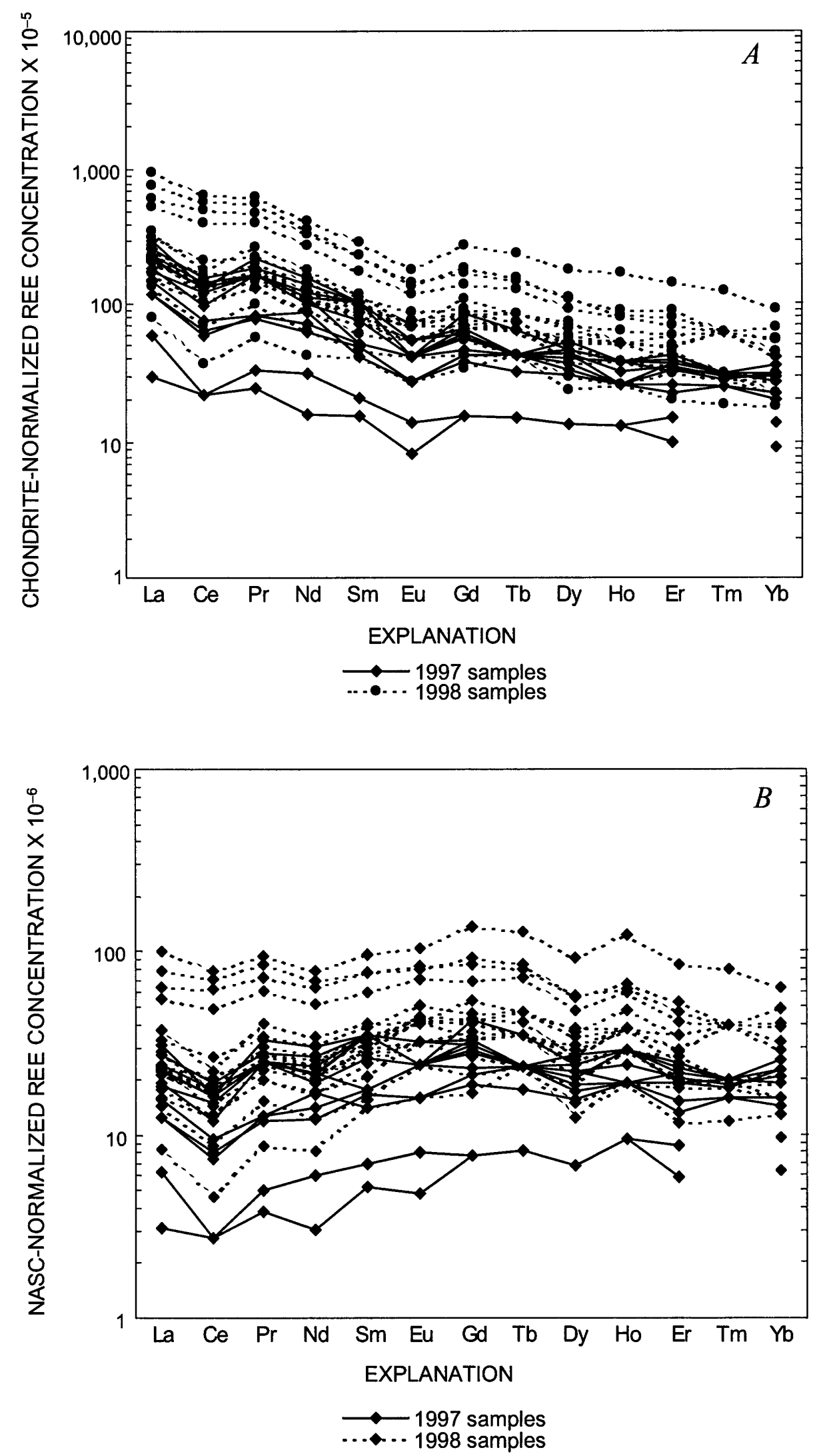

Figure 7. Rare-earth-element (REE) concentrations in water samples collected from small tributaries in the Fortymile River Basin (fig. 3), normalized to chondrite $(A)$ and the North American Shale Composite (NASC) (B). 

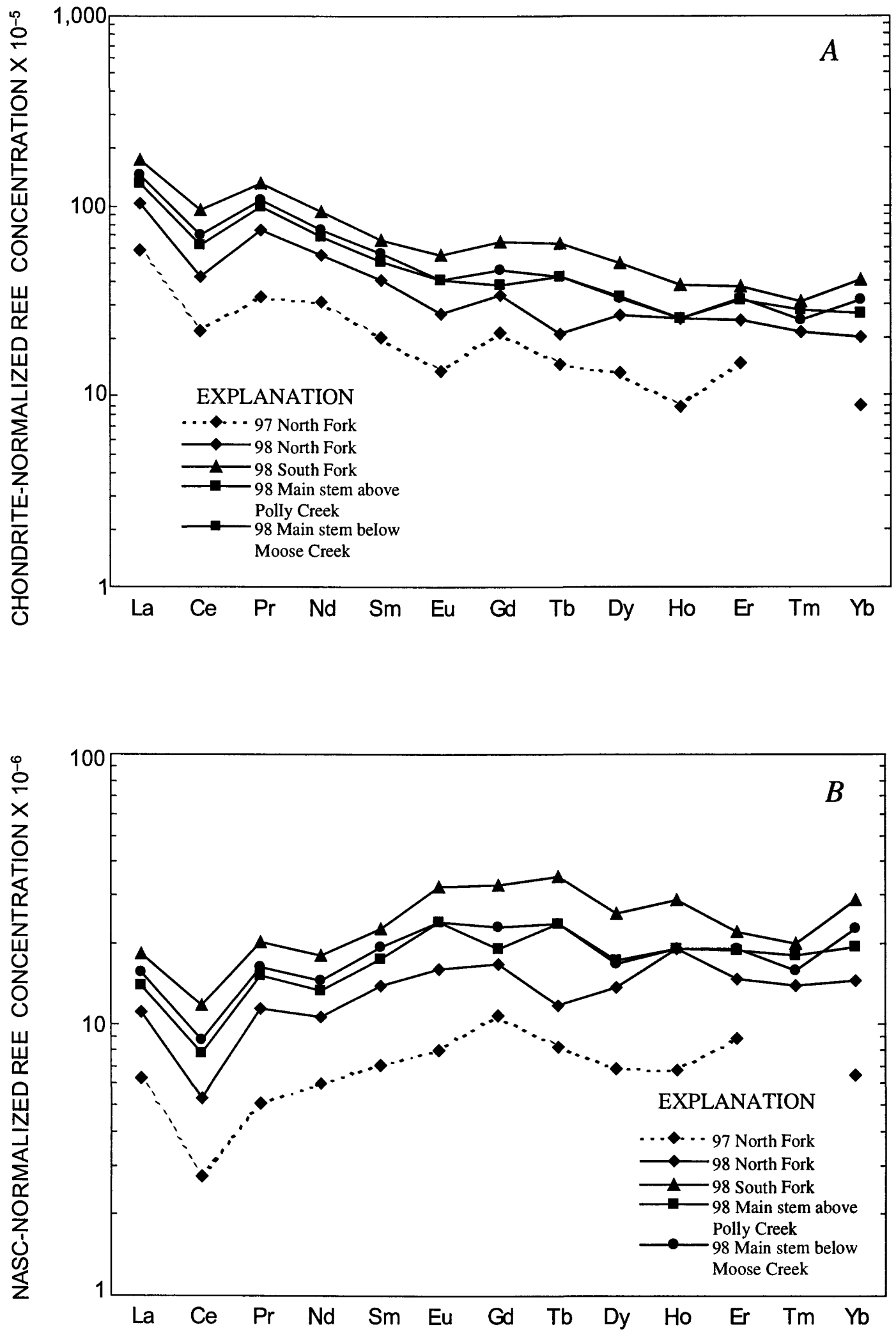

Figure 8. Rare-earth-element (REE) concentrations in water samples collected from the North Fork, South Fork, and main stem of the Fortymile River normalized to chondrite $(A)$ and the North American Shale Composite (NASC) (B). 

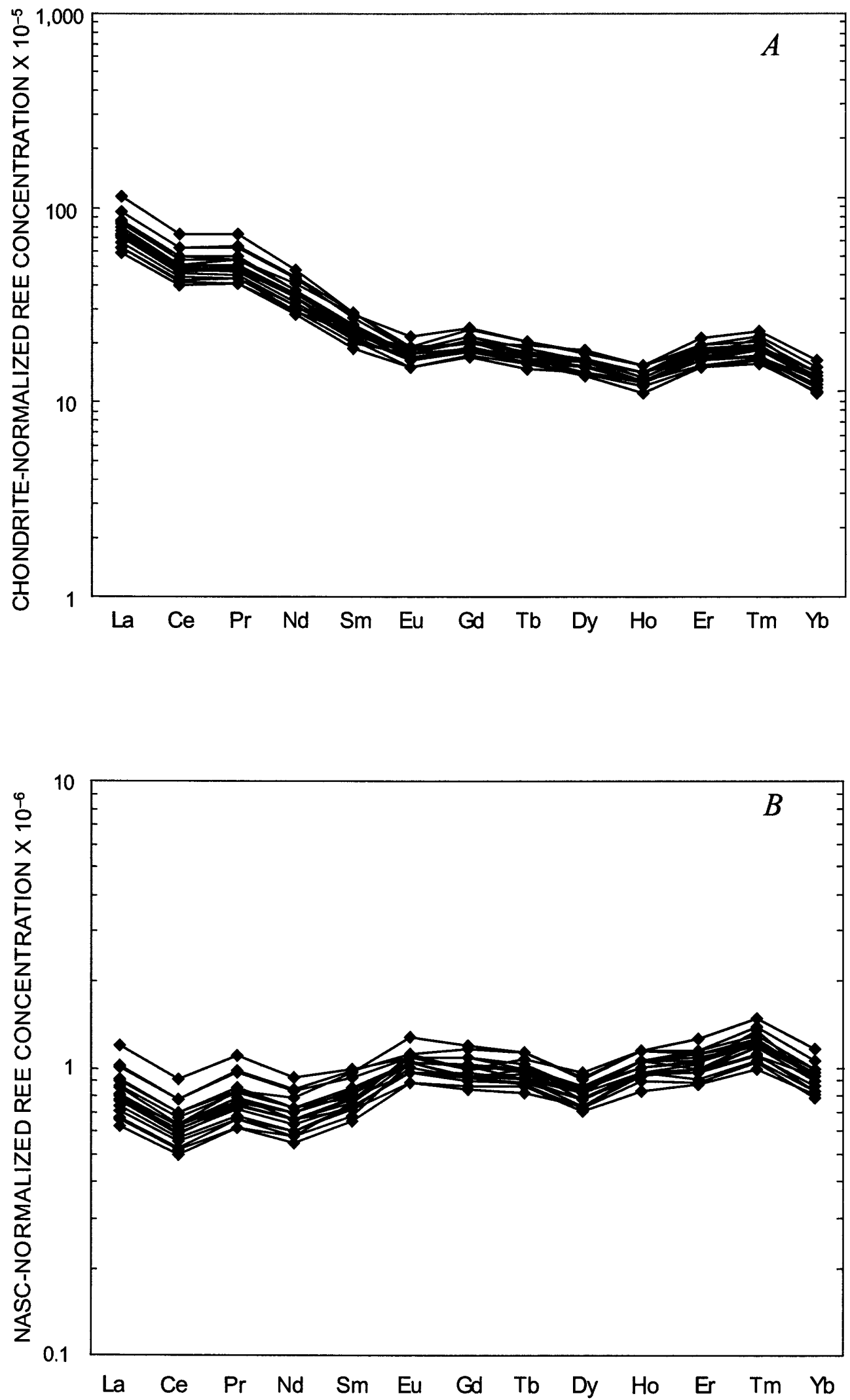

Figure 9. Rare-earth-element (REE) concentrations in stream-sediment samples from the Fortymile River Basin, eastern Alaska (figs. 1,3), normalized to chondrite $(A)$ and the North American Shale Composite (NASC) (B). 

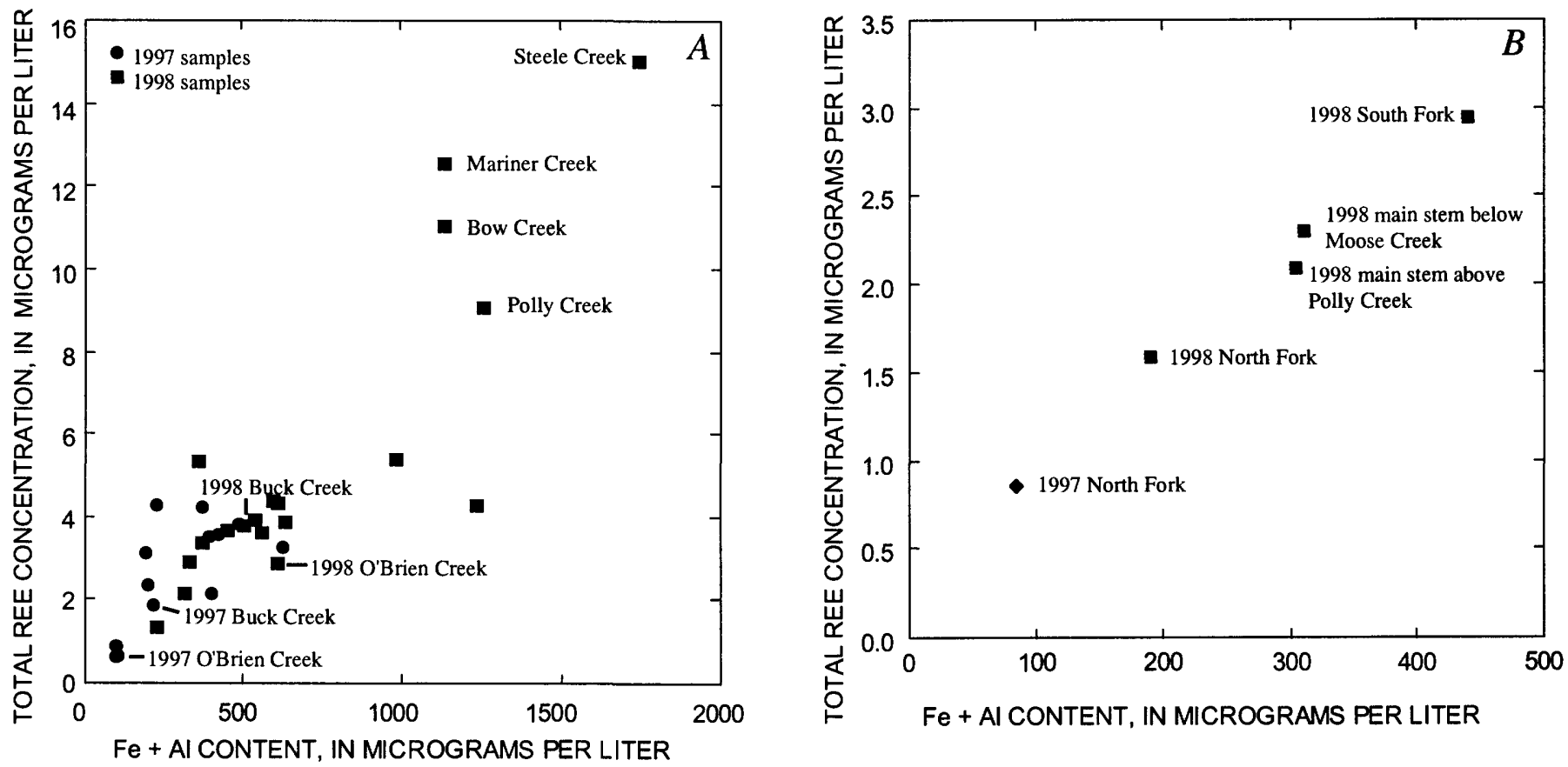

Figure 10. Total rare-earth-element (REE) concentration versus Fe+Al content in water samples from small tributaries $(A)$ and the Fortymile River (B), eastern Alaska (figs. 1,3).

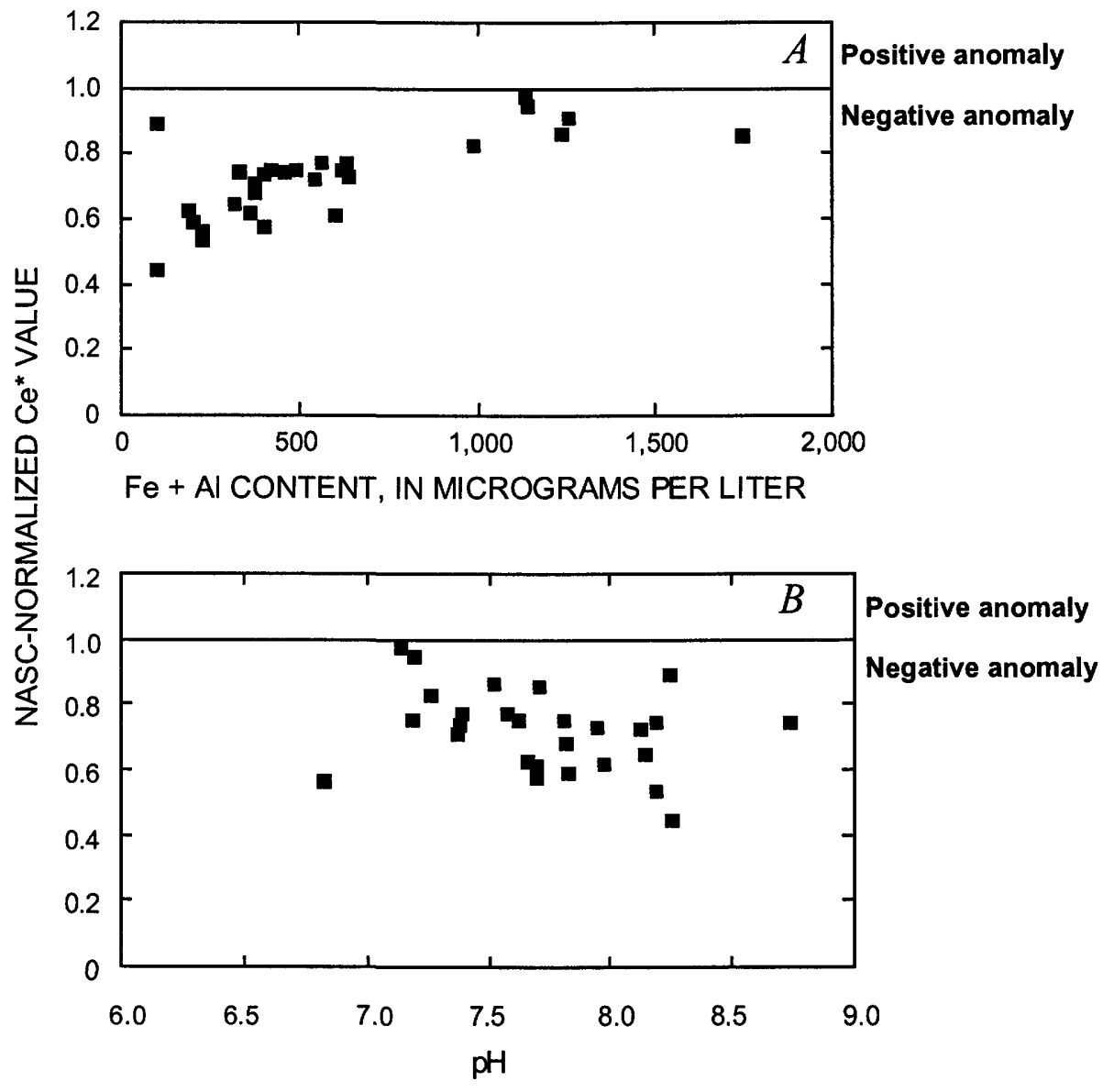

Figure 11. Sensitivity of $\mathrm{Ce}$ anomaly $\left(\mathrm{Ce}^{*}\right)$ to colloidal matter ( $\mathrm{Fe}+\mathrm{Al}$ content) and $\mathrm{pH}$ in water samples collected from the Fortymile River Basin, eastern Alaska (figs. 1, 3). NASC, North American Shale Composite. 

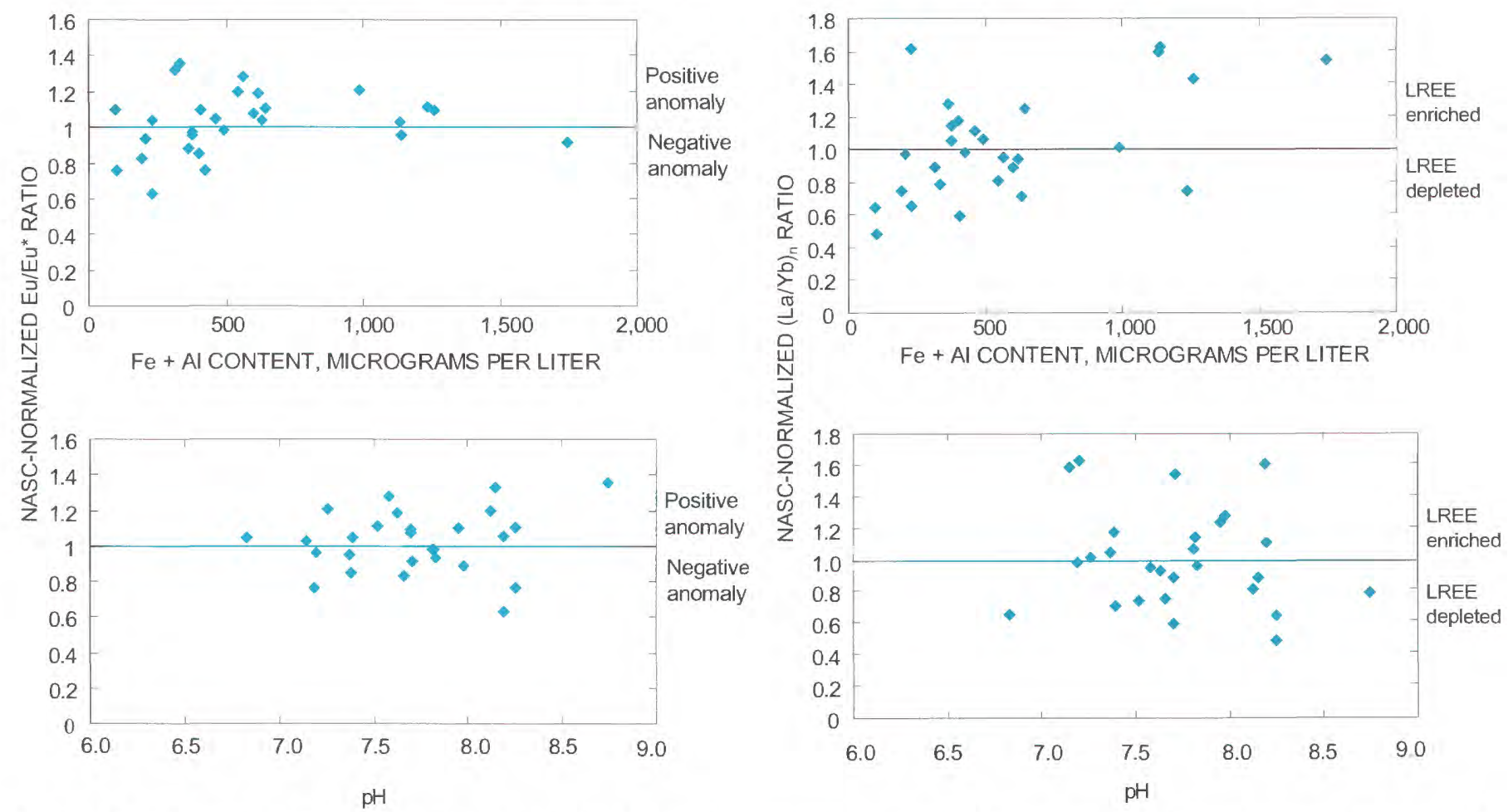

Figure 12. Sensitivity of Eu anomaly (Eu/Eu*) and $(\mathrm{La} / \mathrm{Yb})_{n}$ ratio to colloidal matter ( $\mathrm{Fe}+\mathrm{Al}$ content) and $\mathrm{pH}$ in water samples collected from the Fortymile River Basin, eastern Alaska (figs. 1, 3). NASC, North American Shale Composite.

\section{Summary}

The waters of the Fortymile River and its tributaries are classified primarily as $\mathrm{Ca}^{2+}$ and $\mathrm{Mg}^{2+}-\mathrm{HCO}_{3}^{-}$to mixed $\mathrm{Ca}^{2+}$ and $\mathrm{Mg}^{2+}-\mathrm{HCO}_{3}^{-}$and $\mathrm{SO}_{4}^{2-}$ type. Trace-element concentrations are generally low except for $\mathrm{Cu}$ content, which commonly exceeds aquatic-life standards for both short (CMC) and indefinite (CCC) exposure. Trace-element concentrations of regulatory concern were detectable in stream-sediment samples, but only the $\mathrm{Cr}$ content appears to be elevated relative to the Canadian standards for stream sediment. Development in the basin is limited, and the elevated $\mathrm{Cr}$ content most likely represents a natural signature that reflects the presence of metavolcanic rocks. The extent to which the $\mathrm{Cr}$ content may or may not affect aquatic biota is uncertain because no information is available on the $\mathrm{Cr}$ bioavailability in this aquatic system. Such bioavailability partly depends on the elemental form.

Total REE concentrations in water samples from the Fortymile River Basin range from $<0.61$ to $15 \mu \mathrm{g} / \mathrm{L}$ and are generally higher than those reported by workers elsewhere. The strong association observed between total REE concentrations and $\mathrm{Fe}+\mathrm{Al}$ content may point to the influence of colloid concentrations on chemical transport. Other workers have reported decreases in both $\mathrm{Ce}^{*}$ value and $(\mathrm{La} / \mathrm{Yb})_{11}$ ratio with decreasing colloid concentration, indicating Ce depletion and LREE enrichment in the colloidal matter (Elderfield, 1990; Sholkocitz, 1992, 1995; Ingri, 2000). Consistent with these results, a more negative $\mathrm{Ce}^{*}$ anomaly was correlated with decreasing colloid concentration; however, no effect was observed on $(\mathrm{La} / \mathrm{Yb})_{n}$ ratio. The absence of an observed association between $(\mathrm{La} / \mathrm{Yb})_{n}$ ratio and colloid concentration may indicate the dominance of colloidal matter to such an extent that the LREE-depleted dissolved component in the aquatic system was not observed.

\section{References Cited}

Banks, D.A., Hall, G.E.M., Reimann, Clemens, and Siewers, Ulrich, 1999, Distribution of rare earth elements in crystalline bedrock groundwaters; Oslo and Bergen regions, Norway: Applied Geochemistry, v. 14, no. 1, p. 27-39.

Brookins, D.G., 1989, Aqueous geochemistry of rare earth element, in Lipin, B.R., and McKay, G.A., eds., Geochemistry and mineralogy of rare earth elements (Reviews in Mineralogy, v. 21): Washington, D.C., Mineralogical Society of America, p. 201-223.

Canadian Council of Ministers of the Environment, 1999, Canadian environmental quality guidelines; Canadian sediment quality guidelines for the protection of aquatic life-summary tables, in Canadian environmental quality guidelines, 1999: Winnipeg, Manitoba.

Crock, J.G., Gough, L.P., Wanty, R.B., Day, W.C., Wang, Bronwen, Gamble, B.M., Henning M.W., Brown, Z.A., and 
Meier, A.L., 1999, Regional geochemical results from the analyses of rock, water, soil, stream sediment, and vegetation samples-Fortymile River watershed, east-central Alaska: U.S. Geological Survey Open-File Report 99-33, 82 p.

Crock, J.G., Gough, L.P., Wanty, R.B., Day, W.C., Wang, Bronwen, Gamble, B.M., Henning M.W., Brown, Z.A., and Meier, A.L., 2000, Regional geochemical results from the analyses of rock, water, soil, stream sediment, and vegetation samples-Fortymile River watershed, east-central Alaska, 1998 sampling: U.S. Geological Survey Open-File Report 00-511, $157 \mathrm{p}$.

Cullers, R.L., Barrett, Terry, Carlson, Randy, and Robinson, Bob, 1987, Rare-earth element and mineralogic changes in Holocene soil and stream sediment; a case study in the Wet Mountains, Colorado, U.S.A.: Chemical Geology, v. 63, no. 3-4, p. 275-297.

Day, W.C., Aleinikoff, J.N., and Gamble, B.C., 2002, Geochemistry and age constraints on metamorphism and deformation in the Fortymile River area, eastern Yukon-Tanana Upland, Alaska, in Wilson, F.H., and Galloway, J.P., eds., Studies by the U.S. Geological Survey in Alaska, 2000: U.S. Geological Survey Professional Paper 1662, p. 5-18.

Day, W.C., Gamble, B.C., Henning, M.W., and Smith, B.D., 2000, Geologic setting of the Fortymile River area; polyphase deformational history within part of the eastern Yukon-Tanana uplands of Alaska, in Kelley, K.D., and Gough, L.P., eds., Geologic studies in Alaska by the U.S. Geological Survey, 1998: U.S. Geological Survey Professional Paper 1615, p. 65-81.

Dusel-Bacon, Cynthia, and Cooper, K.M., 1999, Trace-element geochemistry of metabasaltic rocks from the YukonTanana upland and implications for the origin of tectonic assemblages in east-central Alaska: Canadian Journal of Earth Sciences, v. 36, no. 10, p. 1671-1695.

Dusel-Bacon, Cynthia, Hansen, V.L., and Scala, J.A., 1995, High-pressure amphibolite facies dynamic metamorphism and the Mesozoic tectonic evolution of an ancient continental margin, east-central Alaska: Journal of Metamorphic Geology, v. 13, no. 1, p. 9-24.

Elderfield, Henry, Upstill-Goddard, R.C., and Sholkovitz, E.R., 1990, The rare earth elements in rivers, estuaries, and coastal seas and their significance to the composition of ocean water: Geochimica et Cosmochimica Acta, v. 54, no. 4, p. 971-991.

Fishman, M.J., and Pyen, G.S., 1979, Determination of selected anions in water by ion chromatography: U.S. Geological Survey Water-Resources Investigations Report PB-80 11941, 36 p.

Foster, H.L., Keith, T.E.C., and Menzie, W.D., 1994, Geology of the Yukon-Tanana area of east-central Alaska, in Plafker,
George, and Berg, H.C., eds., The geology of Alaska, v. G-1 of The geology of North America: Boulder, Colo., Geological Society of America, p. 205-240.

Gamble, B.C., Day, W.C., and Henning, M.W., 2001, Geochemistry of lithologic units, Fortymile River study area, east-central Alaska, in Gough, L.P., and Wilson, F.W., eds., Geologic studies in Alaska by the U.S. Geological Survey, 1999: U.S. Geological Survey Professional Paper 1633, p. 127-134.

Gibbs, R.J., 1970, Mechanisms controlling world water chemistry: Science, v. 170, no. 3962, p. 1088-1090.

Goldfarb, R., Hart, C., Miller, M., Miller, L. Farmer, G.L. and Grovesy, D., 2000, The Tintina Gold Belt-a global perspective, in Tucher, T.L., and Smith, Moria, eds., The Tintina Gold Belt; concepts, exploration, and discoveries; British Columbia and Yukon Chamber of Mines Cordilleran Roundup, January 2000, p. 5-34.

Goldstein, S.J., and Jacobsen, S.B., 1988, Rare earth elements in river waters: Earth and Planetary Science Letters, v. 89, no. 1, p. 35-47.

Gough, L.P., Crock, J.G., Day, W.C., and Vohden, Jim, 2001, Biogeochemistry of arsenic and cadmium, Fortymile River watershed east-central Alaska, in Gough, L.P., and Wilson, F.W., eds., Geologic studies in Alaska by the U.S. Geological Survey, 1999: U.S. Geological Survey Professional Paper 1633, p. 109-126.

Greenberg, A.E., Trussell, R.R., and Clesceri, L.S., 1985, Standard methods for the examination of water and wastewater (16th ed.): Baltimore, Port City Press, 1,268 p.

Greenwood, N.N., and Earnshaw, Alan, 1984, Chemistry of the elements: Oxford, U.K., Pergamon Press, 1,543 p.

Hansen, V.L., and Dusel-Bacon, Cynthia, 1998, Structural and kinematic evolution of the Yukon-Tanana upland tectonites, east-central Alaska - a record of late Paleozoic to Mesozoic crustal assembly: Geological Society of America Bulletin, v. 110 , no. 2, p. 211-230.

Ingri, Johan, Widerlund, Auders, Land, Magnus, Gustafsson, Orjan, Anderson, Per, and Ohlander, Bjorn, 2000, Temporal variations in the fractionation of the rare earth elements in a boreal river; the role of colloidal particles: Chemical Geology, v. 166, no. 1-2, p. 23-45.

Johannesson, K.H., Stetzenbach, K.J., and Hodge, V.F., 1997, Rare earth elements as geochemical tracers of regional groundwater mixing: Geochimica et Cosmochimica Acta, v. 61 , no. 17, p. 3605-3618.

Johannesson, K.H., Zhou, Xiaoping, Guo, Caixia, Stetzenback, K.J., and Hodge, V.F., 2000, Origin of rare earth element signatures in groundwaters of circumneutral $\mathrm{pH}$ from Nevada and eastern California, USA: Chemical Geology, v. 164 , no. 3-4, p. 239-257. 
Keasler, K.M., and Loveland, W.D., 1982, Rare earth elemental concentrations in some Pacific Northwest rivers: Earth and Planetary Science Letters, v. 61, no. 1, p. 68-72.

Langmuir, Donald, 1997, Aqueous environmental geochemistry: Upper Saddle River, N.J., Prentice Hall, 600 p.

Lichte, F.E., Golightly, D.W., and Lamothe, P.J., 1987, Inductively coupled plasma-atomic emission spectrometry, in Baedecker, P.A. ed., Methods for geochemical analysis: U.S. Geological Survey Bulletin 1770, p. B1-B10.

McLennan, S.M., 1989, Rare earth elements in sedimentary rocks: Influence of province and sedimentary processes, in Lipin, B.R., and McKay, G.A., eds., Geochemistry and mineralogy of rare earth elements (Reviews in Mineralogy, $v$. 21): Washington, D.C., Mineralogical Society of America, p. $169-200$.

Meier, A.L., Grimes, D.J., and Ficklin, W.H., 1994, Inductively coupled plasma mass spectrometry; a powerful analytical tool for mineral resource and environmental studies, in Carter, L.M.H., Toth, M.I., and Day, W.C., eds., USGS research on mineral resources, 1994; part A. Program and abstracts: U.S. Geological Survey Circular 1103-A, p. 67-68.

Mertie, J.B., Jr., 1938, Gold placers of the Fortymile, Eagle, and Circle districts, Alaska: U.S. Geological Survey Bulletin 897-C, p. 133-261.

Morey, G.B., and Setterholm, D.R., 1997, Rare earth elements in weathering profiles and sediments of Minnesota; implications for provenance studies: Journal of Sedimentary Research, v. 67 , no. 1 , p. 105-115.

Ohlander, Bjorn, Land, Magnus, Ingri, Johan., and Widerlund, Anders, 1996, Mobility of rare earth elements during weathering of till in northern Sweden: Applied Geochemistry, v. 11 , no. 1-2, p. 93-99.

Sholkovitz, E.R., 1992, Chemical evolution of rare earth elements; fraction between colloidal and solution phases of filtered river water: Earth and Planetary Science Letters, v. 114 , no. 1, p. 77-84.

Sholkovitz, E.R., 1995, The aquatic chemistry of rare earth elements in rivers and estuaries: Aquatic Geochemistry, v. 1, no. 1, p. 1-34.

Smedley, P. L., 1991, The geochemistry of rare earth elements in groundwater from the Carnmenellis area, southwest England: Geochimica et Cosmochimica Acta, v. 55, no. 10, p. 2767-2779.
Szumigala, D.J., Newberry, R.J., Werdon, M.B., Finseth, B.A., and Pinney, D.S., 2000a, Preliminary geologic map of a portion of the Fortymile Mining District, Alaska, 1999: Alaska Division of Geological and Geophysical Surveys Preliminary Interpretive Report 2000-6, scale 1:63,360.

Szumigala, D.J., Newberry, R.J., Werdon, M.B., Finseth, B.A., Pinney, D.S., and Flynn, R.L., 2000b, Major-oxide, minor-oxide, trace-element, and geochemical data from rocks collected in a portion of the Fortymile mining district, Alaska, 1999: Alaska Division of Geological and Geophysical Surveys Raw Data File 2000-1, 26 p., 2 sheets, scale 1: 63,360 .

Tricca, Aude, Stille, Peter, Steinmann, Marc, Kiefel, Bernard, Samuel, Jean, Eikenberg, Jost, 1999, Rare earth elements and $\mathrm{Sr}$ and $\mathrm{Nd}$ isotopic compositions of dissolved and suspended loads from small river systems in the Vosges Mountains (France), the river Rhine and groundwater: Chemical Geology, v. 160, no. 1-2, p. 139-158.

U.S. Environmental Protection Agency, 1999, National recommended water quality criteria-corrections: Report EPA822-Z-99-001, 25 p.

Wanty, R.B., Wang, Bronwen, Vohden, Jim, Briggs, P.H., and Meirer, A.L., 2000, Regional baseline geochemistry and environmental effects of gold placer mining operations on the Fortymile River, eastern Alaska, in Kelley, K.D., and Gough, L.P., eds., Geologic studies in Alaska by the U.S. Geological Survey, 1998: U.S. Geological Survey Professional Paper 1615, p. 101-110.

Wood, S.A., 1990, The aqueous geochemistry of the rare-earth elements and yttrium. 1. Review of available low-temperature data for inorganic complexes and the inorganic REE speciation of natural waters: Chemical Geology, v. 82, no. 1-2, p. 159-186.

Wood, W.W., 1976, Guidelines for the collection and field analysis of ground-water samples for selected unstable constituents: U.S. Geological Survey Techniques of WaterResources Investigations Report TWRI 01-D2, 24 p.

Worrall, Fred, and Pearson, D.G., 2001, The development of acidic groundwater in coal-bearing strata; part I. Rare earth element fingerprinting: Applied Geochemistry, v. 16, no. 13, p. $1465-1480$.

Yeend, Warren, 1996, Gold placers of the historical Fortymile River region, Alaska: U.S. Geological Survey Bulletin 2125, $75 \mathrm{p}$. 



\title{
Chapter 2
}

\section{Biogeochemistry, Stable-Isotopic Composition, and Feeding Habits of Arctic Grayling (Thymallus arcticus) in the Lower Fortymile River, Eastern Alaska}

\author{
By Larry P. Gough, James G. Crock, Robert R. Seal, Bronwen Wang, and Phyllis Weber-Scannell'
}

\section{Contents}

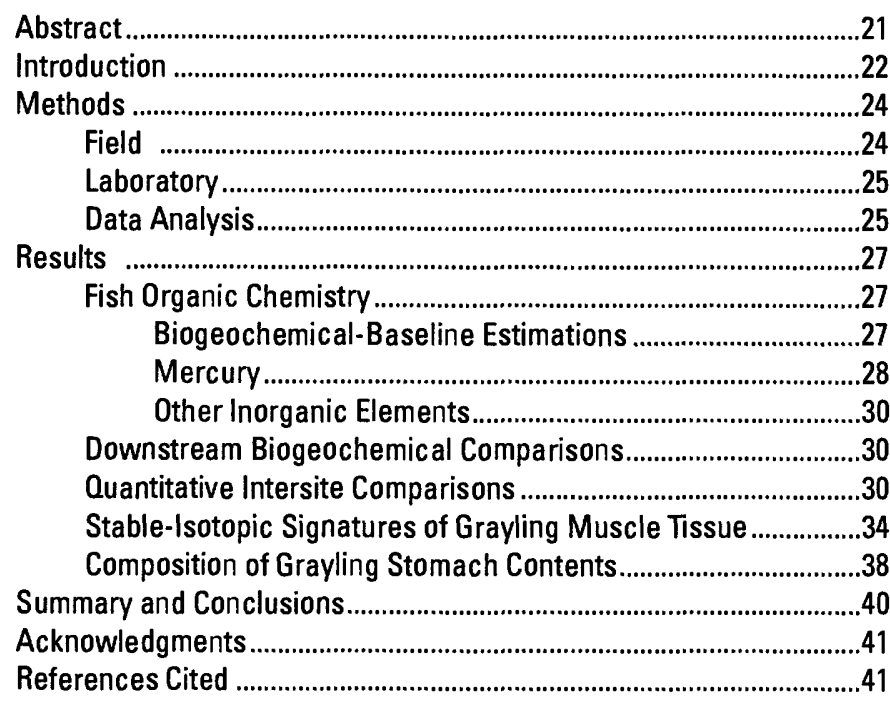

\section{Abstract}

We report on the inorganic chemistry of Arctic grayling, an ecologically important resident freshwater sport and subsistence fish in the Fortymile Mining District of the Interior Highlands Ecoregion in eastern Alaska. Placer gold has been mined in the study area for more than a century and mineral exploration activity is currently being renewed there. We report functional biogeochemical baseline values and (or) ranges for 38 elemental concentrations in muscle (fillet) tissue, liver tissue, and stomach contents from 34 fish caught at 11 sampling sites within the watershed. Included in these data are geometric means for total $\mathrm{Hg}$ contents of 0.069 and $0.062 \mathrm{ppm}$

${ }^{1}$ Alaska Department of Fish and Game. in muscle and liver tissue, respectively. These levels are more than an order of magnitude below the Food and Drug Administration's permissible value for methylmercury in fish fillets.

This study does not attempt to correlate fish age (weight) with tissue chemistry (we sampled only sexually mature fish); however, biogeochemical variation in association with fish age nevertheless occurs. For example, we found a positive correlation $\left(r^{2}=0.41\right)$ between the total $\mathrm{Hg}$ content in muscle tissue and fish weight.

Because we are most interested in the relation between elemental concentrations in fish tissue and regional geochemistry (as influenced by the geochemistry of lithologic units), we normalized tissue elemental concentrations to fish weight. In general, we noted little variation in the normalized elemental concentrations in muscle tissue among samples at each of the 11 fish-sampling sites. No definitive link could be attributed between biogeochemical patterns and regional lithology. Differences among fish-sampling sites (as determined by an unpaired $t$ test), however, were important for a few major nutrient elements (Ca, K, Mg, Na, P) and trace elements (Cr, Cs, Hg, Se). Stomach-content chemistry, also normalized to fish weight, varied widely (relative to liver or muscle tissue) and generally reflected sediment chemistry-a component of the ingested material. The $\mathrm{N}$-isotopic compositions of fillet samples are homogeneous $\left(\delta^{15} \mathrm{~N}=7.6-9.7\right.$ permil), reflecting a restricted, low trophic (primary predator) position for the grayling. C- and S-isotopic compositions $\left(\delta^{13} \mathrm{C}, \delta^{34} \mathrm{~S}\right.$ values) of fillet samples range from -33.1 to -25.8 permil and from -8.4 to 8.2 permil, respectively, suggesting heterogeneity of food sources (both aquatic and terrestrial).

Stomach-content material was examined for the occurrence and frequency of macroinvertebrates and their chemical composition in three fish. Results showed considerable diversity, with 9 to 15 invertebrate taxa of which both aquatic and terrestrial forms were represented. 


\section{Introduction}

Arctic grayling (Thymallus arcticus) is an ecologically important, nonanadromous ${ }^{3}$ (resident) salmonid fish that inhabits streams in the subarctic and Arctic regions of North America and Europe (Reynolds, 1997). Although several studies have examined the effect of mining on grayling habitat and physiologic health (for example, Reynolds and others, 1989), few data are available on the major- and trace-element content in grayling tissue or on the possible link between regional geochemical signatures (as defined by lithologic units) and fish chemistry. Farrell and others (2000) analyzed individual scales from grayling collected in eastern Alaska and correlated their metallic-ion contents with those in muscle tissue; they did not, however, relate metallic-ion contents to geochemistry. Gray and others $(1996,2000)$ reported on the relation between the $\mathrm{Hg}$ content (both inorganic and organic forms) in grayling and the geochemistry of surface water and stream sediment in a region of $\mathrm{Hg}$ mineralization and abandoned $\mathrm{Hg}$ mines in southwestern Alaska. The Alaska Department of Fish and Game and the U.S. Fish and Wildlife Service have more than 10 years of data (both published and unpublished) on traceelement contents in surface water, sediment, and grayling (and other fish species) from various sites in interior Alaska (Snyder-Conn and others, 1992; Mueller and others, 1996).

This study focuses on the chemistry of Arctic grayling collected within the Fortymile River in eastern Alaska (fig. 1), whose basin has been mined for placer gold since the late 1880 's. Recently, mineral-exploration activity has been renewed in the study area; however, lode-deposit mining is not currently being conducted in the basin.

Understanding the relation between fish chemistry and the geochemistry of surface water, stream sediment, and local lithologic units is essential for establishing baseline biogeochemical values for this and other aquatic organisms in areas that are both mineralized and nonmineralized. Stable-isotopic analyses (for the elements $\mathrm{N}, \mathrm{C}$, and $\mathrm{S}$ ) of muscle tissue have been used extensively to help explain the trophic level that most closely characterizes the feeding habits of the fish (DeNiro and Epstein, 1978, 1981; Minagawa and Wada, 1984; Peterson and Fry, 1987; Hobson, 1999). Questions that can be addressed with stable-isotopic data on fish tissue (coupled with diet information determined from stomach-content analysis) include definition of the mixture of vegetative versus invertebrate material in the diet (trophic or feeding level within the food web), definition of aquatic versus terrestrial sources of the invertebrates, and definition of the sources of trace elements that may be bioavailable in the diet. All of these questions are important because they assist in explaining possible relations between the trace-element contents in fish muscle tissue and the underlying geology.

The life history and physiological ecology of grayling in North America have been extensively studied (for example,

\footnotetext{
${ }^{3}$ Nonanadromous fish are those that do not possess a sea run as part of their life history.
}

West and others, 1992; Deegan and others, 1997; Reynolds, 1997). Grayling inhabit clearwater streams, where, during the short high-latitude summer, they aggressively feed on both aquatic and terrestrial (accidental intruder) macroinvertebrates. Of particular interest to our study is the "residence time" within which fish might be expected to inhabit a given reach of the river during the feeding period, to determine how much the geochemistry of a given section of the river might influence fish chemistry. Data suggest that the trace-element chemistry of resident fish is influenced more by diet than by the water column (Hershey and others, 1997). During the long high-latitude winter, grayling commonly migrate to areas of deep water, springs, or pipelike channels in aufeis where the water does not freeze completely. West and others (1992) reported that the migration distance between summer feeding areas and ice-free winter residence sites can exceed 100 $\mathrm{km}$ but commonly ranges from 25 to $75 \mathrm{~km}$. Although no studies have been conducted on the specific migratory habits of grayling in the Fortymile River (fig. 1), most grayling are speculated to migrate downstream to large pools, or even as far as the Yukon River, as much as $100 \mathrm{~km}$ from the farthest upstream fish-sampling site in this study. Kostohrys and others (1999) reported base flow for the main stem of the Fortymile River during January, February, and March (1990-95) to be generally $<1 \mathrm{~m}^{3} / \mathrm{s}$. In contrast, maximum flow during spring breakup in May can exceed $340 \mathrm{~m}^{3} / \mathrm{s}$. On April 2, 1998, we measured the flow on the North Fork of the Fortymile River $100 \mathrm{~m}$ above its confluence with the South Fork to be 0.59 to $0.76 \mathrm{~m}^{3} / \mathrm{s}$, indicating that fish along the main stem of the river probably migrate some distance because free-flowing water would not normally be available for oxygenation of overwintering, deep-water sites.

Buzby and Deegan (2000) reported that grayling studied along a stretch of the Kuparuk River north of the Brooks Range displayed remarkable interyear fidelity to summer feeding sites - that is, more than half the fish were recaptured within $300 \mathrm{~m}$ of the site where they had been captured in previous years. They attributed this behavior to adaptation that selects for fish returning to productive drift-feeding sites in the river where little time is available during the short summer feeding period for the exploration of alternative feeding locations. Furthermore, Reynolds (1997) reported that grayling appear to be remarkably faithful to overwintering sites as well, and so, for our study, we consider it reasonable to assume that the fish we sampled have been feeding along that particular section of the river in past years. Therefore, geochemical signatures for the fish-sampling sites, as defined by the geochemistry of surface water, stream sediment, and local lithologic units, probably influence the chemistry of fish tissue.

The purposes of this study were to (1) establish biogeochemical-baseline data for the muscle and liver tissues of Arctic grayling along the lower reaches of the Fortymile River within the Fortymile Mining District, (2) establish biogeochemical-baseline data for fish-forage organisms as measured on whole-gut content, and (3) analyze the biogeochemical elemental and stable-isotopic patterns related to 


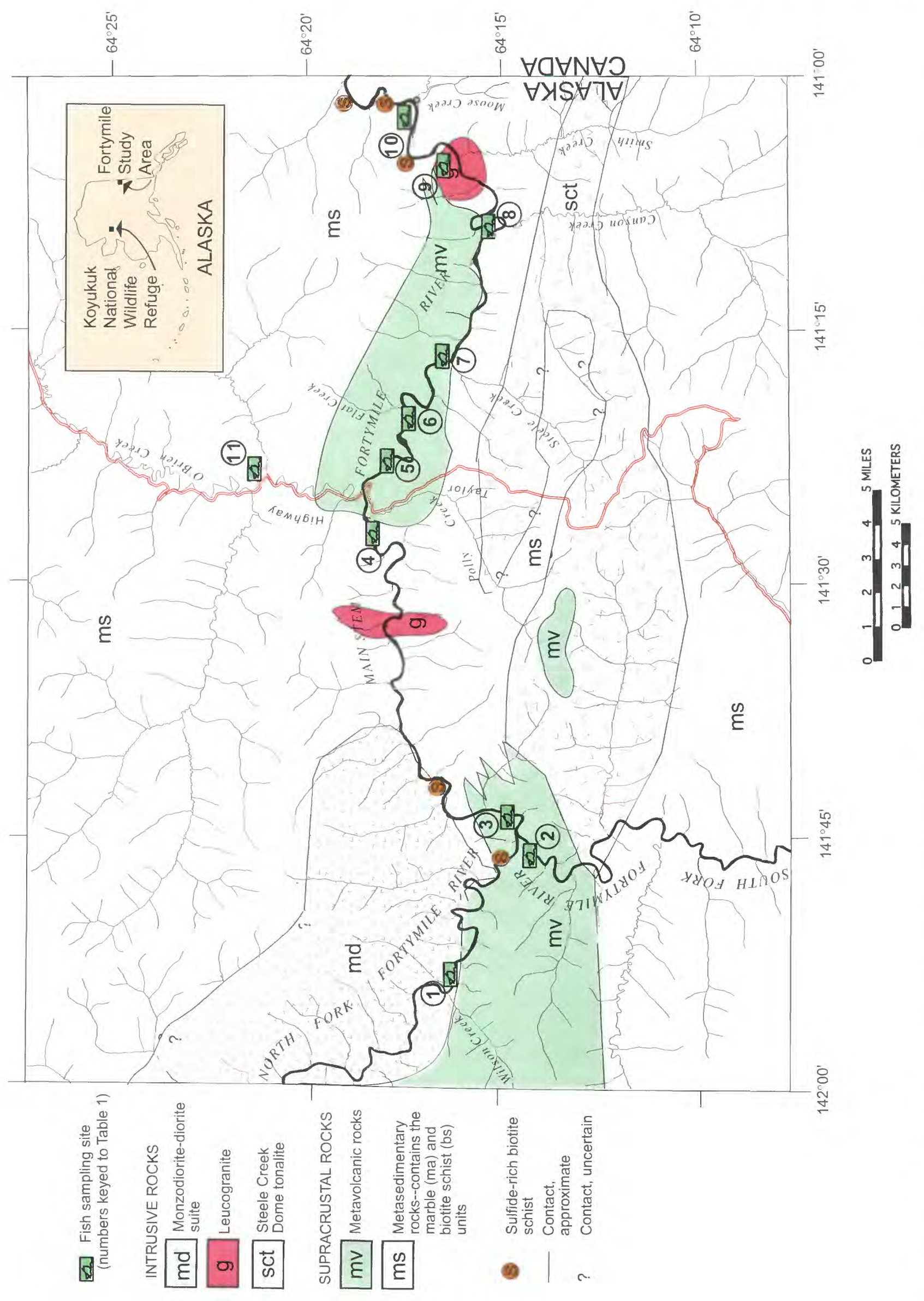


regional geochemistry - that is, in relation to surface water, stream sediment, and local lithologic units. This study presents muscle-tissue and stomach-content data for 38 major and trace elements in 34 fish collected from 11 sampling sites in the watershed. In addition, we present $\mathrm{N}$-, C-, and S-isotopic data for muscle samples. These data are the first to be reported for Arctic grayling in this region of Alaska.

\section{Methods}

\section{Field}

Fish were collected by using rod and lure on September 10-12, 2000. Three fish, each of approximately the same weight and length, were collected at each of 10 sampling sites along an 80-km stretch of the North Fork, South Fork, and main stem of the Fortymile River (fig. 1; table 1). Site localities are identified by geographic coordinates and by the name of the tributary nearest to where the fish were collected (table 1). In addition to these collections, four fish were collected from O'Brien Creek, about $13 \mathrm{~km}$ north of its confluence with the main stem. Thus, a total of 34 fish make up the sample population for this study (table 2).

Lithologic units that dominate the study area are mapped in figure 1 and listed in table 1 . Seven fish-sampling sites fell within the metavolcanic rocks (unit mv), 3 within the metasedimentary rocks (unit ms), and 1 within the intrusive leucogranite (unit g). A detailed discussion of the regional geology, soils, and biogeochemistry of the lower Fortymile River is presented in companion studies (see chap. 1; Day and others, 2000; Gough and others, 2001).

Fish were dissected in the field, and muscle (fillet), liver, and stomach contents were harvested. A stainless-steel blade was used in the dissection; the blade was wiped clean with disposable tissue and rinsed, using distilled water, before each organ dissection. Because of the small volume of material, the livers from the fish collected at each site were composited, as were the stomach contents. Samples were individually placed in plastic bags, double-sealed, and frozen. A total of 11 samples each of liver tissue and stomach contents and 34 samples of muscle tissue were thus obtained. Samples were kept frozen and shipped to the U.S. Geological Survey laboratories in Denver, Colo. Owing to insufficient material, stomach contents were not identified in the 2000 material that was used for chemical analysis. A resampling of three of the fish-sampling sites was conducted in 2001 within the same timeframe as for the 2000 sampling, and the stomach contents from three fish were examined (but not chemically analyzed). We assume that the stomach contents sampled 12 months later in 2001 are similar in invertebrate composition and proportion.

Table 1. Locations and description of fish-sampling sites in the Fortymile River study area, eastern Alaska.

[See figure 1 for locations and local geology. Units: $\mathrm{g}$, leucogranite; ms, metasedimentary rocks; mv, metavolcanic rocks]

\begin{tabular}{|c|c|c|c|c|}
\hline Site & Description & Lat ${ }^{\circ} \mathrm{N}$. & Long ${ }^{\circ} \mathrm{W}$. & Unit \\
\hline 1 & $\begin{array}{l}\text { North Fork, } 0.1 \mathrm{~km} \text { upstream of } \\
\text { confluence with Wilson Creek, near } \\
\text { right bank. }\end{array}$ & 64.2722 & 141.9045 & $\mathrm{mv}$ \\
\hline 2 & $\begin{array}{l}\text { South Fork, } 0.75 \mathrm{~km} \text { upstream of } \\
\text { confluence with the North Fork, } \\
\text { near left bank. }\end{array}$ & 64.2381 & 141.7567 & $\mathrm{mv}$ \\
\hline 3 & $\begin{array}{l}\text { Main stem, } 0.75 \mathrm{~km} \text { downstream of } \\
\text { confluence with the South and North } \\
\text { Forks, near left bank. }\end{array}$ & 64.2422 & 141.7406 & $\mathrm{mv}$ \\
\hline 4 & $\begin{array}{l}\text { Main stem, } 0.5 \mathrm{~km} \text { downstream of } \\
\text { confluence with Polly Creek, near } \\
\text { right bank. }\end{array}$ & 64.3086 & 141.4292 & $\mathrm{mv}$ \\
\hline 5 & $\begin{array}{l}\text { Main stem, } 1.5 \mathrm{~km} \text { below the Taylor } \\
\text { Highway Bridge, near left bank (no- } \\
\text { name creek). }\end{array}$ & 64.2937 & 141.3757 & $\mathrm{mv}$ \\
\hline 6 & $\begin{array}{l}\text { Main stem, } 0.5 \mathrm{~km} \text { below confluence } \\
\text { with Flat Creek, near left bank. }\end{array}$ & 64.2929 & 141.3191 & $\mathrm{mv}$ \\
\hline 7 & $\begin{array}{l}\text { Main stem, } 0.1 \mathrm{~km} \text { below confluence } \\
\text { with Steele Creek, near right bank. }\end{array}$ & 64.2767 & 141.2857 & $\mathrm{mv}$ \\
\hline 8 & $\begin{array}{l}\text { Main stem, } 1.5 \mathrm{~km} \text { below confluence } \\
\text { with Canyon Creek, near right bank. }\end{array}$ & 64.2633 & 141.1443 & $\mathrm{~ms}$ \\
\hline 9 & $\begin{array}{l}\text { Main stem, } 0.1 \mathrm{~km} \text { below confluence } \\
\text { with Smith Creek, near right bank. }\end{array}$ & 64.2683 & 141.0804 & $\mathrm{~g}$ \\
\hline 10 & $\begin{array}{l}\text { Main stem, } 0.1 \mathrm{~km} \text { below confluence } \\
\text { with Moose Creek, near right bank. }\end{array}$ & 64.2999 & 141.0262 & $\mathrm{~ms}$ \\
\hline 11 & $\begin{array}{l}\text { O'Brien Creek, at confluence with } \\
\text { Alder Creek }\end{array}$ & 64.4053 & 141.4050 & $\mathrm{~ms}$ \\
\hline
\end{tabular}


Table 2. Summary statistics for weight and total length of Arctic grayling collected from the Fortymile River, eastern Alaska.

[See figure 1 for locations. Distances are measured from confluence of the North and South Forks that forms the main stem of the Fortymile River. Negative values, upstream (on the North Fork); positive values, downstream (on main stem)]

\begin{tabular}{|c|c|c|c|c|}
\hline Sample & Sex & $\begin{array}{c}\text { Wet } \\
\text { weight } \\
(\mathrm{kg})\end{array}$ & $\begin{array}{l}\text { Length } \\
\text { (cm) }\end{array}$ & $\begin{array}{c}\text { Distance } \\
(\mathrm{km})\end{array}$ \\
\hline $\begin{array}{l}\text { Wilson Creek-1 } \\
\text { Wilson Creek-2 } \\
\text { Wilson Creek-3 } \\
\text { Arithmetic m } \\
\text { Standard dev }\end{array}$ & $\begin{array}{l}\mathrm{F} \\
\mathrm{M} \\
\mathrm{M}\end{array}$ & $\begin{array}{r}0.47 \\
.19 \\
.14 \\
.27 \\
.18\end{array}$ & $\begin{array}{r}330 \\
292 \\
260 \\
294 \\
35\end{array}$ & $\begin{array}{l}-15 \\
-15 \\
-15\end{array}$ \\
\hline $\begin{array}{l}\text { South Fork-1 } \\
\text { South Fork-2 } \\
\text { South Fork-3 } \\
\text { Arithmetic m } \\
\text { Standard dev }\end{array}$ & $\begin{array}{l}M \\
M \\
F\end{array}$ & $\begin{array}{l}.42 \\
.24 \\
.39 \\
.35 \\
.10\end{array}$ & $\begin{array}{r}356 \\
305 \\
356 \\
339 \\
29\end{array}$ & $\begin{array}{l}-.3 \\
-.3 \\
-.3\end{array}$ \\
\hline $\begin{array}{l}\text { North Fork-1 } \\
\text { North Fork-2 } \\
\text { North Fork-3 } \\
\text { Arithmetic m } \\
\text { Standard dev }\end{array}$ & \begin{tabular}{l}
$\mathrm{M}$ \\
$\mathrm{M}$ \\
$\mathrm{M}$ \\
\hdashline
\end{tabular} & $\begin{array}{l}.39 \\
.42 \\
.46 \\
.42 \\
.04\end{array}$ & $\begin{array}{r}356 \\
357 \\
362 \\
358 \\
3.2\end{array}$ & $\begin{array}{l}.3 \\
.3 \\
.3\end{array}$ \\
\hline $\begin{array}{l}\text { Polly Creek-1 } \\
\text { Polly Creek-2 } \\
\text { Polly Creek-3 } \\
\text { Arithmetic m } \\
\text { Standard dev }\end{array}$ & $\begin{array}{l}\mathrm{M} \\
\mathrm{F} \\
\mathrm{M}\end{array}$ & $\begin{array}{l}.34 \\
.44 \\
.38 \\
.39 \\
.05\end{array}$ & $\begin{array}{r}356 \\
357 \\
343 \\
351 \\
7.8\end{array}$ & $\begin{array}{l}27 \\
27 \\
27\end{array}$ \\
\hline $\begin{array}{l}\text { No-name creek-1 } \\
\text { No-name creek-2 } \\
\text { No-name creek-3 } \\
\text { Arithmetic m } \\
\text { Standard dev }\end{array}$ & $\begin{array}{l}M \\
M \\
M\end{array}$ & $\begin{array}{l}.16 \\
.34 \\
.19 \\
.23 \\
.10\end{array}$ & $\begin{array}{r}273 \\
342 \\
279 \\
299 \\
38\end{array}$ & $\begin{array}{l}31 \\
31 \\
31\end{array}$ \\
\hline $\begin{array}{l}\text { Flat Creek-1 } \\
\text { Flat Creek-2 } \\
\text { Flat Creek-3 } \\
\text { Arithmetic m } \\
\text { Standard dev }\end{array}$ & $\begin{array}{l}\mathrm{F} \\
\mathrm{F} \\
\mathrm{M}\end{array}$ & $\begin{array}{l}.32 \\
.14 \\
.18 \\
.21 \\
.09\end{array}$ & $\begin{array}{r}318 \\
241 \\
267 \\
275 \\
39\end{array}$ & $\begin{array}{l}35 \\
35 \\
35\end{array}$ \\
\hline $\begin{array}{l}\text { Steele Creek-1 } \\
\text { Steele Creek-2 } \\
\text { Steele Creek-3 } \\
\text { Arithmetic m } \\
\text { Standard dev }\end{array}$ & \begin{tabular}{l}
$\mathrm{M}$ \\
$\mathrm{M}$ \\
$\mathrm{M}$ \\
\hdashline
\end{tabular} & $\begin{array}{l}.52 \\
.18 \\
.22 \\
.31 \\
.19\end{array}$ & $\begin{array}{r}394 \\
267 \\
304 \\
322 \\
65\end{array}$ & $\begin{array}{l}41 \\
41 \\
41\end{array}$ \\
\hline $\begin{array}{r}\text { Canyon Creek-1 } \\
\text { Canyon Creek-2 } \\
\text { Canyon Creek-3 } \\
\text { Arithmetic m } \\
\text { Standard dev }\end{array}$ & \begin{tabular}{l}
$\mathrm{F}$ \\
$\mathrm{M}$ \\
$\mathrm{M}$ \\
\hdashline
\end{tabular} & $\begin{array}{l}.31 \\
.20 \\
.23 \\
.25 \\
.06\end{array}$ & $\begin{array}{r}318 \\
279 \\
292 \\
296 \\
20\end{array}$ & $\begin{array}{l}50 \\
50 \\
50\end{array}$ \\
\hline $\begin{array}{l}\text { Smith Creek-1 } \\
\text { Smith Creek-2 } \\
\text { Smith Creek-3 } \\
\text { Arithmetic m } \\
\text { Standard dev }\end{array}$ & \begin{tabular}{l}
$M$ \\
$M$ \\
$\mathrm{~F}$ \\
\hdashline
\end{tabular} & $\begin{array}{l}.38 \\
.42 \\
.29 \\
.36 \\
.07\end{array}$ & $\begin{array}{r}356 \\
343 \\
318 \\
339 \\
19\end{array}$ & $\begin{array}{l}58 \\
58 \\
58\end{array}$ \\
\hline $\begin{array}{l}\text { Moose Creek-1 } \\
\text { Moose Creek-2 } \\
\text { Moose Creek-3 } \\
\text { Arithmetic m } \\
\text { Standard dev }\end{array}$ & \begin{tabular}{l}
$\mathrm{M}$ \\
$\mathrm{F}$ \\
$\mathrm{F}$ \\
\hdashline
\end{tabular} & $\begin{array}{l}.36 \\
.38 \\
.32 \\
.35 \\
.03\end{array}$ & $\begin{array}{r}356 \\
349 \\
311 \\
339 \\
24\end{array}$ & $\begin{array}{l}64 \\
64 \\
64\end{array}$ \\
\hline $\begin{array}{r}\text { O'Brien Creek-1 } \\
\text { O'Brien Creek-2 } \\
\text { O'Brien Creek-3 } \\
\text { O'Brien Creek-4 } \\
\text { Arithmetic m } \\
\text { Standard dev }\end{array}$ & $\begin{array}{l}\mathrm{M} \\
\mathrm{M} \\
\mathrm{F} \\
\mathrm{F}\end{array}$ & $\begin{array}{l}\quad .34 \\
.48 \\
.34 \\
.38 \\
.35 \\
.07\end{array}$ & $\begin{array}{r}318 \\
368 \\
330 \\
330 \\
337 \\
22\end{array}$ & $\left.\begin{array}{l}1 \\
1 \\
1 \\
1 \\
1 \\
1\end{array}\right)$ \\
\hline
\end{tabular}

'Upstream on O'Brien Creek, $13 \mathrm{~km}$ from its confluence with the main stem of the Fortymile River.

\section{Laboratory}

In the laboratory, fish tissue was thawed, washed thoroughly in deionized water, and digested in ultrapure $\mathrm{HNO}_{3}$ and 30 volume percent $\mathrm{H}_{2} \mathrm{O}_{2}$ (CEM Corp., 1994). All elemental analyses (except $\mathrm{Hg}$ ) were performed by using inductively coupled plasma mass spectrometry on the acid-digested material; $\mathrm{Hg}$ analyses were performed on a separate aliquot of the digested material (which was redigested with $\mathrm{HNO}_{3} / \mathrm{Na}_{2} \mathrm{Cr}_{2} \mathrm{O}_{7}$ ), using cold-vapor atomic-absorption spectroscopy (Kennedy and Crock, 1987). For quality-control purposes, standard reference materials, analytical duplicates, and matrix spike samples were analyzed by the same analytical methods (Taggart, 2002).

Stable-isotopic analyses (N, C, S) were made by using a Thermofinnigan Delta Plus mass spectrometer, coupled with a Carlo Erba NC2500 Elemental Analyzer. Sample sizes for $\mathrm{N}$ - and $\mathrm{C}$-isotopic analyses were approximately $0.5 \mathrm{mg}$, and for $\mathrm{S}$-isotopic analyses approximately $5.0 \mathrm{mg} . \mathrm{N}-, \mathrm{C}-$, and S-isotopic compositions were measured on $\mathrm{N}_{2}, \mathrm{CO}_{2}$, and $\mathrm{SO}_{2}$ gas, respectively. Data are reported in $\delta$-notation relative to the references of air for N, Vienna Pee Dee belemnite (VPDB) for C, and Vienna Canyon Diablo troilite (VCDT) for S. The $\delta$-notation for the ${ }^{15} \mathrm{~N} /{ }^{14} \mathrm{~N},{ }^{13} \mathrm{C} /{ }^{12} \mathrm{C}$, and ${ }^{34} \mathrm{~S} /{ }^{22} \mathrm{~S}$ ratios of a substance is defined as

$$
\delta^{15} \mathrm{~N}, \delta^{13} \mathrm{C} \text {, or } \delta^{34} \mathrm{~S}=\left(\frac{R_{\text {sample }}-R_{\text {reference }}}{R_{\text {reference }}}\right) \times 1,000,
$$

where the $\delta$ value is in parts per thousand, or permil, and $R$ is the ratio of interest $\left({ }^{15} \mathrm{~N} /{ }^{14} \mathrm{~N},{ }^{13} \mathrm{C} /{ }^{12} \mathrm{C}\right.$, or $\left.{ }^{34} \mathrm{~S} /{ }^{32} \mathrm{~S}\right)$. The $\mathrm{N}$ - and $\mathrm{C}$-isotopic compositions were calibrated relative to a scale based on two samples of glutamic acid selected for use as laboratory reference materials: one with $\delta^{15} \mathrm{~N}=-4.6$ permil and $\delta^{13} \mathrm{C}=32.5$ permil, and the other with $\delta^{15} \mathrm{~N}=49.3$ permil and $\delta^{13} \mathrm{C}=-26.2$ permil, whose compositions, in turn, are based on a scale defined by the international reference materials NBS-19 $\left(\delta^{13} \mathrm{C}=1.95\right.$ permil $)$, LSVEC $\left(\delta^{13} \mathrm{C}=-46.48\right.$ permil $)$, IAEA-N $1\left(\delta^{15} \mathrm{~N}=0.4\right.$ permil), and USGS-32 $\left(\delta^{15} \mathrm{~N}=180\right.$ permil). S-isotopic compositions were measured on $\mathrm{SO}_{2}$ gas on a scale defined by the reference materials NBS-123 $\left(\delta^{34} \mathrm{~S}=17.09\right.$ permil) and Maine Light $\left(\delta^{34} S=-30.7\right.$ permil). The analytical uncertainties $(1 \sigma)$ are \pm 0.3 permil for $N$ isotopes, \pm 0.2 permil for $\mathrm{C}$ isotopes, and \pm 0.3 permil for $\mathrm{S}$ isotopes.

Fish stomachs, whose contents were used for macroinvertebrate identification, were removed from the fish, frozen, and sent to the Alaska Department of Fish and Game laboratories. There, the material was thawed, and the contents were removed from both the anterior and posterior parts of the stomach and preserved separately in 70-volume-percent ethanol.

\section{Data Analysis}

The Arctic grayling in our study ranged in weight from 0.21 to $0.42 \mathrm{~kg}$ (wet weight) and in total length from 275 to $358 \mathrm{~mm}$ (estimated fork length, $250-330 \mathrm{~mm}$, based on the total-length versus fork-length regression of Grabacki, 1981) 
(table 2). We did not determine the age of any of the fish collected in this study. Studies that correlate Arctic grayling age and length appear to be specific to a given drainage up to an age of about 5-7 years (Merritt, 1989). After age 5-7 (depending on the population), the correlation between age and length is less certain. Hughes (1999) reported Arctic grayling from the Goodpaster River, interior Alaska, with a size range to that of our fish (229-298 mm long), to be 4-6 years old, whereas Merritt reported Arctic grayling from the Seward Peninsula in this same size range to be 3-7 years old.

All the fish in our study were sexually mature, and 32 percent were female. For the purposes of this study, both sexes were combined in the calculations of summary statistics (table 2). The major- and trace-element analyses of fish muscle and liver tissue and stomach contents (wet-weight basis) are summarized in tables 3 through 5 . Multiplying these data by 4 results in a close estimate of the concentrations converted to a dry-weight basis (Chen and others, 2001). Typical frequency diagrams of the elemental concentrations represented by $\mathrm{Mg}$ and $\mathrm{Hg}$ in muscle tissue are plotted in figure 2. Because logtransformed data generally displayed more normal distributions (as measured by skewness and kurtosis), we subsequently used the transformed data for all statistical analyses.

Most statistical analyses depend on the use of uncensored data (values above the lower limit of detection [LLD]). In samples where the censored data (values below the LLD) for a particular element in a particular tissue did not exceed 33 percent, we followed the convention of Miesch (1976) and substituted a value of $0.7 \times$ LLD. For example, 12 of the 34 measured $\mathrm{Cu}$ contents in muscle tissue were censored (table 3 ). Whenever $\mathrm{Cu}$ is included in a statistical test, a value of $0.35 \mathrm{ppm}(0.7 \times 0.5 \mathrm{ppm})$ is substituted for the censored data

Fish sampling for this study focused on older, sexually mature individuals. Fish weights, therefore, varied only by about a factor or 2 or less (table 2). Nevertheless, the variation in fish chemistry that is associated with differences in fish size (weight) is a concern because the main emphasis in this study is on the relation of fish chemistry to regional lithology. Using fish weight as a proxy for age, we have assigned but one "age" class in the interpretation of the chemical data and normalized the elemental concentrations to fish weight. This transformation decreased the data variance associated with differences in fish weight (age).

Macroinvertebrates were counted in samples of material from both the anterior and posterior parts of the stomach; contents of the intestine were generally too digested to identify. The relative numbers of invertebrates in each fish were counted. We also determined the total number of identified taxa (generally at the genus level), the relative proportion of aquatic to terrestrial organisms, and the proportions of EPT (Ephemeroptera-Plecoptera-Trichoptera combined) taxa, Chironomidae, and dominant taxa (an indication of selective feeding).
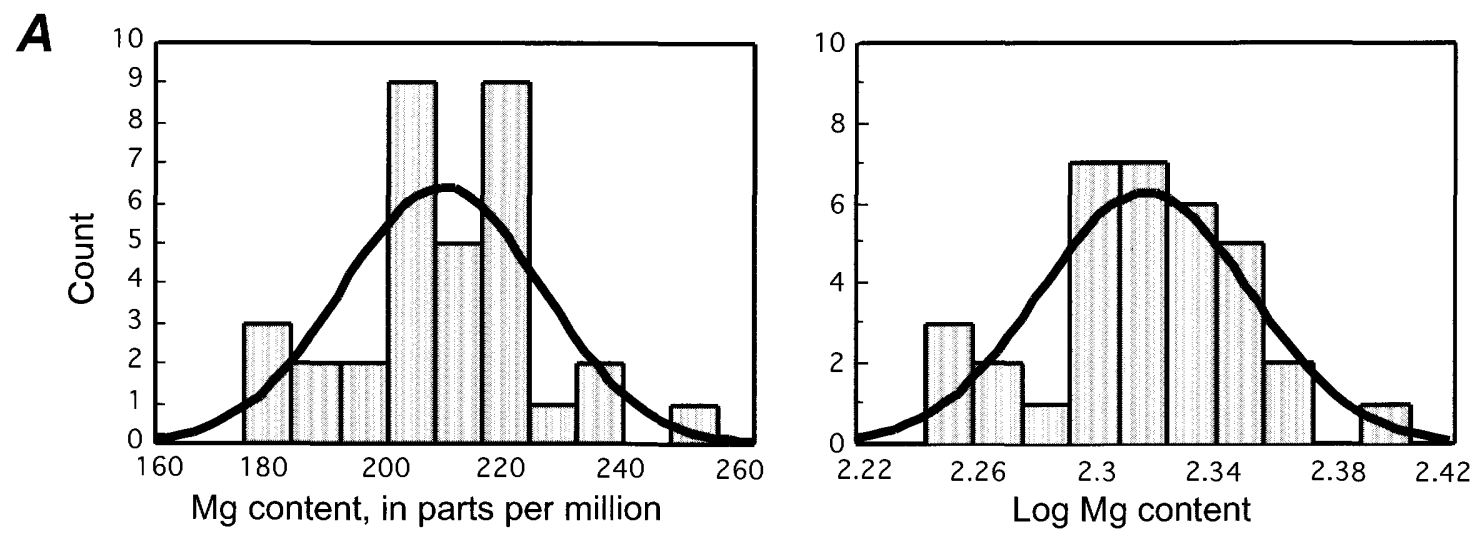

B

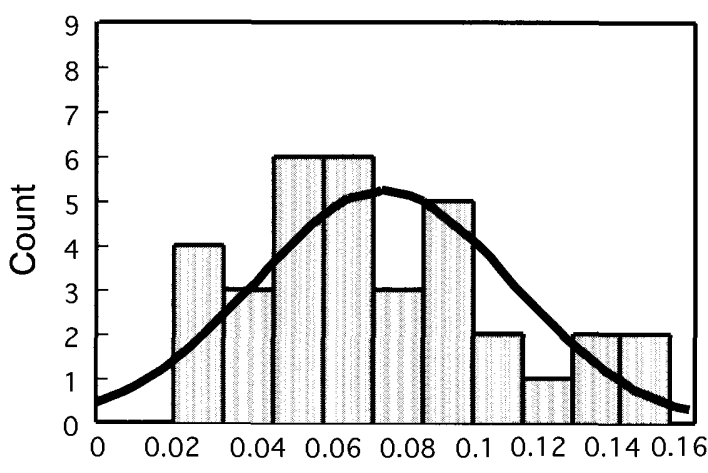

$\mathrm{Hg}$ content, in parts per million

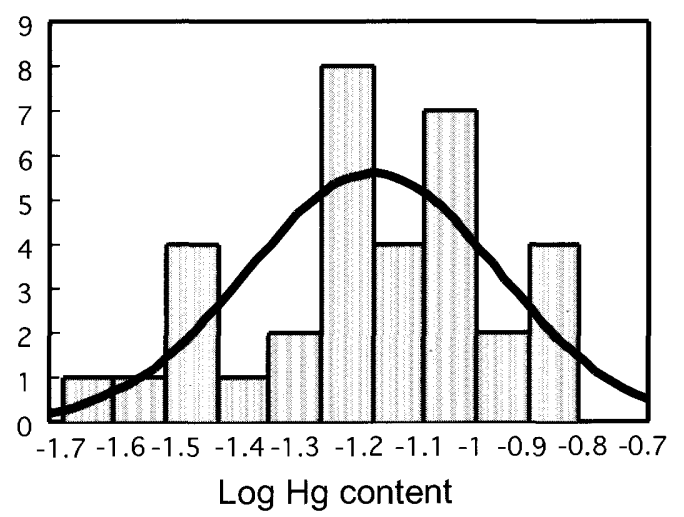

Figure 2. Bar charts of typical arithmetic (left plot) and logarithmic (right plot) frequency distributions $(n=34)$ of elemental concentrations of $\mathrm{Mg}(A)$ and $\mathrm{Hg}(B)$ in muscle tissue of Arctic grayling collected from the Fortymile River, eastern Alaska (fig. 1). 
Table 3. Summary statistics for elemental concentrations in muscle tissue of Arctic grayling collected from the Fortymile River, eastern Alaska, in comparison with grayling from Koyukuk National Wildlife Refuge.

[See figure 1 for locations. All Fortymile concentration data reported in parts per million wet weight, all Koyukuk concentration data reported in parts per million dry weight (Phyllis Weber-Scannell, unpub. data, 1999). LLD, lower limit of detection; analytical-detection ratio, ratio of number of uncensored (above LLD) analytical values to total number of analyses. Dashes, not calculated because of the presence of censored (below LLD) analytical values; n.d., not determined or available. Data from Crock and others (2003)]

\begin{tabular}{|c|c|c|c|c|c|c|}
\hline \multirow[b]{2}{*}{ Element } & \multirow{2}{*}{$\begin{array}{l}\text { LLD } \\
(\mathrm{ppm})\end{array}$} & \multirow{2}{*}{$\begin{array}{l}\text { Analytical- } \\
\text { detection } \\
\text { ratio }\end{array}$} & \multirow{2}{*}{$\begin{array}{c}\text { Geometric } \\
\text { mean } \\
(\mathrm{ppm})\end{array}$} & \multirow{2}{*}{$\begin{array}{l}\text { Geometric } \\
\text { deviation }\end{array}$} & \multicolumn{2}{|c|}{ Observed range (ppm) } \\
\hline & & & & & $\begin{array}{c}\text { Fortymile } \\
(n=34)\end{array}$ & $\underset{(n=8)}{\text { Koyukuk }}$ \\
\hline Ag -............ & 0.02 & $0: 34$ & -- & -- & $<0.02-0.02$ & $<0.4-<0.4$ \\
\hline Al -... & 8 & $0: 34$ & -- & -- & $<8<8$ & $<1.9-2.9$ \\
\hline As ---.---.--. & .1 & $0: 34$ & -- & -- & $<1<0.1$ & $<.5<0.5$ \\
\hline $\mathrm{Ba}$ & .5 & $0: 34$ & -- & -- & $<.5<0.5$ & $<.1-0.65$ \\
\hline $\mathrm{Be}$ & .001 & $4: 34$ & -- & -- & $<.001-0.001$ & $<.1<0.1$ \\
\hline Bi-..-.....- & .005 & $0: 34$ & -- & -- & $<.005-0.005$ & n.d. \\
\hline $\mathrm{Ca}$ & 20 & $33: 34$ & -- & -- & $<20-2,280$ & n.d. \\
\hline Cd -........... & .003 & $5: 34$ & -- & -- & $<.003-1.2$ & $<.5-<0.5$ \\
\hline $\mathrm{Ce}$ & .5 & $0: 34$ & -- & -- & $<.5-0.5$ & n.d. \\
\hline Co -.....-..... & .1 & $0: 34$ & - - & -- & $<.1<0.1$ & n.d. \\
\hline Cr -...-......... & .2 & $34: 34$ & .4 & 1.09 & $3-0.5$ & $<3-0.3$ \\
\hline Cs -............... & .003 & $34: 34$ & .019 & 2.05 & $.004-0.016$ & n.d. \\
\hline $\mathrm{Cu}$ & .5 & $22: 34$ & -- & -0 & $<.5-1.3$ & $1.6-2.7$ \\
\hline $\mathrm{Fe}$ & 50 & $0: 34$ & -- & -- & $<50<50$ & $21-40$ \\
\hline $\mathrm{Ga}$ & .006 & $34: 34$ & .02 & 1.32 & $.01-0.03$ & n.d. \\
\hline Hg (total) ---- & .004 & $34: 34$ & .069 & 1.62 & $.021-0.15$ & $.22-0.66$ \\
\hline K - & 20 & $34: 34$ & 3,750 & 1.07 & $3,240-4,110$ & n.d. \\
\hline La --.--..-.... & .3 & $0: 34$ & , & -- & $<.3<0.3$ & n.d. \\
\hline $\mathrm{Li}$ & 2 & 0.34 & -- & -- & $<2<0.2$ & n.d. \\
\hline Mg -.--.-.-.. & 3 & $34: 34$ & 210 & 1.08 & $175-254$ & $1,000-1,200$ \\
\hline Mn -- & .2 & $12: 22$ & - & -- & $<.2-2.8$ & $1.1-1.8$ \\
\hline Mo --.---.-.- & .1 & $0: 34$ & -- & -- & $<.1<0.1$ & $<30-0.33$ \\
\hline $\mathrm{Na}$ & 6 & $34: 34$ & 220 & 1.15 & $182-344$ & n.d. \\
\hline Nb--.-........ & 2 & $0: 34$ & 220 & -- & $<2<2$ & n.d. \\
\hline $\mathrm{Ni}$ & 1 & $0: 34$ & -- & -- & $<1<1$ & $<1.0-1.0$ \\
\hline $\mathrm{Pb}$ & .2 & $0: 34$ & -- & -- & $<.2<0.2$ & $<3.0<3.0$ \\
\hline P--.---.--. & $8^{.2}$ & $34: 34$ & -- & -- & $<8<-8$ & n.d. \\
\hline $\mathrm{Rb}$ & .01 & $34: 34$ & 4.1 & 1.44 & $2.2-9.9$ & n.d. \\
\hline Sb --.--.-- & .02 & $0: 34$ & - - & -- & $<.02<0.02$ & $<3.0<3.0$ \\
\hline Sc -........... & .3 & $0: 34$ & -- & -- & $<3<0.3$ & n.d. \\
\hline Se -.........-. & .2 & $33: 34$ & -- & -- & $<2-1.5$ & $1.5-2.3$ \\
\hline Sr & .05 & $15: 19$ & -- & -- & $<.05-5.9$ & $<1.5-4.7$ \\
\hline Th -..-.-.-.-.- & .03 & $0: 34$ & -- & -- & $<.03-<0.03$ & n.d. \\
\hline Ti -....-...-.-. & $40^{.00}$ & $0: 34$ & -- & -- & $<40<<0$ & n.d. \\
\hline Tl-_-_-_-_-_. & .003 & $31: 34$ & -- & -- & $<.003-0.009$ & $<11-11$ \\
\hline U -.----------. & .02 & $0: 34$ & -- & -- & $<.02-<0.02$ & n.d. \\
\hline V -..---.----.- & .4 & $0: 34$ & -- & -- & $<4<0.4$ & $<3-<0.3$ \\
\hline Zn --.---..--..- & 5 & $2: 34$ & -- & -- & $<5-6$ & $11-16$ \\
\hline
\end{tabular}

\section{Results}

\section{Fish Inorganic Chemistry}

\section{Biogeochemical-Baseline Estimations}

The geometric mean (GM value) and geometric deviation (GD value) for 38 elemental concentrations in muscle tissue, liver tissue, and stomach contents are listed in tables 3,4 , and 5, respectively, along with the LLD, the analyticaldetection ratio (that is, the ratio of the number of uncensored data to the total number of analyses), and the observed range for each element. We did not calculate the GM and GD values for elements with censored data; however, we do report the observed ranges for these elements. The GM and GD values and observed ranges can be used together to estimate biogeochemical baselines for grayling in the lower reaches of the Fortymile River. A more precise determination of biogeochemical baseline should await additional sampling of fish from second- and third-order streams within the watershed, as well as at other times within the life history of grayling.

The wet-weight base element ranges for the muscle and liver tissues of grayling collected from the Fortymile River area (fig. 1) are compared, in tables 3 and 4, with similar material (dry-weight basis) collected in Koyukuk National Wildlife Refuge, western Alaska (Mueller and others, 1996). 
Table 4. Summary statistics for elemental concentrations in liver tissue of Arctic grayling collected from the Fortymile River, eastern Alaska, in comparison with grayling from Koyukuk National Wildlife Refuge.

[See figure 1 for locations. All Fortymile concentration data reported in parts per million wet weight, all Koyukuk concentration data reported in parts per million dry weight (Phyllis Weber-Scannell, unpub. data, 1999). LLD, lower limit of detection; analytical-detection ratio, ratio of number of uncensored (above LLD) analytical values to total number of analyses. Dashes, not calculated because of the presence of censored (below LLD) analytical values; n.d., not determined or available. Data from Crock and others (2003)]

\begin{tabular}{|c|c|c|c|c|c|c|}
\hline \multirow[b]{2}{*}{ Element } & \multirow{2}{*}{$\begin{array}{l}\text { LLD } \\
(\mathrm{ppm})\end{array}$} & \multirow{2}{*}{$\begin{array}{l}\text { Analytical- } \\
\text { detection } \\
\text { ratio }\end{array}$} & \multirow{2}{*}{$\begin{array}{c}\text { Geometric } \\
\text { mean } \\
(\mathrm{ppm})\end{array}$} & \multirow{2}{*}{$\begin{array}{c}\text { Geometric } \\
\text { deviation }\end{array}$} & \multicolumn{2}{|c|}{ Observed range (ppm) } \\
\hline & & & & & $\begin{array}{c}\text { Fortymile } \\
(n=11)\end{array}$ & $\underset{(n=8)}{\text { Koyukuk }}$ \\
\hline $\mathrm{Ag}$ & 0.02 & $0: 11$ & -- & -- & $<0.02-<0.02$ & $<0.4<0.4$ \\
\hline $\mathrm{Al}$ & 8 & $0: 11$ & -- & -- & $<8-8$ & $21-37$ \\
\hline As - & .1 & $9: 11$ & -- & -- & $<.1-0.2$ & n.d. \\
\hline $\mathrm{Ba}$ & .5 & $0: 11$ & -- & -- & $<.5<<0.5$ & $<.1-0.29$ \\
\hline $\mathrm{Be}$ & .001 & $5: 11$ & -- & -- & $<.001-0.001$ & $<.1<0.1$ \\
\hline Bi-_.......... & .005 & $6: 11$ & -- & -- & $<.005-0.01$ & n.d. \\
\hline Ca -......-.-. & & $5: 11$ & -- & -- & $<20-55$ & n.d. \\
\hline Cd -............ & .003 & $11: 11$ & .27 & 1.85 & $.09-0.63$ & $<.1-1.1$ \\
\hline $\mathrm{Ce}$ & .5 & $0: 11$ & - & -- & $<0.5-<0.5$ & n.d. \\
\hline Co -..-..-...-.- & .1 & $11: 11$ & .19 & 1.36 & $.13-0.35$ & n.d. \\
\hline Cr & .2 & 11:11 & .4 & 1.20 & $.3-0.6$ & $<.7-0.85$ \\
\hline Cs & .003 & $11: 11$ & .015 & 1.83 & $.006-0.030$ & n.d. \\
\hline $\mathrm{Cu}$ & .5 & $11: 11$ & 1.7 & 1.32 & $1.0-2.6$ & $7.8-27$ \\
\hline $\mathrm{Fe}$ & 50 & $4: 11$ & -- & -- & $<50-70$ & $270-320$ \\
\hline $\mathrm{Ga}$ & .006 & $11: 11$ & .02 & .0 & $.02-0.02$ & n.d. \\
\hline $\mathrm{Hg}$ (total) & .004 & $11: 11$ & .062 & 1.53 & $.031-0.10$ & $.2-0.9$ \\
\hline $\mathrm{K}$ & 20 & $11: 11$ & 2,600 & 1.12 & $2,100-3,240$ & n.d. \\
\hline La -........- & .3 & $0: 11$ & -- & & $<.3-0.3$ & n.d. \\
\hline Li -............. & .2 & $0: 11$ & - - & -- & $<2-<0.2$ & n.d. \\
\hline Mg & .3 & 11:11 & 130 & 1.16 & $100-160$ & $630-700$ \\
\hline $\mathrm{Mn}$ & .2 & 11:11 & 1.5 & 1.2 & $1.1-1.9$ & $7.4-11$ \\
\hline Mo & .1 & $6: 11$ & -- & - & $<1-0.4$ & $<.4-0.84$ \\
\hline $\mathrm{Na}$ & 6 & $11: 11$ & 640 & 1.2 & $470-830$ & n.d. \\
\hline $\mathrm{Nb}$ & 2 & $0: 11$ & -- & -- & $<2<2$ & n.d. \\
\hline $\mathrm{Ni}$ & 1 & $0: 11$ & -- & -- & $<1<1$ & $<1.0-1.0$ \\
\hline Pb -.--..--.- & .2 & $0: 11$ & -- & -- & $<.2-<0.2$ & $<3.0-3.0$ \\
\hline P & 8 & 11:11 & 2,350 & 1.13 & $1,800-2,800$ & n.d. \\
\hline $\mathrm{Rb}$ & .01 & 11:11 & 5.6 & 1.24 & $4.4-9.5$ & n.d. \\
\hline Sb & .02 & $0: 11$ & -- & -- & $<.02<<<.02$ & $<3.0-3.0$ \\
\hline Sc -...-..-- & .3 & $0: 11$ & -- & -- & $<.3-0.3$ & n.d. \\
\hline Se -.........- & .2 & $0: 11$ & .67 & 1.73 & $.2-1.5$ & n.d. \\
\hline Sr-.........-. & .05 & $0: 11$ & -- & -- & $<.05-5.9$ & $<1.5-1.5$ \\
\hline Th -..---.----- & .03 & $0: 11$ & -- & -- & $<.03<0.03$ & n.d. \\
\hline 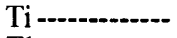 & 40 & $0: 11$ & -- & -- & $<40-<0$ & n.d. \\
\hline Tl -........... & .003 & $0: 11$ & -- & -- & $<.003-0.009$ & $<15-15$ \\
\hline U & .02 & $0: 11$ & -- & -- & $<.02-0.02$ & n.d. \\
\hline V & .4 & $0: 11$ & -- & -- & $<.4-<0.4$ & $.7-1.9$ \\
\hline Zn -.....- & 5 & $0: 11$ & -- & -- & $<5-6$ & $87-94$ \\
\hline
\end{tabular}

Like the Fortymile River area, Koyukuk National Wildlife Refuge is generally unmineralized (Mueller and others, 1996) but, unlike the Fortymile River area, is topographically flat and dominated by Quaternary glacial and glaciolacustrine deposits (Snyder-Conn and others, 1992). To compare our wet-weightbasis data with the Koyukuk dry-weight-basis data, a factor of 4 needs to be applied to the Koyukuk data (Chen and others, 2001). Nevertheless, with a few notable exceptions (for those elements with similar LLDs), the chemistries of fish muscle and liver tissue in these two areas appear to be nearly identical. Because few data on grayling chemistry are available, this comparison should serve as an initial benchmark for future assessments.

\section{Mercury}

The biogeochemical cycling and bioaccumulation of $\mathrm{Hg}$ in diverse ecosystems has received increasing attention since the 1990s (for example, Lindberg and others, 2000). Only a few studies, however, have been done on the $\mathrm{Hg}$ content in Arctic grayling (Gray and others, 1996, 2000; Duffy and others, 1999), reporting total $\mathrm{Hg}$ content and methylmercury (MeHg) concentrations in the muscle and liver tissues of fish collected in the Kuskokwim River watershed of southwestern Alaska - an area known for its $\mathrm{Hg}$ mineralization. $\mathrm{MeHg}$ accounted for $90-100$ percent of the total $\mathrm{Hg}$ content in muscle material in these studies. The $\mathrm{Hg}$ content in the muscle 
Table 5. Summary statistics for elemental concentrations in the stomach contents of Arctic grayling collected from the Fortymile River, eastern Alaska.

[See figure 1 for locations. All concentrations in parts per million wet weight. LLD, lower limit of detection; analytical-detection ratio, ratio of number of uncensored (above LLD) analytical values to total number of analyses. Dashes, not calculated because of the presence of censored (below LLD) analytical values. Data from Crock and others (2003)]

\begin{tabular}{|c|c|c|c|c|c|}
\hline Element & $\begin{array}{c}\text { LLD } \\
\text { (ppm) }\end{array}$ & $\begin{array}{l}\text { Analytical- } \\
\text { detection } \\
\text { ratio }\end{array}$ & $\begin{array}{c}\text { Geometric } \\
\text { mean } \\
(\mathrm{ppm})\end{array}$ & $\begin{array}{l}\text { Geometric } \\
\text { deviation }\end{array}$ & $\begin{array}{c}\text { Observed } \\
\text { range } \\
(\mathrm{ppm})\end{array}$ \\
\hline Ag - & 0.02 & $0: 11$ & -- & -- & $<0.02-<0.02$ \\
\hline Al -............... & 8 & $0: 11$ & -- & -- & $<8-<8$ \\
\hline As - & .1 & $10: 11$ & -- & -- & $<.1-0.6$ \\
\hline $\mathrm{Ba}-$ & .5 & $11: 11$ & 2.1 & 1.86 & $.84-5.2$ \\
\hline $\mathrm{Be}$ & .001 & $11: 11$ & .004 & 2.21 & $.003-0.01$ \\
\hline Bi-- & .005 & $5: 11$ & -- & -- & $<.005-0.01$ \\
\hline $\mathrm{Ca}$ & 20 & $11: 11$ & 140 & 1.92 & $59-510$ \\
\hline Cd -................. & .003 & $11: 11$ & .13 & 1.68 & $.06-0.29$ \\
\hline $\mathrm{Ce}$ & .5 & $3: 11$ & -- & -- & $<.5-1.0$ \\
\hline 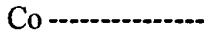 & .1 & $6: 11$ & -- & -- & $<.1-0.37$ \\
\hline $\mathrm{Cr}$ & .2 & $11: 11$ & .72 & 1.79 & $.4-3.1$ \\
\hline Cs -.................. & .003 & $11: 11$ & .02 & 1.84 & $.008-0.06$ \\
\hline $\mathrm{Cu}$ & .5 & $11: 11$ & 5.6 & 1.47 & $2.4-9.1$ \\
\hline Fe - & 50 & $11: 11$ & 170 & 2.41 & $50-710$ \\
\hline $\mathrm{Ga}-$ & .006 & $11: 11$ & .04 & 1.9 & $.02-0.1$ \\
\hline $\mathrm{Hg}$ (total) & .004 & $11: 11$ & .0097 & 1.31 & $.0063-0.014$ \\
\hline $\mathrm{K}$ & 20 & $11: 11$ & 760 & 1.3 & $430-1,110$ \\
\hline La -...- & .3 & $3: 11$ & - & -- & $<.3-0.5$ \\
\hline Li & .2 & $2: 11$ & -- & -- & $<.2-0.4$ \\
\hline Mg & .3 & $11: 11$ & 90 & 1.77 & $33-350$ \\
\hline Mn & .2 & $11: 11$ & 9.5 & 1.99 & $2.0-19$ \\
\hline Mo - - & .1 & $11: 11$ & .19 & 1.4 & $.1-0.29$ \\
\hline $\mathrm{Na}$ & 6 & $11: 11$ & 260 & 1.36 & $120-370$ \\
\hline $\mathrm{Nb}$ & 2 & $0: 11$ & -- & -- & $<2-<2$ \\
\hline 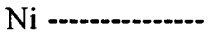 & 1 & $0: 11$ & -- & -- & $<1-<1$ \\
\hline Pb - & .2 & $0: 11$ & -- & -- & $<.2-0.2$ \\
\hline P & 8 & $11: 11$ & 1,780 & 1.31 & $1,100-2,600$ \\
\hline Rb & .01 & $11: 11$ & 1.3 & 1.28 & $.9-1.8$ \\
\hline $\mathrm{Sb}$ & .02 & $0: 11$ & -- & -- & $<.02-<0.02$ \\
\hline Sc & .3 & $0: 11$ & -- & -- & $<.3-<0.3$ \\
\hline Se - - & .2 & $11: 11$ & 1.3 & 1.31 & $.8-1.9$ \\
\hline Sr--.--------------- & .05 & $11: 11$ & 1.6 & 1.97 & $.6-5.1$ \\
\hline Th -.................. & .03 & $0: 11$ & -- & -- & $<.03-0.03$ \\
\hline $\mathrm{Ti}$ & 40 & $0: 11$ & -- & -- & $<40-<40$ \\
\hline $\mathrm{Tl}$ & .003 & $9: 11$ & -- & -- & $<.003-0.005$ \\
\hline U & .02 & $8: 11$ & -- & -- & $<.02-0.27$ \\
\hline V - & .4 & $5: 11$ & -- & -- & $<.4-0.4$ \\
\hline Zn -...-..-- & 5 & $11: 11$ & 12 & 1.36 & $7.8-22$ \\
\hline
\end{tabular}

tissue of fish collected at "background" sites (at some distance from old $\mathrm{Hg}$ mining and refining areas) ranged from less than 0.02 to $0.20 \mathrm{ppm}$ (Gray and others, 1996) (unless specifically stated, these and all subsequent values for fish-tissue material are on a wet-weight basis). In contrast, the $\mathrm{Hg}$ content in the muscle tissue of fish from mineralized areas (and areas downstream of mining activities) ranged from 0.07 to $0.42 \mathrm{ppm}$. Duffy and others (1999) reported a range of 0.079 to $0.16 \mathrm{ppm}$ total $\mathrm{Hg}$ in grayling muscle tissue from the delta region of this watershed. We report observed ranges of 0.021 to $0.15 \mathrm{ppm}$ total $\mathrm{Hg}$ in muscle tissue (GM=0.069 ppm; table 4) and 0.031 to $0.10 \mathrm{ppm}$ total $\mathrm{Hg}$ in liver tissue (GM=0.062; table 5). Total $\mathrm{Hg}$ content in the muscle tissue of grayling from the Fortymile River is therefore somewhat less than what was defined as "background" by Gray and others (2000) but nearly identical to that reported by Duffy and others (1999) for the delta region of the Yukon-Kuskokwim River watershed.

The Fortymile River watershed is not a mineralized area particularly rich in $\mathrm{Hg}$. Gamble and others (2001) reported a maximum of $0.16 \mathrm{ppm} \mathrm{Hg}$ in major local lithologic units, mostly from quartz vein material. The $\mathrm{Hg}$ content in most rock samples was below the LLD of $0.02 \mathrm{ppm}$. Total $\mathrm{Hg}$ content in stream-sediment samples for the Fortymile River study area (fig. 1) ranged from less than 0.02 to $0.30 \mathrm{ppm}$, with a GM value of $0.05 \mathrm{ppm}$, in comparison with a background value of $1.0 \mathrm{ppm}$ reported by Gray and others (2000) in the Kuskokwim River watershed. In addition, integrated surface-water samples from both tributary and Fortymile River main-stem sites were below the LLD of $0.005 \mathrm{ppb}$ (except Steele Creek, which had $0.014 \mathrm{ppb} \mathrm{Hg}$ ). 
The relation between fish weight (a proxy in this study for age) and total $\mathrm{Hg}$ content in muscle tissue is plotted as a simple regression in figure 4 . These data, which conform to those in the general fish literature, indicate that grayling continue to accumulate $\mathrm{Hg}$ in their tissue over time (Hudson and others, 1994), even in a watershed determined to have low levels of bioavailable $\mathrm{Hg}$. We note that the highest total $\mathrm{Hg}$ content measured in our data is nearly an order of magnitude below the Food and Drug Administration (FDA)'s action level (in seafood used for human consumption) of $1.0 \mathrm{ppm} \mathrm{MeHg}$ (U.S. Environmental Protection Agency, 2000).

Finally, the $\mathrm{Hg}$ level in stomach-content material is listed in table 5. The GM value is approximately $0.01 \pm 0.004$ $\mathrm{ppm}$, lower than the range of 0.02 to $0.3 \mathrm{ppm}$ we report for stream sediment from the Fortymile River watershed (but within the experimental variation of the stream-sediment data) or for various lithologic units. $\mathrm{Hg}$-speciation studies are required to ascertain how much of the $\mathrm{Hg}$ content of fish tissue comes from ingested sediment, invertebrates, or the water column.

\section{Other Inorganic Elements}

In addition to $\mathrm{Hg}$, the contents of other inorganic elements in muscle and liver tissue are listed in tables 3 and 4 , respectively. An assessment of the relative importance to this watershed of these elemental concentrations in fish tissue is beyond the scope of this study. However, the Se content of muscle tissue versus fish weight (age) is plotted in figure 4 . Though weak, this negative trend is intriguing because of reports that Se may physiologically inhibit the bioaccumulation of $\mathrm{Hg}$ in fish tissue (Paulsson and Lundbergh, 1991; Chen and others, 2001).

\section{Downstream Biogeochemical Comparisons}

Statistical analysis of the GM values of elemental concentrations in stream-sediment samples indicates that, of the 11 fish-sampling sites, Wilson Creek, South Fork, Moose Creek, and O'Brien Creek appear to differ geochemically the most (Crock and others, 1999, 2000). The locations of these four fish-sampling sites within the study area are shown in figure $3 D$. The Wilson Creek and South Fork fish-sampling sites are within the metavolcanic rocks (unit mv, fig. 1), whereas the Moose Creek and O'Brien Creek fish-sampling sites are within the metasedimentary rocks (unit ms, fig. 1). Unit mv, fine- to medium-grained, dark-green to black amphibolite gneiss of tholeiitic and calc-alkaline affinity, consists chiefly of metabasalt (Day and others, 2000). Many of the minerals that make up these rocks are fairly easily weathered but not especially trace element rich. Unit ms, however, is a relatively easily weathered biotite schist composed of dispersed to massive (60 m thick at one site) sulfide-rich zones (Gamble and others, 2001). Unit ms is more trace element rich than unit mv (Crock and others, 2000). We hypothesize, therefore, that fish chemistry may vary regionally, reflecting the local lithologic geochemistry.

The relative differences in normalized elemental concentrations among the four fish-sampling sites for liver tissue, muscle tissue, and stomach contents are plotted in figures $3 A$, $3 B$, and $3 C$, respectively (see tables $3-5$ ). These results show that liver tissue is the most nearly uniform among the four fish-sampling sites for most elements. $\mathrm{Hg}$, Mo, and Se have the widest observed ranges with no particular site showing consistently the highest or lowest normalized values. Elemental concentrations in muscle tissue appear to vary somewhat more. Of the two tissues, liver shows far more elemental concentrations above the LLDs, and these normalized values generally exceed those measured in muscle tissue (with the notable exception of $\mathrm{Hg}$, which is similar between the two tissues). As is the trend in our data, most metals tend to be concentrated in the liver (and kidneys) as opposed to muscle tissue (Sorensen, 1991).

Stomach contents are of particular interest because they show the greatest intersite variation and because most of the normalized values are larger than those measured in liver or muscle. This result is not surprising because the ingested material contains a considerable amount of sediment. The reason why some elements have normalized values that are actually smaller than those measured in liver or muscle tissue (for example, $\mathrm{Hg}$ and $\mathrm{Se}$ ) is that the concentration of these elements in the quartz-rich sediment is low and the mass of the sediment in the stomach content material "dilutes" the overall concentration of the trace elements.

\section{Quantitative Intersite Comparisons}

We used a $t$ test to quantitatively assess the difference in fish muscle-tissue chemistry between sampling sites along the Fortymile River. Liver tissue and stomach contents were not quantitatively compared because the material collected from individual fish at each of the 11 sampling sites was combined before analysis to give, effectively, only one sample per site. The results of $t$ tests for the elements without censored data $(\mathrm{Cr}, \mathrm{Cs}, \mathrm{Hg}, \mathrm{K}, \mathrm{Mg}, \mathrm{Na}, \mathrm{P}, \mathrm{Rb}$ ) and for the three elements with censored data $(\mathrm{Ca}, \mathrm{Cu}, \mathrm{Se})$ are listed in table 6 ; the $t$ test was not performed on the remaining elements with censored data. For $\mathrm{Ca}, \mathrm{Cu}$, and $\mathrm{Se}$, a value of $0.7 \times \mathrm{LLD}$ was substituted for the censored data as follows: $\mathrm{Ca}(1$ value of $14 \mathrm{ppm}), \mathrm{Cu}(12$ values of $0.35 \mathrm{ppm}$ ), and $\mathrm{Se}$ ( 1 value of $0.14 \mathrm{ppm}$ ) (table 3 ). The $t$ test compared the variation in data among six samples (three from each fish-sampling site, except for O'Brien Creek, where four samples were used). Thus, the comparisons utilized four degrees of freedom among sites using six samples, and five degrees of freedom among sites using seven samples. Only those elements showing significant intersite differences (that is, where $p \leq 0.05$ ) are listed in table 6.

For discussion purposes, the 11 elements listed in table 6 are grouped as major-nutrient elements $(\mathrm{Ca}, \mathrm{K}, \mathrm{Mg}, \mathrm{Na}, \mathrm{P})$, heavy metals or metalloids $(\mathrm{Cr}, \mathrm{Cu}, \mathrm{Hg}, \mathrm{Se})$, and alkali metals 

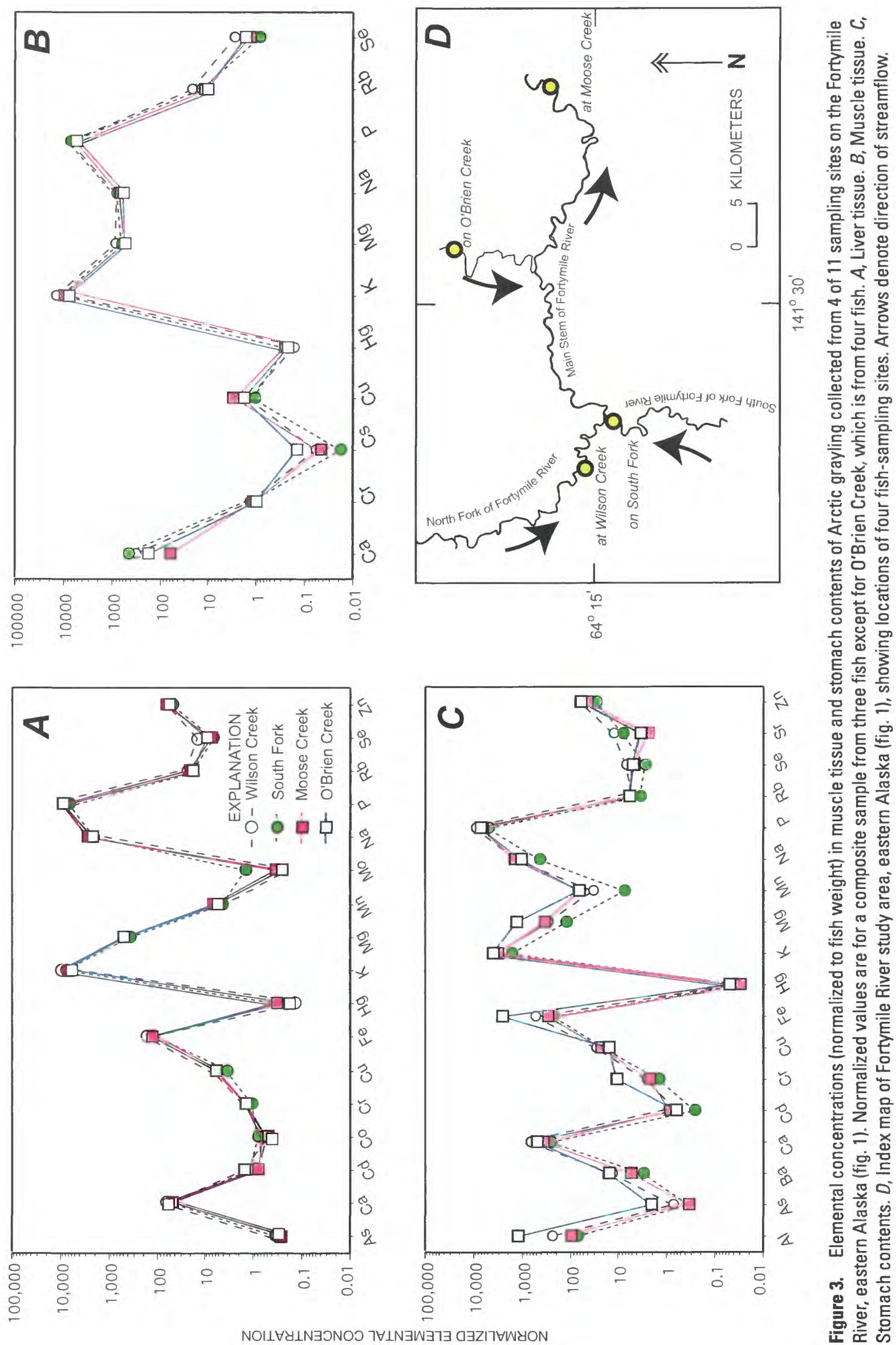
$(\mathrm{Cs}, \mathrm{Rb}$ ), of which the normalized total $\mathrm{Cu}$ and $\mathrm{Rb}$ contents in fish muscle tissue showed no intersite differences.

For heavy metals or metalloids, the normalized total $\mathrm{Cr}, \mathrm{Hg}$, and Se contents differed significantly among five, five, and three fish-sampling sites, respectively (table 6). For example, differences in Se content were noted between fish collected on the South Fork and Canyon Creek, on the South Fork and O'Brien Creek, and on Canyon Creek and O'Brien Creek. These curious differences indicate that the variance in the normalized data (always less than an order of magnitude) for $\mathrm{Hg}, \mathrm{Cr}$, and $\mathrm{Se}$ may be systematic across the landscape and probably not due simply to randomness.

One explanation for the observed systematic differences in fish-muscle-tissue chemistry could be differences in the geochemistry of the feeding sites for these fish. A scatterplot of the normalized data for $\mathrm{Hg}, \mathrm{Cr}$, and $\mathrm{Se}$ does not support the supposition that differences in the geochemistry of local lithologic units are necessarily reflected in differences in fish chemistry. Of course, progressing downstream toward the sites dominated by unit $\mathrm{ms}$, the stream sediment represents more and more of an integration of the geochemistry of the watershed in general.

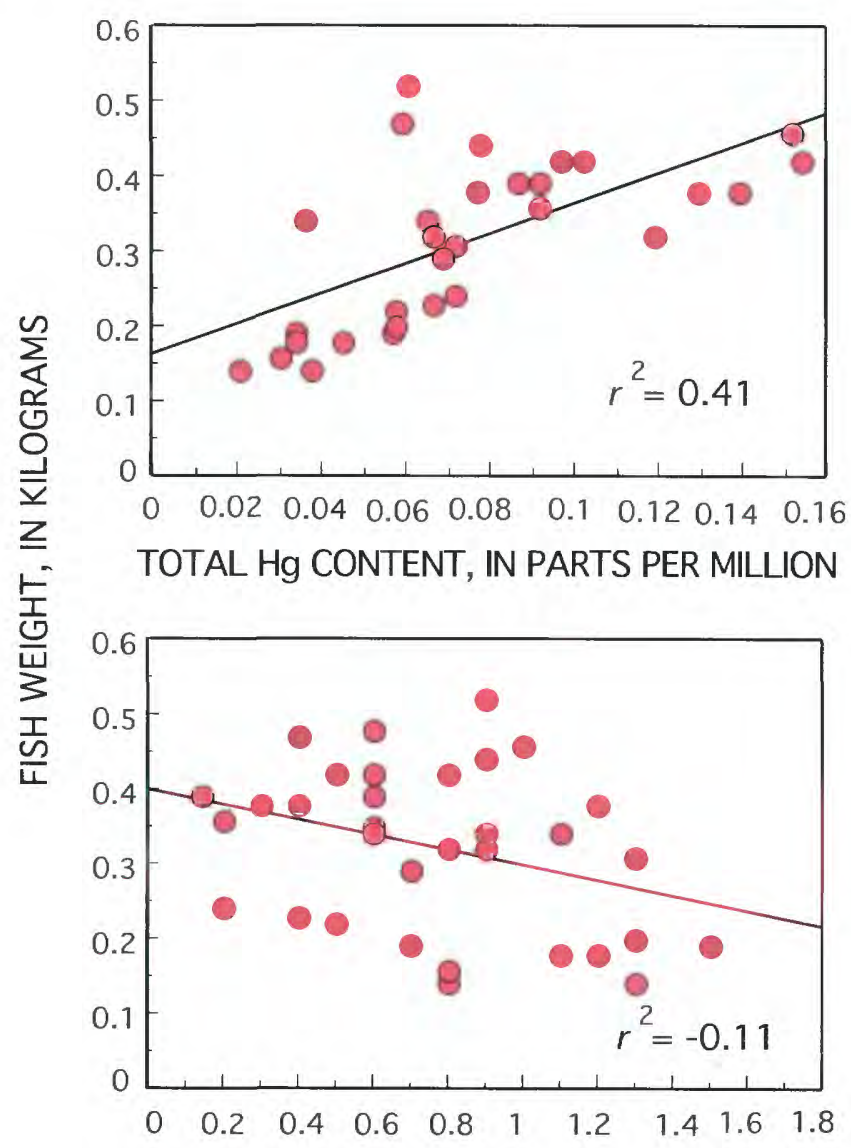

TOTAL Se CONTENT, IN PARTS PER MILLION

Figure 4. Simple regression of fish weight versus total $\mathrm{Hg}$ and Se content in muscle tissue of Arctic grayling collected from the Fortymile River, eastern Alaska (fig. 1).
A couple of interesting exceptions to the observation above are the $\mathrm{Cr}$ and $\mathrm{Se}$ data. The $\mathrm{Cr}$ and $\mathrm{Se}$ contents in the muscle tissue of fish collected from O'Brien Creek differ significantly from those of fish collected from Canyon Creek (table 6). Figure 5 shows that the $\mathrm{Cr}$ and $\mathrm{Se}$ data for these two fish-sampling sites certainly do appear as two distinct populations. (The $t$ test for $\mathrm{Hg}$ between these two fish-sampling sites yielded an important, yet insignificant, $p$ value of 0.08 .) These two fish-sampling sites are within the same area of metasedi-
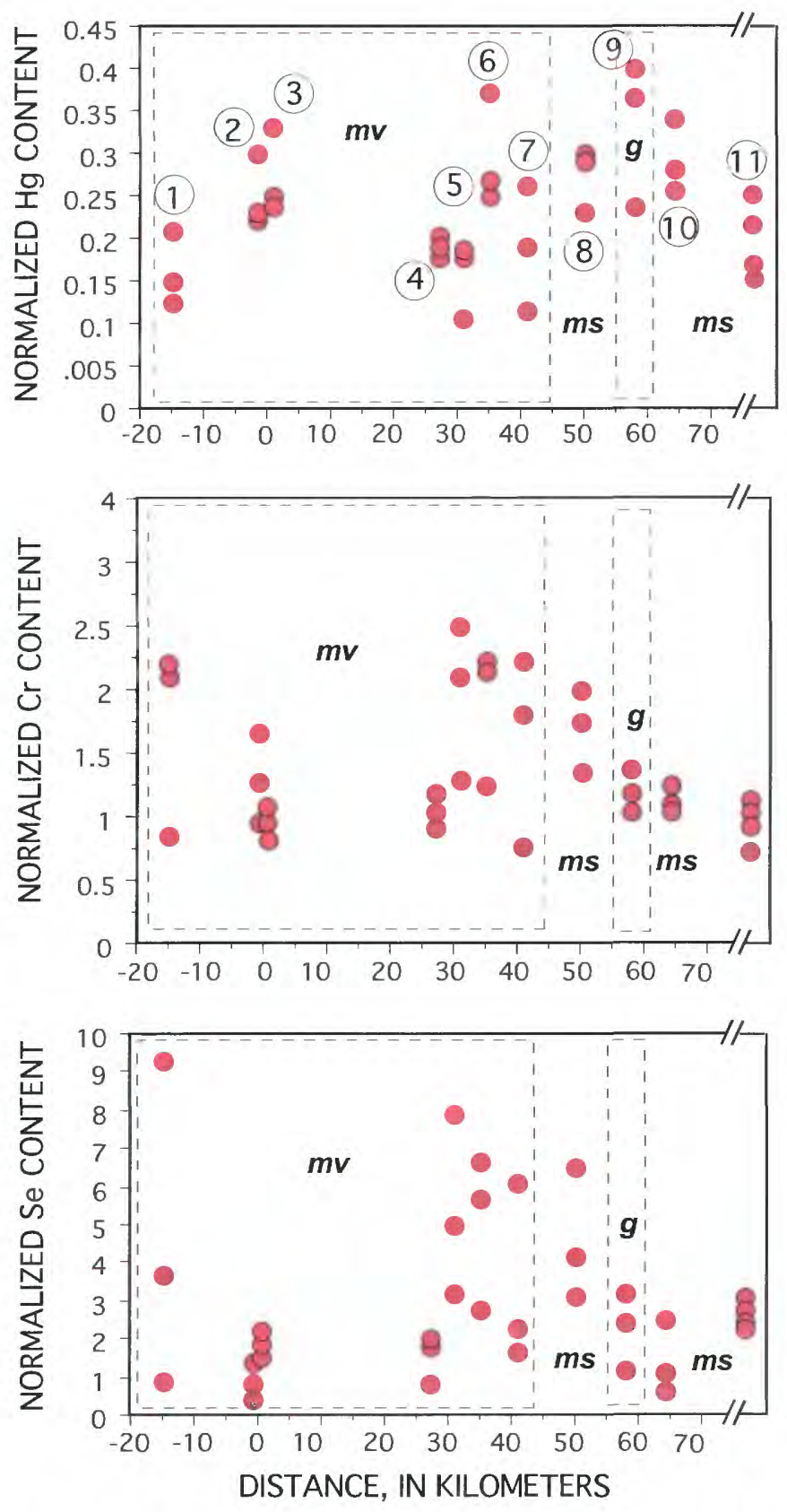

Figure 5. Scatterplots of $\mathrm{Hg}, \mathrm{Cr}$, and Se contents (normalized to fish weight) in muscle tissue of Arctic grayling collected from 11 fish-sampling sites on the Fortymile River, eastern Alaska (numbers, fig. 1; table 1). Distance is measured from confluence of the North and South Forks. See figure 1 for local lithologic units. 
Table 6. Unpaired $t$-test results of a comparison of the elemental concentrations (normalized to fish weight) in the muscle tissue of Arctic grayling collected at 11 fish-sampling sites on the Fortymile River, eastern Alaska.

[See figure 1 for locations. Values in lower left, number of degrees of freedom used in calculations; values in parentheses in upper right, resultant $p$ values. If

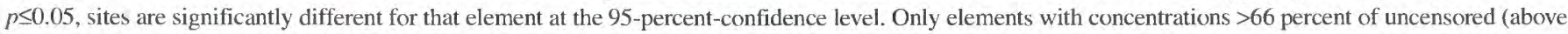
lower limit of detection) analytical values were included in calculations]

\begin{tabular}{|c|c|c|c|c|c|c|c|c|c|c|c|}
\hline & $\begin{array}{l}\text { Wilson } \\
\text { Creek }\end{array}$ & $\begin{array}{c}\text { North } \\
\text { Fork } \\
\text { of the } \\
\text { Fortymile } \\
\text { River }\end{array}$ & $\begin{array}{c}\text { South } \\
\text { Fork } \\
\text { of the } \\
\text { Fortymile } \\
\text { River }\end{array}$ & $\begin{array}{l}\text { Polly } \\
\text { Creek }\end{array}$ & $\begin{array}{l}\text { No-name } \\
\text { creek }\end{array}$ & $\begin{array}{c}\text { Flat } \\
\text { Creek }\end{array}$ & $\begin{array}{l}\text { Steele } \\
\text { Creek }\end{array}$ & $\begin{array}{c}\text { Canyon } \\
\text { Creek }\end{array}$ & $\begin{array}{l}\text { Smith } \\
\text { Creek }\end{array}$ & $\begin{array}{l}\text { Moose } \\
\text { Creek }\end{array}$ & $\begin{array}{c}\text { O'Brien } \\
\text { Creek }\end{array}$ \\
\hline $\begin{array}{l}\text { Wilson } \\
\text { Creek }\end{array}$ & & & & & & & & & & & \\
\hline $\begin{array}{c}\text { North } \\
\text { Fork } \\
\text { of the } \\
\text { Fortymile } \\
\text { River }\end{array}$ & 4 & & & $\mathrm{Na}(0.03)$ & $\begin{array}{l}\mathrm{Hg}(0.05) \\
\mathrm{P}(0.03)\end{array}$ & $\operatorname{Cr}(0.04)$ & & $\begin{array}{l}\mathrm{Cr}(0.03) \\
\mathrm{K}(0.04) \\
\mathrm{Mg}(0.03) \\
\mathrm{Na}(0.04) \\
\mathrm{P}(0.04)\end{array}$ & $\begin{array}{l}\mathrm{Ca} \\
(<0.01)\end{array}$ & $\begin{array}{l}\mathrm{Ca}(0.01) \\
\mathrm{Mg}(0.04)\end{array}$ & \\
\hline $\begin{array}{c}\text { South } \\
\text { Fork } \\
\text { of the } \\
\text { Fortymile } \\
\text { River }\end{array}$ & 4 & 4 & & & & & $\operatorname{Cs}(<0.01)$ & $\begin{array}{l}\text { Cs }(<0.01) \\
\text { Se }(0.05)\end{array}$ & & & $\operatorname{Se}(0.03)$ \\
\hline $\begin{array}{l}\text { Polly } \\
\text { Creek }\end{array}$ & 4 & 4 & 4 & & $\mathrm{P}(0.05)$ & & $\mathrm{Cs}(<0.01)$ & $\begin{array}{l}\mathrm{Cr}(0.05) \\
\mathrm{Cs}(0.01) \\
\mathrm{Hg}(0.02)\end{array}$ & & & \\
\hline $\begin{array}{l}\text { No-name } \\
\text { creek }\end{array}$ & 4 & 4 & 4 & 4 & & $\mathrm{Hg}(0.04)$ & & $\mathrm{Hg}(0.03)$ & $\mathrm{Hg}(0.03)$ & & $\begin{array}{l}\operatorname{Mg}(0.04) \\
P(0.03)\end{array}$ \\
\hline $\begin{array}{c}\text { Flat } \\
\text { Creek }\end{array}$ & 4 & 4 & 4 & 4 & 4 & & & & & & $\operatorname{Cr}(0.03)$ \\
\hline $\begin{array}{l}\text { Steele } \\
\text { Creek }\end{array}$ & 4 & 4 & 4 & 4 & 4 & 4 & & & & & \\
\hline $\begin{array}{c}\text { Canyon } \\
\text { Creek }\end{array}$ & 4 & 4 & 4 & 4 & 4 & 4 & 4 & & $\mathrm{Ca}(0.03)$ & $\begin{array}{l}\mathrm{Ca}(0.04) \\
\mathrm{K}(0.05)\end{array}$ & $\begin{array}{l}\mathrm{Cr}(0.03) \\
\mathrm{K}(0.04) \\
\mathrm{Mg}(0.03) \\
\mathrm{Se}(0.05)\end{array}$ \\
\hline $\begin{array}{l}\text { Smith } \\
\text { Creek }\end{array}$ & 4 & 4 & 4 & 4 & 4 & 4 & 4 & 4 & & $\mathrm{Ca}(0.03)$ & \\
\hline $\begin{array}{l}\text { Moose } \\
\text { Creek }\end{array}$ & 4 & 4 & 4 & 4 & 4 & 4 & 4 & 4 & 4 & & \\
\hline $\begin{array}{l}\mathrm{O}^{\circ} \text { Brien } \\
\text { Creek }\end{array}$ & 5 & 5 & 5 & 5 & 5 & 5 & 5 & 5 & 5 & 5 & \\
\hline
\end{tabular}


mentary rocks. The normalized data among fish at a particular fish-sampling site are remarkably similar. (The data show only slight variation.) For example, figure 5 shows only slight variations in the $\mathrm{Hg}, \mathrm{Cr}$, and Se data for fish-sampling sites 2, 3,10 , and 11 (fig. 1).

The normalized data for fish stomach contents are plotted in figure 6. Just as with the muscle-tissue data, no relation to lithology is noted in these plots of the normalized data for $\mathrm{Hg}$, $\mathrm{Cr}$, and Se. Because of the presence of stream sediment in the ingested material, we anticipated that the stomach-content chemistry might correlate with the stream-sediment chemistry. At 8 of the 11 fish-sampling sites where we collected
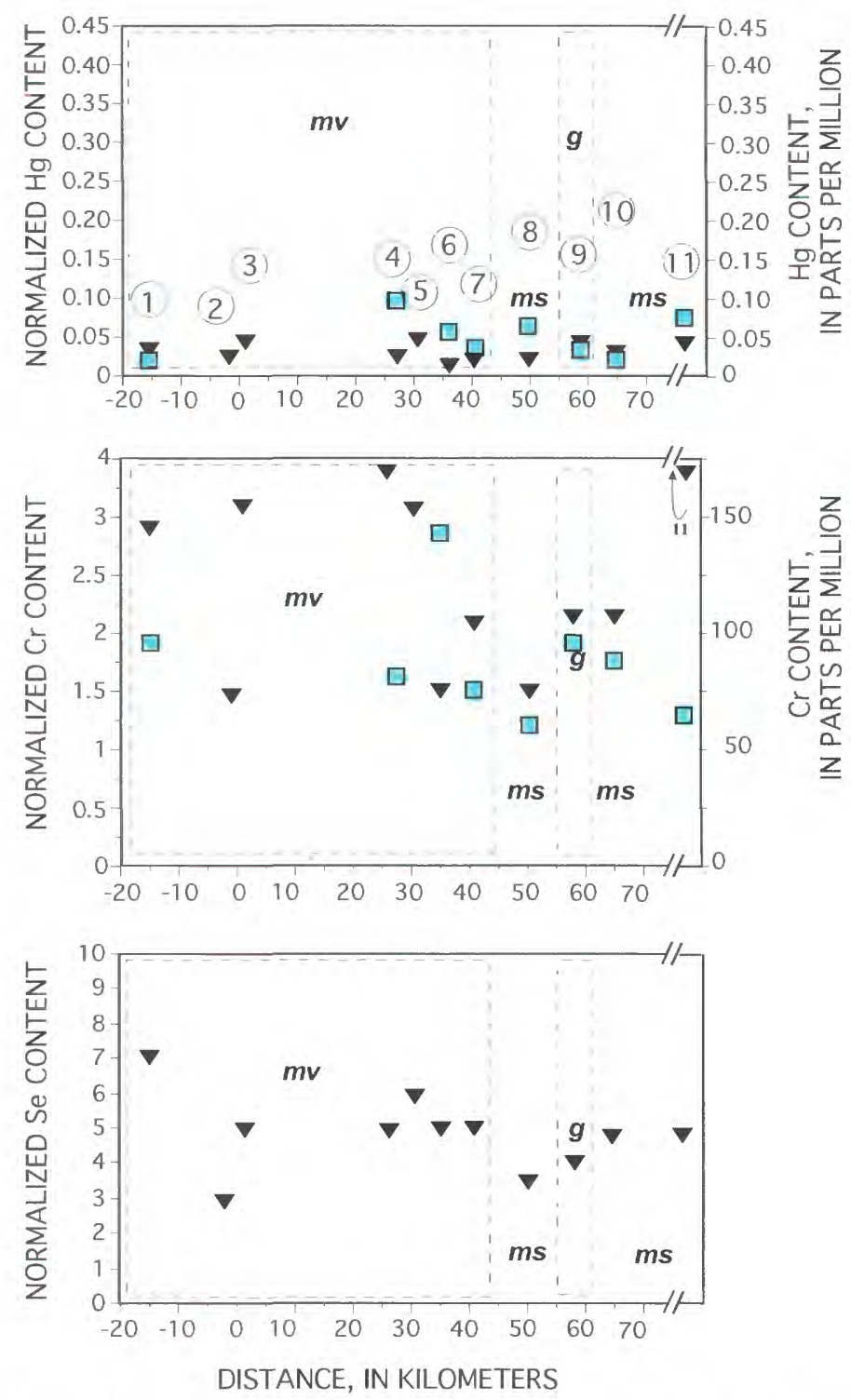

Figure 6. Scatterplots of $\mathrm{Hg}, \mathrm{Cr}$, and Se contents (normalized to fish weight) in stomach contents of Arctic grayling (inverted triangles) and of $\mathrm{Hg}$ and $\mathrm{Cr}$ contents in stream sediment (squares) at 11 fish-sampling sites on the Fortymile River, eastern Alaska (numbers, fig. 1; table 1). Distance is measured from confluence of the North and South Forks. See figure 1 for local lithologic units. samples of both materials (Crock and others, 2000), correlations between the $\mathrm{Hg}$ and $\mathrm{Cr}$ contents in stomach contents and stream sediment are negative ( $r=-0.40$ and -0.17 , respectively). A comparison for $\mathrm{Se}$ is not made because we have no Se data for the stream-sediment samples (fig. 6). In addition, the normalized data for metals or metalloids in stomach contents correlate poorly with those in muscle tissue ( $r=-0.05$, -0.17 , and 0.48 for $\mathrm{Hg}, \mathrm{Cr}$, and $\mathrm{Se}$, respectively), indicating either that the material is not in the gut long enough for element release and absorption, or that the total concentration of the elements in the gut is not indicative of their bioavailability.

\section{Stable-Isotopic Signatures of Grayling Muscle Tissue}

We use stable-isotopic analysis to help explain (1) the trophic level that most closely characterizes the feeding habits of grayling, and (2) the possible relation between metallic-ion contents in fish tissue and the underlying geology. This type of approach has been used successfully to trace the flow of $\mathrm{N}, \mathrm{C}$, and $\mathrm{S}$ through both aquatic and terrestrial ecosystems (Kline and others, 1997; Hobson, 1999). In this study, we first interpret the stable-isotopic data for fish tissue in terms of food source, then we relate those data to the possible influence of the local geologic geochemical signature. For example, if the isotopic signatures indicate that the diet is characteristic of aquatic food sources, then watershed-scale geochemical processes may be most important, and the relation to geology would be less important; whereas if the isotopic signatures indicate that the diet is characteristic of terrestrial food sources, then we might expect a closer local (geologic) geochemical link (signature).

The stable-isotopic ratios of $\mathrm{N}$ and $\mathrm{C}$ have received widespread application in food-web and ecosystem studies (DeNiro and Epstein, 1978, 1981; Minagawa and Wada, 1984; Peterson and Fry, 1987; Hobson, 1999). The stable-isotopic ratios of $\mathrm{S}$ have found more limited application but have been demonstrated to be useful for distinguishing trophic-level relations and migratory habits of fish (Hesslein and others, 1991; Doucett and others, 1999). Thus, stable isotopes offer potentially important insights into the processes of bioaccumulation of metals and other constituents in Arctic grayling from the Fortymile River area.

Stable-isotopic data from muscle tissue for grayling from the Fortymile River are plotted in figure 7 and listed in table 7. The $\mathrm{N}$-isotopic data from our study show only limited variation: the $\delta^{15} \mathrm{~N}$ values for all samples average $8.7 \pm 0.5$ permil $(1 \sigma)$ and range from 7.6 to 9.7 permil. The $\mathrm{C}$-isotopic data vary more widely: the $\delta^{13} \mathrm{C}$ values for all samples average $-29.0 \pm 1.7$ permil $(1 \sigma)$ and range from -33.1 to -25.8 permil. The S-isotopic data vary most widely: the $\delta^{34} \mathrm{~S}$ values for all samples average $1.7 \pm 4.0$ permil $(1 \sigma)$ and range from -8.4 to 8.2 permil.

$\mathrm{N}$ isotopes have been shown to be accurate monitors of trophic level and food sources in food webs. In general, 

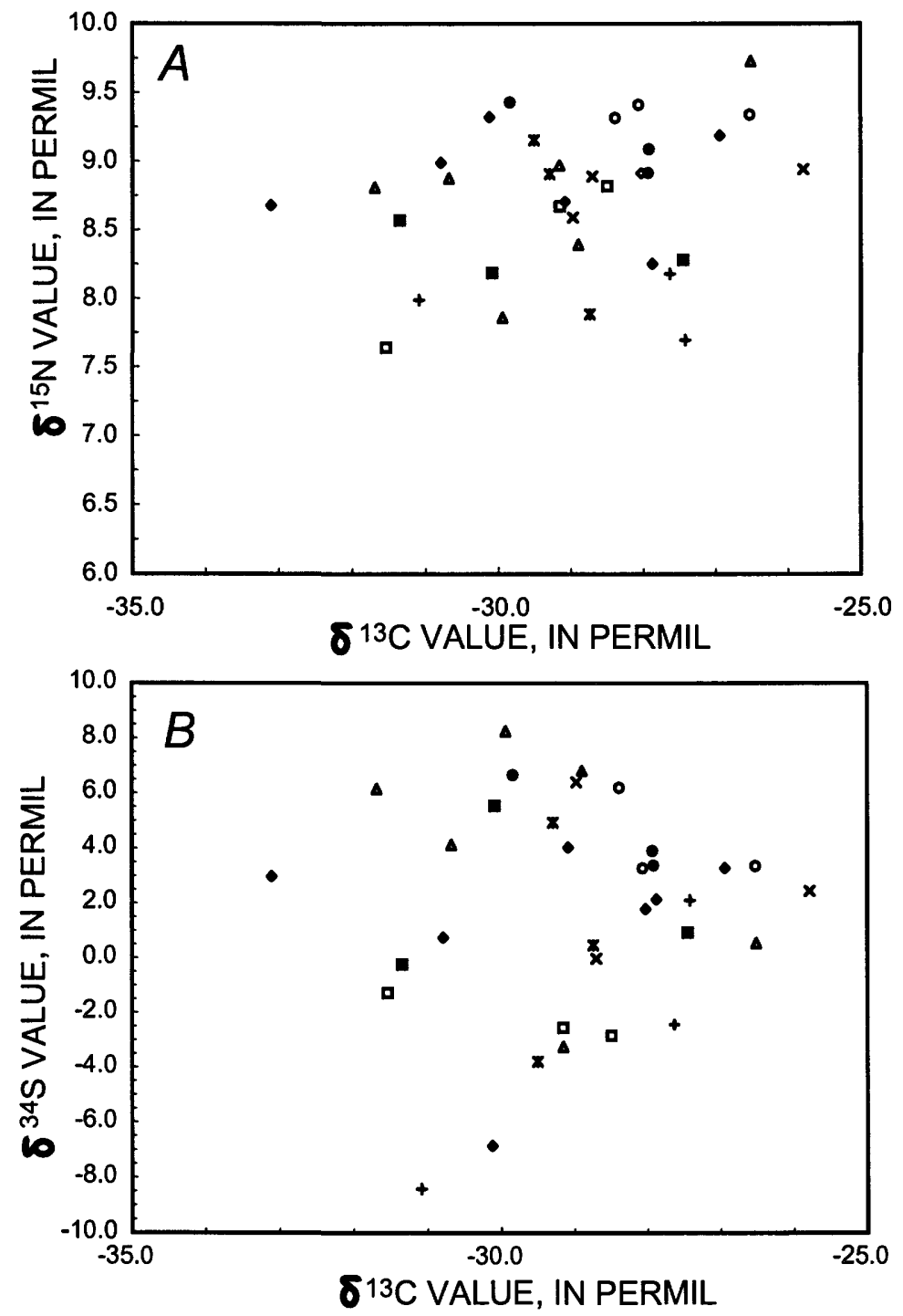

EXPLANATION

- O'Brien Creek

- Canyon Creek

o North Fork River

- Flat Creek

- Moose Creek

$\triangle$ Polly Creek

$x$ Smith Creek

\ South Fork River

* Steele Creek

+ No-name creek

- Wilson Creek

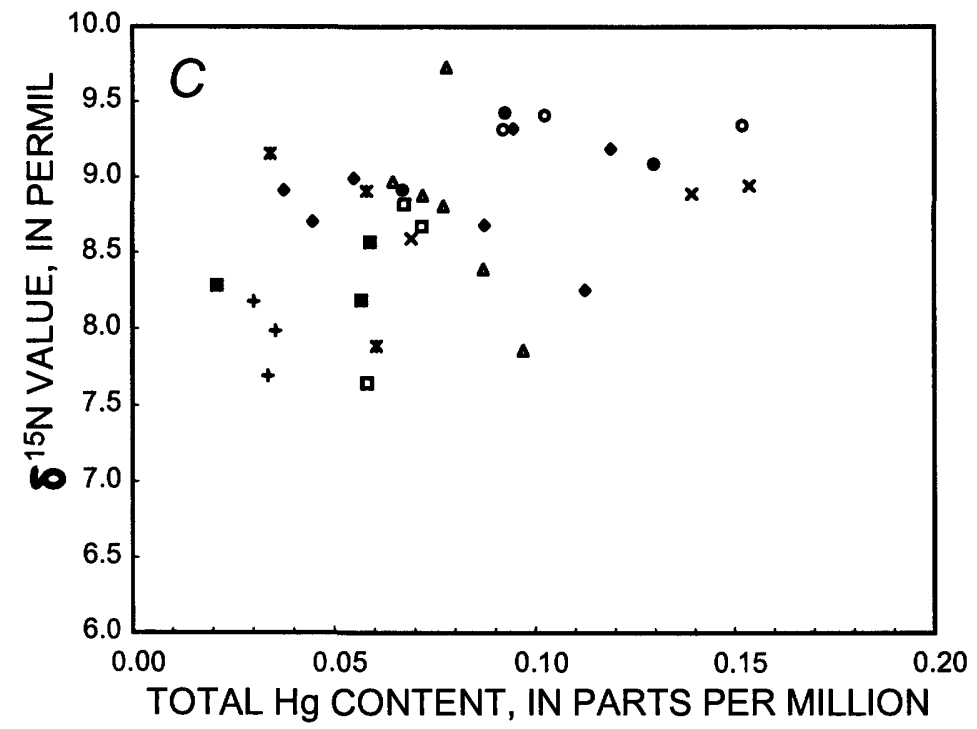

Figure 7. Plots of $\delta^{15} \mathrm{~N}$ versus $\delta^{13} \mathrm{C}$ values, $\delta^{34} \mathrm{~S}$ versus $\delta^{13} \mathrm{C}$ values, and $\delta^{15} \mathrm{~N}$ value versus total $\mathrm{Hg}$ content in muscle tissue of Arctic grayling collected from 11 fish-sampling sites on the Fortymile River, eastern Alaska (fig. 1). 
Table 7. Summary of N-, C-, and S-isotopic data for Arctic grayling collected from the Fortymile River, eastern Alaska.

[See figure 1 for locations. All values in permil]

\begin{tabular}{|c|c|c|c|}
\hline Sample & $\delta^{15} \mathrm{~N}$ & $\delta^{13} \mathrm{C}$ & $\delta^{34} \mathrm{~S}$ \\
\hline Wilson Creek-1 & 8.2 & -30.1 & 5.5 \\
\hline Wilson Creek-2 & 8.6 & -31.4 & -.2 \\
\hline Wilson Creek -3 & 8.3 & -27.4 & .9 \\
\hline Arithmetic mean & 8.3 & -29.6 & 2.1 \\
\hline Standard deviation --- & .2 & 2.0 & 3.0 \\
\hline South Fork-1 & 8.4 & -28.9 & 6.8 \\
\hline South Fork-2 & 7.9 & -29.9 & 8.2 \\
\hline South Fork-3 & 8.9 & -30.7 & 4.1 \\
\hline Arithmetic mean & 8.4 & -29.8 & 6.4 \\
\hline Standard deviation & .5 & .9 & 2.1 \\
\hline North Fork-1 & 9.4 & -28.1 & 3.3 \\
\hline North Fork-2 & 9.3 & -28.4 & 6.2 \\
\hline North Fork-3 & 9.3 & -26.5 & 3.3 \\
\hline Arithmetic mean & 9.4 & -27.7 & 4.3 \\
\hline 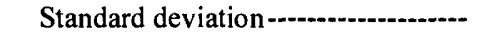 & .0 & 1.0 & 1.7 \\
\hline Polly Creek-1 & 9.7 & -26.5 & .5 \\
\hline Polly Creek-2 & 8.8 & -31.7 & 6.1 \\
\hline Polly Creek-3 & 9.0 & -29.2 & -3.3 \\
\hline Arithmetic mean & 9.2 & -29.1 & 1.1 \\
\hline 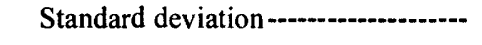 & .5 & 2.6 & 4.7 \\
\hline No-name creek-1 & 7.7 & -27.4 & 2.1 \\
\hline No-name creek-2 & 8.0 & -31.1 & -8.4 \\
\hline No-name creek-3 & 8.2 & -27.6 & -2.4 \\
\hline Arithmetic mean & 8.0 & -28.7 & -2.9 \\
\hline Standard deviation & .2 & 2.1 & 5.3 \\
\hline Flat Creek-1 & 9.2 & -26.9 & 3.3 \\
\hline Flat Creek-2 & 8.7 & -29.1 & 4.0 \\
\hline Flat Creek-3 & 8.9 & -28.0 & 1.8 \\
\hline Arithmetic mean & 8.9 & -28.0 & 3.0 \\
\hline Standard deviation & .2 & 1.1 & 1.1 \\
\hline Steele Creek-1 & 7.9 & -28.7 & .5 \\
\hline Steele Creek-2 & 9.2 & -29.5 & -3.8 \\
\hline Steele Creek-3 & 8.9 & -29.3 & 4.9 \\
\hline Arithmetic mean & 8.6 & -29.2 & .5 \\
\hline Standard deviation & .7 & & 4.4 \\
\hline Canyon Creek-1 & 8.7 & -29.2 & -2.5 \\
\hline Canyon Creek-2 & 8.8 & -28.5 & -2.8 \\
\hline Canyon Creek- 3 & 7.6 & -31.5 & -1.3 \\
\hline Arithmetic mean & 8.4 & -29.7 & -2.2 \\
\hline Standard deviation - & .6 & 1.6 & .8 \\
\hline Smith Creek-1 & 8.9 & -25.8 & 2.5 \\
\hline Smith Creek-2 & 8.6 & -29.0 & 6.4 \\
\hline Smith Creek-3 & 8.9 & -28.7 & .0 \\
\hline Arithmetic mean - & 8.8 & -27.8 & 2.9 \\
\hline Standard deviation - & .2 & 1.8 & 3.2 \\
\hline Moose Creek-1 & 9.4 & -29.8 & 6.7 \\
\hline Moose Creek-2 & 8.9 & -27.9 & 3.9 \\
\hline Moose Creek-3 & 9.1 & -27.9 & 3.4 \\
\hline Arithmetic mean & 9.1 & -28.6 & 4.6 \\
\hline Standard deviation - & .3 & 1.1 & 1.8 \\
\hline O'Brien Creek-1 & 8.3 & -27.9 & 2.2 \\
\hline O'Brien Creek-2 & 8.7 & -33.1 & 3.0 \\
\hline O'Brien Creek-3 & 9.3 & -30.1 & -6.9 \\
\hline O'Brien Creek-4 & 9.0 & -30.8 & .8 \\
\hline Arithmetic mean & 8.8 & -30.5 & -.2 \\
\hline Standard deviation - & .5 & 2.2 & 4.5 \\
\hline Grand arithmetic mean-a............ & 8.7 & -29.0 & 1.7 \\
\hline Grand standard deviation -......- & .5 & 1.7 & 4.0 \\
\hline
\end{tabular}

animal tissues will have a 2 - to 5 -permil increase in $\delta^{15} \mathrm{~N}$ value relative to their diets (DeNiro and Epstein, 1981; Minagawa and Wada, 1984; Peterson and Fry, 1987; Hesslein and others, 1993; Hicks, 1997). Therefore, differences in $\delta^{15} \mathrm{~N}$ values greater than 2 to 5 permil among the tissues of individual fish generally reflect different trophic levels in a food web. Thus, the restricted range of $\delta^{15} \mathrm{~N}$ values for grayling from the Fortymile River, 7.6 to 9.7 permil (fig. $7 \mathrm{~A}$ ), indicates a limited trophic position for these fish, consistent with the dominance of aquatic and terrestrial flies in their guts. The low isotopic mean suggests that the grayling occupy a low trophic level in the Fortymile River watershed ecosystem. Hesslein and others (1991) reported that the $\delta^{15} \mathrm{~N}$ values in the lowest-trophic-level fish (white sucker, ninespine stickleback, juvenile northern pike) from the Lower Mackenzie River Basin, Northwest Territories, Canada, ranged from 6.3 to 9.3 permil. They concluded that the diets of these fish must be dominated by the trophic level occupied by herbivores. Hicks concluded that nonanadromous fish with $\delta^{15} \mathrm{~N}$ values of 5.0 to 9.4 permil represented the trophic level of second-level carnivores (primary predator), a result consistent with the gut contents of the grayling in our study.

$\mathrm{C}$ isotopes have been shown to reflect both food sources and trophic level. Animals generally show a 0.0 - to 2.0 -permil increase in $\delta^{13} \mathrm{C}$ values of their tissues relative to their diets (DeNiro and Epstein, 1978; Peterson and Fry, 1987). Hesslein and others (1993) reported a fractionation between muscle tissue and food of 2.0 permil in their laboratory feeding study of broad whitefish (Coregonus nasus). Thus, the 7.3-permil range in $\delta^{13} \mathrm{C}$ values for grayling from the Fortymile River cannot be due to differences in trophic level because the $\mathrm{N}$-isotopic data indicate that the trophic position of the grayling is confined to a single, restricted level (fig. 7A). Several studies have investigated the $\mathrm{C}$-isotopic fractionation among bulk tissue and such organic compounds as soluble proteins, carbohydrates, and lipids (fats) for various animals (DeNiro and Epstein, 1978; Tieszen and others, 1983; Hilderbrand and others, 1996). In general, the $\mathrm{C}$-isotopic composition of bulk tissue is indistinguishable from that of proteins and carbohydrates, although lipids generally have isotopic compositions 2.5 to 4.5 permil lower than those of bulk tissue. The difference in the fat content in grayling is not considered a likely explanation for the variation in $\mathrm{C}$-isotopic composition because the fish are all similar in size and maturity. In addition, no gender-based differences exist in the $\mathrm{C}$-isotopic compositions of fish that could be attributed to an increase in the reproductive caloric requirements of females; the $\delta^{13} \mathrm{C}$ values in females averages $-29.4 \pm 1.4$ permil $(1 \sigma)$ and of males averages $-28.9 \pm 1.8$ permil $(1 \sigma)$.

The most likely explanation for the variation in the $\mathrm{C}$ isotopic composition of grayling is that the $\delta^{13} \mathrm{C}$ values reflect primary variations in the isotopic composition of food sources for the fish. Hicks (1997) used $\mathrm{N}$ and $\mathrm{C}$ isotopes to elucidate food-web relations in forest and pasture streams in New Zealand. He concluded that the variation in C-isotopic compositions in the lowest levels of the food web reflected mixtures 
of allochthonous and autochthonous $\mathrm{C}$ in the primary producers, on the basis of material analyzed from his study area. Allochthonous $\mathrm{C}$ is derived from terrestrial plants as leaf litter. Terrestrial plants dominantly utilize the $\mathrm{C}_{3}$ photosynthetic pathway to derive their $\mathrm{C}$ from atmospheric $\mathrm{CO}_{2}$, which typically yields $\delta^{13} \mathrm{C}$ values in organic matter of -29 to -26 permil (O'Leary, 1988). Autochthonous $\mathrm{C}$ is produced by aquatic plants, which derive most of their $\mathrm{C}$ from aqueous bicarbonate. Aquatic plant tissue can have $\delta^{13} \mathrm{C}$ values ranging from -40 to -20 permil (Rau, 1980; France, 1995). In the absence of data from primary producers in the Fortymile River watershed, a quantitative assessment of the relative importance of autochthonous and allochthonous $\mathrm{C}$ is difficult because the published range of $\delta^{13} \mathrm{C}$ values for algae ( -40 to -20 permil) overlaps that for allochthonous material ( -30 to -26 permil) and the means of autochthonous ( $-29 \pm 4$ permil) and allochthonous $(-28 \pm 1$ permil) $\mathrm{C}$ are indistinguishable (France, 1995, 1996). Nevertheless, the range of $\delta^{13} \mathrm{C}$ values, from -33.1 to -25.8 permil, for grayling from the Fortymile River is consistent with mixtures of autochthonous and allochthonous $\mathrm{C}$ sources. $\delta^{13} \mathrm{C}$ values outside the range -30 to -26 permil probably represent instream algal $\mathrm{C}$ sources.

S-isotopic compositions of animal tissue are primarily indicative of source (Hesslein and others, 1991; Doucett and others, 1999), because isotopic fractionations associated with trophic-level variations are small (that is, 0.0-1.0 permil per trophic level; Peterson and Fry, 1987). Hesslein and others (1993) attributed isotopic fractionations greater than 1.0 permil in laboratory-raised broad whitefish ( 1.5 permil) to differential assimilation of food components, because no evidence exists for metabolic fractionation of $\mathrm{S}$ isotopes in fish. Because of the limited trophic fractionation of $S$ isotopes, the variation in $\delta^{34} \mathrm{~S}$ values for grayling from the Fortymile River $(-8.4$ to 8.2 permil) must reflect variations in food sources. Doucett and others (1999) reported a similar variation in $\delta^{34} \mathrm{~S}$ values for brook trout in New Brunswick, Canada (1.5-14.1 permil). Hesslein and others (1991) reported a variation in $\delta^{34} \mathrm{~S}$ values of -8 to 3 permil for broad whitefish from the Lower Mackenzie River Basin, Northwest Territories, Canada. However, the higher $\delta^{34} S$ values reported in both of these studies were attributed to the elevated $\delta^{34} S$ value of marine sulfate $(\sim 21$ permil), in combination with the anadromous behavior of broad whitefish and brook trout. For nonanadromous grayling from the Fortymile River, the range of $\delta^{34} \mathrm{~S}$ values must reflect an isotopically heterogeneous local food supply (fig. 7B).

$\mathrm{S}$ isotopes are expected to have the closest links to the underlying geology of the Fortymile River watershed relative to $\mathrm{N}$ and $\mathrm{C}$. Igneous rocks, siliciclastic marine sedimentary rocks, and marine evaporites all have reasonably well constrained ranges of isotopic compositions. The $\delta^{34} \mathrm{~S}$ values of igneous rocks generally range from 0 to 5 permil, those of siliciclastic sedimentary rocks are generally negative and average -20 permil, and those of Lower Paleozoic marine evaporites range from 16 to 33 permil (Ohmoto and Rye, 1979; Seal and others, 2000). Because the $\delta^{34} S$ values of grayling range from significantly negative $(-8.4$ permil) to significantly posi- tive ( 8.2 permil), and because of the geologic setting of the study area, all three lithologic reservoirs (fig. 1; table 1) may be important in the Fortymile River Basin.

In a laboratory feeding study of broad whitefish (Hesslein and others, 1993), N-, C-, and S-isotopic changes were modeled in response to feeding with an isotopically distinct food. The modeling was reflective of two processes: tissue addition (growth) and metabolic tissue replacement. Hesslein and others, 1993 reported that the half-time for replacement of $\mathrm{N}, \mathrm{C}$, and $\mathrm{S}$ associated with growth was on the order of a few months, whereas that associated with metabolic replacement was more than a year. Thus, for natural populations, which are slow growing relative to laboratory conditions, several years may be required to equilibrate with a new food source. Therefore, in slow-growing natural populations, isotopic differences among individuals in a group should reflect differences in food choices.

From the perspective of grayling in the Fortymile River, the $\mathrm{N}$-, C-, and S-isotopic signatures probably reflect longerterm feeding habits because of the long turnover time for metabolic replacement. Thus, the $\mathrm{N}$-isotopic data reflect a consistent and restricted, long-term trophic position for the fish. In contrast, the $\mathrm{C}$ - and $\mathrm{S}$-isotopic signatures of the fish record diverse and heterogeneous food sources. For example, the four fish from the O'Brien Creek sampling site span 71 percent of the total $\mathrm{C}$-isotopic range and 60 percent of the total S-isotopic range observed for all fish (fig. $7 B$ ). Other sampling sites show similar wide observed ranges. Furthermore, the nonlinear scatter suggests that the population is feeding on a minimum of three distinct food components. In addition, individual fish are probably exhibiting a high degree of long-term selectivity in food choices, because the isotopic differences reflect long-term feeding habits due to the slow rates of metabolic replacement of muscle tissue. This conclusion is somewhat remarkable because of the interyear fidelity of grayling to summer-feeding and overwintering sites (Reynolds, 1997; Buzby and Deegan, 2000), which would tend to decrease the isotopic variation in potential food sources. Causes for the observed isotopic variations include differences in overwintering sites for individual fish caught at a specific sampling site, individual preferences in diet for aquatic or terrestrial invertebrates, and shortened isotopic turnover times.

Aquatic invertebrates dominate the stomach contents of grayling from Steele Creek (69 percent) and Polly Creek (66 percent), whereas terrestrial invertebrates dominate the stomach contents of grayling from Canyon Creek ( 77 percent; table 8). In addition, the grayling from the Polly Creek sampling site show a lower percentage of dominant taxa in their stomach content (29 percent) than do those from the Steele Creek sampling site (61 percent) and the Canyon Creek sampling site (55 percent). Thus, the stomach contents minimally show a short-term diversity in the food sources for grayling.

The feeding habits recorded in the isotopic signatures may actually represent shorter-term behavior than the multiyear periods required to equilibrate with new food sources through metabolic tissue replacement. Because grayling feed aggressively during the summer, their isotopic signatures 
Table 8. Summary of dominant invertebrate taxa identified in the stomach contents of three Arctic grayling collected at fish-sampling sites along the main stem of the Fortymile River, eastern Alaska.

[See figure 1 for locations. Insect orders: Diptera, Ephemeroptera, Plecoptera, and Trichoptera; insect family: Chironomidae. EPT, combined Ephemeroptera-Plecoptera-Trichoptera. Do., ditto]

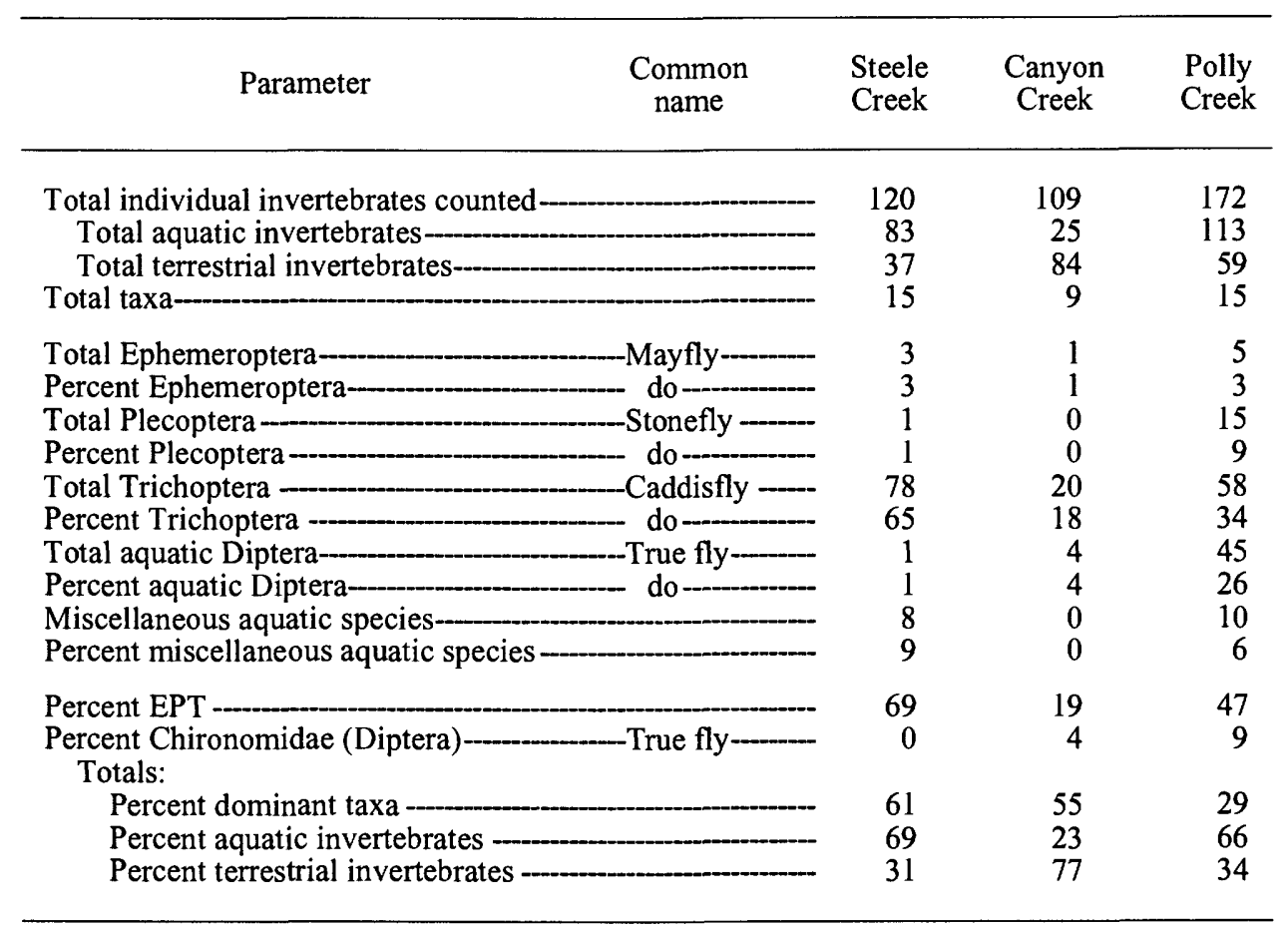

may equilibrate with local food sources if significant growth accompanies summer feeding. If so, then the feeding period recorded by the stable-isotopic composition of muscle tissue will probably fall between the several months inferred for rapid growth, and the several years inferred for metabolic tissue replacement. In either case, reliance on aquatic invertebrates, particularly larval forms, would be expected to have a homogenizing effect on the stable-isotopic signatures in grayling found in the main stem of the Fortymile River. In contrast, reliance on terrestrial invertebrates would be expected to cause a greater variation in stable-isotopic signatures because of local variations in geology and land cover.

The diversity in the stable-isotopic data help explain the weak correlation between the metallic-ion contents in fish tissue and the underlying geology. Stable-isotopic data can be interpreted in terms of the varying mixing of food sources that incorporate aquatic sources (which reflect watershed-scale geochemical signatures) and terrestrial sources (which may reflect a more local or geologic geochemical signature). Mixing of multiple components is unlikely to show simple correlations with local geology. $\mathrm{Hg}$ is documented to bioaccumulate in the muscle tissue of higher organisms, and $\mathrm{N}$ isotopes monitor trophic position. Examination of the interdependence of $\mathrm{Hg}$ content and $\delta^{15} \mathrm{~N}$ value in the grayling samples reveals a poor correlation and no systematic intersite variation $\left(r^{2}=0.179\right.$; fig. $7 C$ ), consistent with the idea that the grayling are tapping into varied food sources.

\section{Composition of Grayling Stomach Contents}

The stomachs and upper intestines of the three Arctic grayling analyzed were fully distended-that is, feeding success appeared to be high. Invertebrates were identified in material from the anterior part of the stomach and, when key characteristics remained, in other, more digested material from the posterior part of the stomach and the intestine (table 9).

We identified 109 to 172 individual invertebrates from each of the fish and from 9 to 15 distinct taxonomic groups (generally to family level, although some specimens contained sufficient remaining characteristics to identify to genus level; see Crock and others, 2003, table 8). The fish stomachs from the Steele and Polly Creek sampling sites contained high proportions (47-69 percent) of EPT taxa. In contrast, the proportion of EPT taxa in the Canyon Creek fish was only 19 percent. This difference in the proportion of EPT taxa indicates that food sources vary somewhat with location on the river; fewer EPT taxa reflect the lower proportion of aquatic taxa observed in the Canyon Creek sampling-site population.

Most of the invertebrates counted in fish from the Steele and Polly Creek sites were well-developed aquatic Trichoptera larvae. Similarly, 61 percent of the total invertebrates identified in Steele Creek fish stomachs were Trichoptera (genus Arctopsyche). In contrast, only 29 percent of the invertebrates identified in the Polly Creek fish were Trichoptera (genus Micrasema). The stomach contents contained many wings 
Table 9. Numbers of aquatic and terrestrial invertebrate taxa identified in three Arctic grayling individuals collected from sampling sites on the main stem of the Fortymile River, eastern Alaska.

[Form: A, aquatic; $\mathrm{T}$, terrestrial]

\begin{tabular}{|c|c|c|c|c|c|c|c|}
\hline \multirow{2}{*}{$\begin{array}{l}\text { Order } \\
\text { (common name) }\end{array}$} & \multirow{2}{*}{ Family } & \multicolumn{2}{|c|}{$\begin{array}{l}\text { Anterior } \\
\text { stomach }\end{array}$} & \multicolumn{2}{|c|}{$\begin{array}{l}\text { Posterior } \\
\text { stomach }\end{array}$} & \multicolumn{2}{|c|}{$\begin{array}{l}\text { Lower } \\
\text { intestine }\end{array}$} \\
\hline & & A & $\mathrm{T}$ & A & $\mathbf{T}$ & A & $\mathbf{T}$ \\
\hline \multicolumn{8}{|c|}{ Male fish (406 mm long) collected at the Steele Creek confluence } \\
\hline $\begin{array}{l}\text { Ephemeroptera } \\
\text { (mayfly). }\end{array}$ & 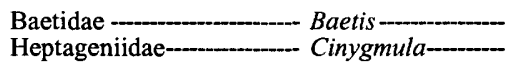 & $-\frac{-}{1}$ & -- & $\begin{array}{r}2 \\
--\end{array}$ & $\begin{array}{l}-- \\
--\end{array}$ & $\begin{array}{l}-- \\
--\end{array}$ & -- \\
\hline $\begin{array}{l}\text { Plecoptera } \\
\text { (stonefly). }\end{array}$ & Unidentified - & -- & 1 & -- & -- & -- & -- \\
\hline $\begin{array}{l}\text { Trichoptera } \\
\text { (caddisfly). }\end{array}$ & $\begin{array}{l}\text { Brachycentridae - }- \text { Brachycentrus } \\
\text { Hydropsychidae - }\end{array}$ & $\begin{array}{r}2 \\
18\end{array}$ & -- & $\begin{array}{r}3 \\
55\end{array}$ & $\begin{array}{l}-- \\
--\end{array}$ & -- & - \\
\hline $\begin{array}{l}\text { Coleoptera } \\
\text { (beetle). }\end{array}$ & 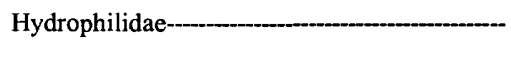 & 1 & -- & -- & 1 & -- & -- \\
\hline $\begin{array}{l}\text { Diptera } \\
\text { (true fly). }\end{array}$ & $\begin{array}{l}\text { Ceratopogonidae } \\
\text { Chironomidae (adult) } \\
\text { Simuliidae (larvae) } \\
\text { Tipulidae }\end{array}$ & $\begin{array}{l}-- \\
-- \\
-- \\
1\end{array}$ & $\begin{array}{r}10 \\
8 \\
5 \\
--\end{array}$ & $\begin{array}{l}-- \\
-- \\
-- \\
--\end{array}$ & $\begin{array}{l}-- \\
-- \\
-- \\
--\end{array}$ & $\begin{array}{l}-- \\
-- \\
-- \\
--\end{array}$ & $\begin{array}{l}-- \\
-- \\
-- \\
--\end{array}$ \\
\hline $\begin{array}{l}\text { Homoptera } \\
\text { (leafhopper). }\end{array}$ & Cicadellidae - & -- & 1 & -- & -- & -- & -- \\
\hline $\begin{array}{l}\text { Hemiptera } \\
\text { (water boatman). }\end{array}$ & 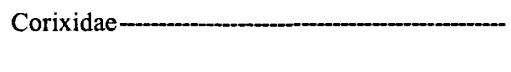 & -- & -- & - & 1 & -- & -- \\
\hline $\begin{array}{l}\text { Hymenoptera } \\
\text { (wasp). }\end{array}$ & $\begin{array}{l}\text { Unidentified - } \\
\text { Ichneumonidae }\end{array}$ & -- & $\begin{array}{l}1 \\
8\end{array}$ & $\begin{array}{l}-- \\
--\end{array}$ & $\begin{array}{l}-- \\
--\end{array}$ & $\begin{array}{l}-- \\
--\end{array}$ & $\overline{--}$ \\
\hline $\begin{array}{l}\text { Arachnida } \\
\text { (spider) }\end{array}$ & - & -- & 1 & -- & -- & - & - \\
\hline
\end{tabular}

\begin{tabular}{|c|c|c|c|c|c|c|c|}
\hline \multicolumn{8}{|c|}{ Female fish ( $360 \mathrm{~mm}$ long) collected at the Canyon Creek confluence } \\
\hline $\begin{array}{l}\text { Ephemeroptera } \\
\text { (mayfly). }\end{array}$ & 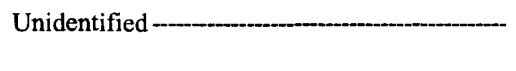 & 1 & -- & -- & -- & -- & -- \\
\hline $\begin{array}{l}\text { Trichoptera } \\
\text { (caddisfly). }\end{array}$ & 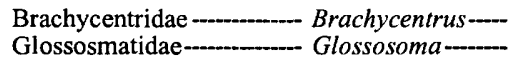 & $\begin{array}{l}18 \\
--\end{array}$ & - & -- & - & $\begin{array}{l}1 \\
1\end{array}$ & - \\
\hline $\begin{array}{l}\text { Diptera } \\
\text { (true fly). }\end{array}$ & $\begin{array}{l}\text { Chironomidae (pupa) } \\
\text { Chironomidae (adult) }\end{array}$ & $\begin{array}{r}4 \\
--\end{array}$ & $\frac{--}{20}$ & $\begin{array}{l}-- \\
--\end{array}$ & $\overline{40}$ & -- & -- \\
\hline $\begin{array}{l}\text { Homoptera } \\
\text { (leafhopper). }\end{array}$ & $\begin{array}{l}\text { Unidentified - } \\
\text { Cicadellidae - }\end{array}$ & $\begin{array}{l}-- \\
--\end{array}$ & $\begin{array}{r}20 \\
1\end{array}$ & $\begin{array}{l}-- \\
--\end{array}$ & -- & -- & -- \\
\hline $\begin{array}{l}\text { Hymenoptera } \\
\text { (wasp). }\end{array}$ & 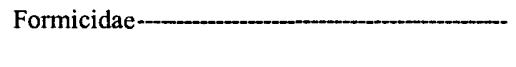 & -- & 3 & -- & -- & -- & -- \\
\hline $\begin{array}{l}\text { Thysanoptera } \\
\text { (thrip). }\end{array}$ & Mymicinae-_-_- & -- & 1 & -- & -- & -- & -- \\
\hline \multicolumn{8}{|c|}{ Male fish (340 mm long) collected at the Polly Creek confluence } \\
\hline $\begin{array}{l}\text { Ephemeroptera } \\
\text { (mayfly). }\end{array}$ & 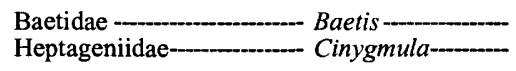 & $\begin{array}{l}3 \\
2\end{array}$ & -- & -- & -- & -- & -- \\
\hline $\begin{array}{l}\text { Plecoptera } \\
\text { (stonefly) }\end{array}$ & $\begin{array}{l}\text { Capniidae } \\
\text { Nemouridae }-1\end{array}$ & $\begin{array}{r}2 \\
--\end{array}$ & -- & $\begin{array}{r}3 \\
--\end{array}$ & -- & -- & - \\
\hline $\begin{array}{l}\text { Trichoptera } \\
\text { (caddisfly). }\end{array}$ & $\begin{array}{l}\text { Brachycentridae -_-_- Brachycentrus - }-1 \\
\text { Brachycentridae - } \\
\text { Hydropshchidae }\end{array}$ & $\begin{array}{r}5 \\
10 \\
3\end{array}$ & -- & $-\overline{15}$ & $\begin{array}{l}-- \\
-- \\
--\end{array}$ & $\begin{array}{c}-\overline{2} \\
25 \\
--\end{array}$ & $\begin{array}{l}-- \\
-- \\
--\end{array}$ \\
\hline $\begin{array}{l}\text { Coleoptera } \\
\text { (beetle). }\end{array}$ & 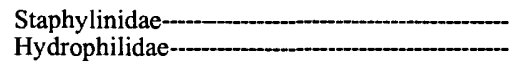 & - & $\begin{array}{l}1 \\
3\end{array}$ & -- & -- & -- & -- \\
\hline $\begin{array}{l}\text { Diptera } \\
\text { (true fly). }\end{array}$ & $\begin{array}{l}\text { Unidentified - } \\
\text { Chironomidae (pupa) } \\
\text { Simuliidae (pupa) } \\
\text { Culicidae }\end{array}$ & $\begin{array}{l}-- \\
10 \\
15 \\
--\end{array}$ & $\begin{array}{l}25 \\
--\overline{-} \\
10\end{array}$ & $\begin{array}{l}-- \\
-- \\
20 \\
--\end{array}$ & $\begin{array}{l}-- \\
-- \\
-- \\
--\end{array}$ & $\begin{array}{l}-- \\
-- \\
-- \\
--\end{array}$ & $\begin{array}{l}-- \\
-- \\
-- \\
--\end{array}$ \\
\hline $\begin{array}{l}\text { Hymenoptera } \\
\text { (wasp). }\end{array}$ & $\begin{array}{l}\text { Ichneumonidae } \\
\text { Mymanidae }\end{array}$ & -- & $\begin{array}{l}3 \\
5\end{array}$ & $\begin{array}{l}-- \\
--\end{array}$ & 1 & -- & -- \\
\hline
\end{tabular}


that appeared to be from emerging winter stoneflies (likely Nemouridae). These invertebrates were not counted as part of the sample because they could not be positively identified; however, we estimated about 75 to 100 wing pairs.

As stated above, the fish from the Canyon Creek sampling site contained the highest proportion of terrestrial insects, mostly Homoptera (18 percent of the total counted) and adult Chironomidae ( 55 percent). Only 18 percent of the invertebrates were Trichoptera, most of which were Brachycentridae (genus Brachycentrus).

\section{Summary and Conclusions}

1. We present quantitative information on the chemistry of 38 elements in the muscle tissue, liver, and stomach contents of Arctic grayling collected from the lower reaches of the Fortymile River watershed. We also present $\mathrm{N}-, \mathrm{C}-$, and $\mathrm{S}$-isotopic data for fish muscle tissue. These data can be used as estimates of biogeochemical baselines for grayling in this region of Alaska.

2. Although interyear feeding-site fidelity is known to be high for grayling, and although differences in the chemistry of fish tissue can be quantitatively demonstrated between fish-sampling sites, this variation is not directly attributable to intersite lithologic differences, possibly because the total chemistry of stomach contents is an inadequate measure of element bioavailability (that proportion of the total amount present which is finally incorporated into fish tissue). The poor correlation between lithology and fish chemistry may also be due to the low "geoavailability" of elements within minerals that make up the metasedimentary and metavolcanic rocks-that is, the common minerals, such as feldspar, mica, hornblende, and so on, would not be easily weathered in this environment, where ground and surface waters are most commonly circumneutral in $\mathrm{pH}$. Wang and others (see chap. 1) report subtle differences in the rare-earth-element signatures of waters that drain various lithologic units within the Fortymile River watershed. Streams draining the Steele Creek tonalite were found to have low major-ion concentrations, whereas those draining metasedimentary-rock units had higher $\mathrm{Cu}$ and $\mathrm{Cr}$ contents. No systematic variation in $\mathrm{Hg}$ content with lithology was observed. Finally, the slight variation in the geochemistry of major lithologic units and stream sediment, coupled with the limited areal extent of the lithologic units, might not result in enough of a geochemical imprint on the landscape to be reflected in fish-tissue chemistry.

3. Macalady and others (see chap. 3) found that the abundant dissolved natural organic matter (NOM) in water from the Fortymile River main stem and O'Brien Creek sequesters some cationic metals in solution. From a comparison of the binding ability of these NOM-rich waters with those of streams from other parts of the globe, however, this process probably has a minimal role in the mobilization of metallic ions in these two Alaskan streams.

4. The results of a $t$-test comparison of the variation in the concentrations of 12 elements in fish muscle tissue collected among the 11 sampling sites showed significant differences between at least 2 sites for 10 of these elements. This nonrandom, possibly systematic pattern is a direct function of the slight variation in the data for fish collected at individual sites. We compare this "clustering" of values within samples at a given fish-sampling site with the greater intersite variation in the data. This intersite variation is not attributable to specific lithologic units (see above) but may be due to as-yet-undetermined differences in site geochemistry and element bioavailability.

5. Although the low Hg content in fish tissue is not surprising, the importance of analyzing for $\mathrm{Hg}$ in this watershed is driven by a concern over its use, since the 1890 s, in gold amalgamation by placer miners in the region. The evaluation of $\mathrm{Hg}$ contamination in Arctic and subarctic aquatic and terrestrial ecosystems certainly deserves closer scrutiny because of the general global $\mathrm{Hg}$ concern and a growing appreciation for the unique cycling of $\mathrm{Hg}$ between ecosystems and the atmosphere in Arctic regions (Schroeder and others, 1998; Betts, 2001). Total Hg content in muscle tissue ranged from 0.021 to $0.15 \mathrm{ppm}$ (wet-weight basis), with a GM value of $0.069 \mathrm{ppm}$, and in liver tissue from 0.031 to $0.10 \mathrm{ppm}$, with a GM value of $0.062 \mathrm{ppm}$. The total $\mathrm{Hg}$ content in muscle tissue of grayling from the Fortymile River are nearly an order of magnitude below the FDA's action level of $1.0 \mathrm{ppm} \mathrm{MeHg}$ in fish and well below the U.S. Environmental Protection Agency's risk-based concentration of 0.14 or 0.30 $\mathrm{mg} / \mathrm{kg}$ (maximum daily consumption). In addition, the concentrations of other metals and metalloids in muscle tissue are low relative to published values for many diverse freshwater and marine fish.

6. The $\mathrm{N}$-isotopic signatures of fish muscle tissue indicate a restricted trophic position for the grayling population, consistent with their stomach contents and known feeding habits. The $\mathrm{C}$ - and S-isotopic data indicate selectivity in feeding habits for individual fish. The diversity in the stable-isotopic data helps explain the weak correlation between metallic-ion contents in fish tissue and the underlying geology. Stable-isotopic data can be interpreted in terms of a mixing of food sources that incorporate aquatic sources, which reflect watershed-scale geochemical signatures, and terrestrial sources, which may reflect a more local (geologic) geochemical signature.

7. Stomach contents from three grayling (collected 1 year after, but at the same time of year as, the biogeochemical samples) showed an incredible number of invertebrate individuals and diversity of invertebrate taxa. 
From 109 to 172 individual invertebrates were separated and cataloged from the three fish, representing from 9 to 15 distinct taxa. The proportion of EPT taxa varied with fish-sampling site on the river, indicating variation in either feeding habits or, more probably, available taxa. Fewer EPT taxa reflect a lower proportion of aquatic forms relative to terrestrial forms. These data indicate that the river has a diverse food web which is being effectively exploited by the resident grayling. A complete listing of invertebrate taxa identified for each of the three individual fish examined was given by Crock and others (2003).

\section{Acknowledgments}

We thank Larry and June Taylor of the Fortymile Mining District for their hospitality, good humor, and the second collection of fish stomachs. Chemical analyses were performed in the USGS laboratories in Denver, Colo., by Z.A. Brown, A.L. Meier, and P.M. Theodorakos, and isotopic analyses in the USGS laboratories in Reston, Va., by G.A. Wandless. Johanna Crock assisted with the preparation of fish samples.

\section{References Cited}

Betts, K.S., 2001, Arctic may be naturally generating reactive gaseous mercury: Environmental Science and Technology, v. 35 , p. $434-435$.

Buzby, K.M., and Deegan, L.A., 2000, Inter-annual fidelity to summer feeding sites in Arctic grayling: Environmental Biology of Fishes, v. 59, p. 319-327.

CEM Corp., 1994, Microwave-assisted acid digestion of biological tissue, application note BI-3 of Applications manual for the CEM microwave sample preparation system: Matthews, N.C.

Chen, Y.-W., Belzile, Nelson, and Gunn, J.M., 2001, Antagonistic effect of selenium and mercury assimilation by fish populations near Sudbury metal smelters: Limnology and Oceanography, v. 46, p. 1814-1818.

Crock, J.G., Gough, L.P., Wanty, R.B., Day, W.C., Wang, Bronwen, Gamble, B.M., Henning, M.W., Brown, Z.A., and Meier, A.L., 1999, Regional geochemical results from the analyses of rock, water, soil, stream sediment, and vegetation samples-Fortymile River watershed, east-central Alaska: U.S. Geological Survey Open-File Report 99-33, 82 p.

Crock, J.G., Gough, L.P., Wanty, R.B., Day, W.C., Wang, Bronwen, Gamble, B.M., Henning, M.W., Brown, Z.A., and Meier, A.L., 2000, Regional geochemical results from the analyses of rock, water, soil, stream sediment, and vegeta- tion samples-Fortymile River watershed, east-central Alaska, 1998 sampling: U.S. Geological Survey Open-File Report 00-511, 157 p.

Crock, J.G., Seal, R.R., II, Gough, L.P., and Weber-Scannell, Phyllis, 2003, Results of elemental and stable isotopic measurements, and dietary composition of Arctic grayling collected in 2000 and 2001 from the Fortymile River Watershed, Alaska: U.S. Geological Survey Open-File Report 03-57, $28 \mathrm{p}$.

Day, W.C., Gamble, B.M., Henning, M.W., and Smith, B.D., 2000 , Geologic setting of the Fortymile River area-polyphase deformational history within part of the eastern Yukon-Tanana upland of Alaska, in Kelley, K.D., and Gough, L.P., eds., Geologic studies in Alaska by the U.S. Geological Survey, 1998: U.S. Geological Survey Professional Paper 1615, p. 65-82.

Deegan, L.A., Peterson, B.J., Golden, Heather, McIvor, C.C., and Miller, M.C., 1997, Effects of fish density, and river fertilization on algal standing stocks, invertebrate communities and fish production in an Arctic river: Canadian Journal of Fisheries and Aquatic Science, v. 54, p. 269-283.

DeNiro, M.J., and Epstein, Samuel, 1978, Influence of diet on the distribution of carbon isotopes in animals: Geochimica et Cosmochimica Acta, v. 42, no. 5, p. 495-506.

DeNiro, M.J., and Epstein, Samuel, 1981, Influence of diet on the distribution of nitrogen isotopes in animals: Geochimica et Cosmochimica Acta, v. 45, no. 3, p. 341-351.

Doucett, R.R., Hooper, W., and Power, G., 1999, Identification of anadromous and nonanadromous adult brook trout and their progeny in the Tabusintac River, New Brunswick, by means of multiple-stable-isotope analysis: American Fisheries Society Transactions, v. 128, p. 278-288.

Duffy, L.K., Scofield, E., Rodgers, T., Patton, M., and Bowyer, R.T., 1999, Comparative baseline levels of mercury, Hsp 70 and Hsp 60 in subsistence fish from the Yukon-Koskokwim delta region of Alaska: Comparative Biochemistry and Physiology, v. 124, p. 181-186.

Farrell, A.P., Hodaly, A.H., and Wang, S., 2000, Metal analysis of scales taken from Arctic grayling: Archives of Environmental Contamination and Toxicology, v. 39, p. 515-522.

France, R.L., 1995, Critical examination of stable isotope analysis as a means for tracing carbon pathways in stream ecosystems: Canadian Journal of Fisheries and Aquatic Sciences, v. 52, p. 651-656.

France, R.L., 1996, Scope of use of stable carbon isotopes in discerning the incorporation of forest detritus in aquatic foodwebs: Hydrobiologia, v. 325, p. 219-222.

Gamble, B.M., Day, W.C., and Henning, M.W., 2001, Geochemistry of lithologic units, Fortymile River study area, 
east-central Alaska, in Gough, L.P., and Wilson, F.H., eds., Geologic studies in Alaska by the U.S. Geological Survey, 1999: U.S. Geological Survey Professional Paper 1633, p. 127-134.

Gough, L.P., Crock, J.G., Day, W.C., and Vohden, Jim, 2001, Biogeochemistry of arsenic and cadmium, Fortymile River watershed, east-central Alaska, in Gough, L.P., and Wilson, F.H., eds., Geologic studies in Alaska by the U.S. Geological Survey, 1999: U.S. Geological Survey Professional Paper 1633, p. 109-126.

Grabacki, S.T., 1981, Effects of exploitation on the population dynamics of Arctic grayling in the Chena River, Alaska: Fairbanks, University of Alaska, M.S. thesis.

Gray, J.E., Meier, A.L., O'Leary, R.M., Outwater, Carol, and Theodorakos, P.M., 1996, Environmental geochemistry of mercury deposits in southwestern Alaska-mercury contents in fish, stream-sediment, and stream-water samples, in Moore, T.E., and Dumoulin, J.A., eds., Geologic studies in Alaska by the U.S. Geological Survey, 1994: U.S. Geological Survey Bulletin 2152, p. 17-29.

Gray, J.E., Theodorakos, P.M., Bailey, E.A., and Turner, R.R., 2000 , Distribution, speciation, and transport of mercury in stream-sediment, stream-water, and fish collected near abandoned mercury mines in southwestern Alaska, USA: Science of the Total Environment, v. 260, p. 21-33.

Hershey, A.E., Bowden, W.B., Deegan, L.A., Hobbie, J.E., Peterson, B.J., Kipphut, G.W., Kling, G.W., Lock, M.A., Merritt, R.W., Miller, M.C., Vestal, J.R., and Schuldt, J.A., 1997, The Kuparuk River-a long-term study of biological and chemical processes in an Arctic river, in Milner, A.M., and Oswood, M.W., eds., Freshwaters of Alaska; ecological syntheses (Ecological Studies, v. 119): New York, Springer, p. 107-129.

Hesslein, R.H., Capel, M.J., Fox, D.E., and Hallard, K.A., 1991, Stable isotopes of sulfur, carbon, and nitrogen as indicators of trophic level and fish migration in the lower Mackenzie River basin, Canada: Canadian Journal of Fisheries and Aquatic Sciences, v. 48, p. 2258-2265.

Hesslein, R.H., Hallard, K.A., and Ramlal, P.S., 1993, Replacement of sulfur, carbon, and nitrogen in tissue of growing broad whitefish (Coregonus nasus) in response to a change in diet traced by $\delta^{34} \mathrm{~S}, \delta^{13} \mathrm{C}$, and $\delta^{15} \mathrm{~N}$ : Canadian Journal of Fisheries and Aquatic Sciences, v. 50, p. 2071-2076.

Hicks, B.J., 1997, Food webs in forest and pasture streams in the Waikato region, New Zealand; a study based on analyses of stable isotopes of carbon and nitrogen, and fish gut contents: New Zealand Journal of Marine and Freshwater Research, v. 31, p. 651-664.

Hilderbrand, G.V., Farley, S.D., Robbins, C.T., Hanley, T.A., Titus, K., and Servheen, C., 1996, Use of stable isotopes to determine diets of living and extinct bears: Canadian Journal of Zoology, v. 74, p. 2080-2088.

Hobson, K.A., 1999, Tracing origins and migration of wildlife using stable isotopes; a review: Oecologia, v. 120, p. 314-326.

Hudson, R.J.M., Gherini, S.A., Watras, C.J., and Porcella, D.B., 1994, Modeling the biogeochemical cycle of mercury in lakes - the mercury cycling model (MCM) and its application to the MTL study lakes, in Watras, C.J., and Huckabee, J.W., eds., Mercury pollution-integration and synthesis: Boca Raton, Fla., Lewis, p. 473-523.

Hughes, N.F., 1999, Population processes responsible for larger-fish upstream distribution patterns of Arctic grayling (Thymallus arcticus) in interior Alaskan runoff rivers: Canadian Journal of Fisheries and Aquatic Science, v. 56, p. 2292-2299.

Kennedy, K.R., and Crock, J.G., 1987, Determination of mercury in geological materials by continuous-flow, cold-vapor, atomic absorption spectrophotometry: Analytical Letters, v. 20, p. 899-908.

Kline, T.C., Goering, J.J., and Piorkowski, R.J., 1997, The effect of salmon carcasses on Alaskan freshwaters, in Milner, A.M., and Oswood, M.W., eds., Freshwaters of Alaska; ecological syntheses (Ecological Studies, v. 119): New York, Springer, p. 179-204.

Kostohrys, Jon, Sterin, B.B.G., and Hammond, Tim, 1999, Water resources of the Fortymile National Wild and Scenic River, Alaska: U.S. Bureau of Land Management Open-File Report 75, 64 p.

Lindberg, S.E., Levin, L.A., and Porcella, D.B., eds., 2000, Proceedings of the Fifth International Conference on Mercury as a Global Pollutant, part 2: Science of the Total Environment, v. 260.

Merritt, M., 1989, Age and length studies and harvest surveys of Arctic grayling on the Seward Peninsula, 1988: Alaska Department of Fish and Game, Fishery Data Series, no. 79.

Miesch, A.T., 1976, Geochemical survey of Missouri-methods of sampling, laboratory analysis, and statistical reduction of data: U.S. Geological Survey Professional Paper 954-A, 39 p.

Minagawa, Masao, and Wada, Eitaro, 1984, Stepwise enrichment of ${ }^{15} \mathrm{~N}$ along food chains: further evidence and the relation between $\delta^{15} \mathrm{~N}$ and animal age: Geochimica et Cosmochimica Acta, v. 48, no. 8, p. 1135-1140.

Mueller, K.A., Snyder-Conn, Elaine, and Bertram, M.A., 1996, Water quality and metal and metalloid contaminants in sediments and fish of Koyukuk, Nowitna, and the northern unit of Innoko National Wildlife Refuges, Alaska, 1991: U.S. Fish and Wildlife Service Technical Report NAES-TR-96-03, 79 p. 
Ohmoto, Hiroshi, and Rye, R.O., 1979, Isotopes of sulfur and carbon, in Barnes, H.L., ed., Geochemistry of hydrothermal ore deposits: New York, John Wiley and Sons, p. 509-567.

O'Leary, M.H., 1988, Carbon isotopes in photosynthesis: Biosciences, v. 38, p. 328-335.

Paulsson, K., and Lundbergh, K., 1991, Treatment of mercury contaminated fish by selenium addition: Water, Air, and Soil Pollution, v. 56, p. 833-841.

Peterson, B.J., and Fry, Brian, 1987, Stable isotopes in ecosystem studies: Annual Reviews of Ecology and Systematics, v. 18 , p. 293-320.

Rau, G.H., 1980, Carbon-13/carbon-12 variation in subalpine lake aquatic insects; food source implications: Canadian Journal of Fisheries and Aquatic Sciences, v. 37, p. 742-745.

Reynolds, J.B., 1997, Ecology of overwintering fishes in Alaskan freshwaters, in Milner, A.M., and Oswood, M.W., eds., Freshwaters of Alaska; ecological syntheses (Ecological Studies, v. 119): New York, Springer, p. 281-302.

Reynolds, J.B., Simmons, R.C., and Burkholder, A.R., 1989, Effects of placer mining discharge on health and food of Arctic grayling: Water Resources Bulletin, v. 25, p. 625635.

Schroeder, W.H., Anlauf, K.G., Barrie, L.A., Lu, J.Y., Steffen, Alexandra, Schneeberger, D.R., and Berg, T., 1998, Arctic springtime depletion of mercury: Nature, v. 394, no. 669, p. 331-332.
Seal, R.R., II, Alpers, C.N., and Rye, R.O., 2000, Stable isotope systematics of sulfate minerals: Reviews in Mineralogy and Geochemistry, v. 40, p. 541-602.

Snyder-Conn, Elaine, Bertram, M., and Scannell, P., 1992, Contaminant data for water, sediments, and fish of Koyukuk Wildlife Refuge and the northern unit of Innoko National Wildlife Refuge: U.S. Fish and Wildlife Service Technical Report NAES-TR-92-04, 78 p.

Sorensen, E.M., 1991, Metal poisoning in fish: Boca Raton, Fla., CRC Press, 374 p.

Taggart, J.E., ed., 2002, Analytical methods for chemical analysis of geologic and other materials, U.S. Geological Survey: U.S. Geological Survey Open-File Report 02-223, n.p.

Tieszen, L.L., Boutton, T.W., Tesdahl, K.G., and Slade, N.A., 1983, Fractionation and turnover of stable carbon isotopes in animal tissues; implications for $\delta^{13} \mathrm{C}$ analysis of diet: Oecologia, v. 57, p. 32-37.

U.S. Environmental Protection Agency, 2000, Risk assessment and fish consumption limits, v. 2 of Guidance for assessing chemical contaminant data for use in fish advisories ( $3 \mathrm{~d}$ ed.): Report EPA 823-B-00-008.

West, R.L., Smith, M.W., Barber, W.E., Reynolds, J.B., and Hop, H., 1992, Autumn migration and overwintering in coastal streams of the Arctic National Wildlife Refuge, Alaska: American Fisheries Society Transactions, v. 121, p. 709-715. 



\title{
Chapter 3
}

\section{Comparative Characteristics of Natural Organic Matter in the Fortymile River, Alaska}

\author{
By Donald L. Macalady, ${ }^{1}$ Kaylene Ritter, ${ }^{1}$ Aaron D. Redman, ${ }^{1}$ and Magnus Skold ${ }^{1}$
}

\section{Contents}

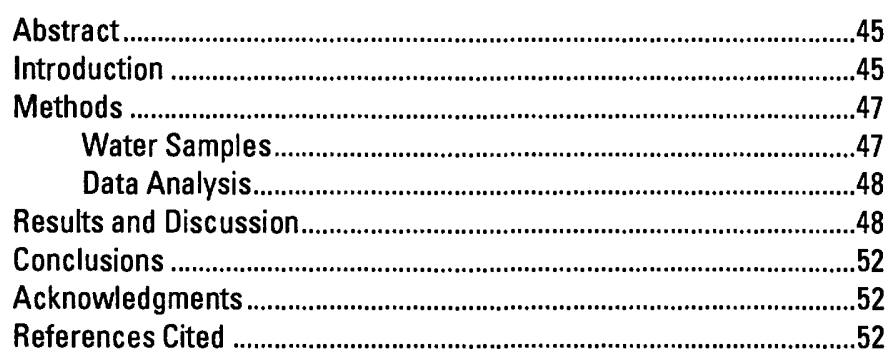

\section{Abstract}

Water samples collected from Alaska's Fortymile River and O'Brien Creek, a major tributary, were analyzed to evaluate the potential for metallic-ion mobilization caused by natural organic matter (NOM). This factor is of concern because of the high NOM concentrations in these rivers and historical and present-day mining activities in the river-drainage areas. Analyses of the samples for metallic-element contents showed nondetectable to very low trace-element concentrations, especially of those elements commonly associated with basemetal-mining activities. This result diminishes any immediate concern about metal loads in these rivers.

We have evaluated the potential for NOM-induced metallic-ion mobilization due to future mining or other anthropogenic sources by comparing the NOM concentrations of water samples from these two Alaskan streams with those of other NOM-rich waters from various sources. In fact, the two Alaskan streams are unique among the samples tested because of their very high alkalinities and elevated $\mathrm{Ca}, \mathrm{Mg}, \mathrm{Ba}$, and Sr contents, resulting from the geochemistry of the drainage basins, not from anthropogenic sources. Overall, comparisons of several measured properties of water samples from the Fortymile River and O'Brien Creek with those of other water samples suggest a minimal role for NOM/metallic-ion-

'Colorado School of Mines, Golden. complex formation in the two Alaskan streams. Measurement of the $\mathrm{Cu}$-complexation capacities for these and other NOM samples confirms that these Alaskan streams are characterized by NOM with very low metallic-ion-complexation capacities. These results clearly suggest that the NOM in these two Alaskan streams has only a minimal potential for metallic-ion mobilization.

\section{Introduction}

Natural organic matter (NOM) is abundant in the drainage of many Alaskan rivers and streams, including the Fortymile River and several of its tributaries. This factor is of special interest for the Fortymile River drainage area because of widespread current and historical placer gold-mining operations in the river and its riparian zones. NOM is known to sequester cationic metals in solution, thus increasing their mobility and ease of transport (Macalady and Ranville, 1998). Recent evidence suggests that NOM can increase the mobility of anionic metalloids, such as arsenic (Redman and others, 2002). As we show below, metallic-ion concentrations in waters of the Fortymile River drainage are not of current concern. Nevertheless, it is prudent to investigate questions surrounding the possible role of NOM in determinations of metallic-ion mobility so as to set a baseline against which anthropogenic impacts can be compared.

NOM samples represent inherently complex mixtures of polyfunctional organic acids and phenols with properties that vary considerably, depending on the origin and pretreatment of the samples (MacCarthy, 2001; Macalady and Ranville, 1998). The phrase "humic substances" has generally been applied to operationally defined components of soil or solution-phase NOM. Humic substances have the seemingly contradictory properties of recalcitrance to further degradation and reactive lability with respect to oxidation/reduction reactions, metallicion complexation, and molecular configurations.

Humic acids, fulvic acids, humin, and hydrophilic acids are among the operationally defined isolates of NOM that are 
commonly used to investigate the roles and functions of NOM in natural and polluted environments. The use of isolates has the advantage that a sample of fulvic acid, for example, from a given soil or aquatic system can be expected to have relatively constant chemical and physical properties over time because the more geochemically and biologically labile NOM components, as well as the inorganic matrix, have been removed during the isolation procedures. Standardized samples of humic and fulvic acids are commercially available through the International Humic Substances Society, among other sources. Also, as a consequence of the standardized isolation procedures (Thurman and Malcolm, 1981), samples of fulvic acid from various sources generally are more similar than might be expected for the bulk NOM samples from which the fulvic acids were derived (McKnight and others, 1983). Thus, much of the reported research involving NOM actually involves the use of one or more of these operationally defined fractions.

Particularly for solution-phase NOM, these defined fractions (humic materials) constitute only about half of the organic $\mathrm{C}$ in most aquatic systems. This fact represents one obvious disadvantage of using such isolates as fulvic, humic, or hydrophilic acids for investigating the roles and influences of NOM in natural systems. The suite of molecules composing the whole of an NOM sample may behave quite differently from the fulvic acid, for example, derived from the same aquatic system, partly because the fraction is only part of the whole but also because the influences of inorganic constituents in the aquatic system are obviated. Finally, no evidence has been observed to support the notion that the various defined fractions represent unaltered portions of the original NOM. Because aspects of molecular behavior related to molecular conformations may be critical for NOM, removal of a fraction from the whole may alter the behavior of both the isolate and the remaining fraction.

Thus, unlike fulvic acid, the organic components of whole, NOM-rich waters from diverse environments vary widely in their ability to form stable metallo-organic complexes. This variety can be reflected in the native metallic-ion concentrations of NOM, or in the ability of the NOM to complex additional metallic ions from solution or from material adsorbed onto, or precipitated with, solid-phase minerals. For example, when NOM-rich water samples (all adjusted to a $\mathrm{pH}$ of 6.0 and diluted to a dissolved-organic-carbon (DOC) content of $10 \mathrm{mg} / \mathrm{L}$ ) from various sources were spiked with $3 \mu M \mathrm{Cu}$, free (electrochemically labile, noncomplexed) $\mathrm{Cu}$ (II) contents ranged over almost two orders of magnitude (Skold, 1999). This $\mathrm{Cu}$ content, equivalent to $200 \mu \mathrm{g} / \mathrm{L}$, is not unreasonable for waters contaminated by mining activities (Peiffer and others, 1998). Thus, even at relatively low metallic-ion concentrations, the ability of NOM to complex metals varies significantly when the NOM source is considered-from almost all present in a complexed form to about 90 percent free (labile).

The (total dissolved) metallic-ion concentrations of NOM-rich natural waters show a comparable variety (see below). In this regard, the levels of "dissolved" (operationally defined) metals that are sparingly soluble in the absence of NOM or other solution-phase complexing agents are particularly instructive. $\mathrm{Fe}$ (III) is especially useful in this regard because equilibrium $\mathrm{Fe}$ (III) contents are expected to be immeasurably low over the $\mathrm{pH}$ range relevant to natural waters (for example, Macalady and others, 1990). Waters rich in NOM are shown below to have $\mathrm{Fe}$ (III) contents that range from one sequestered $\mathrm{Fe}$ (III) ion per six $\mathrm{C}$ atoms to virtually Fe free. Such variations can reflect the geochemical environment from which the NOM was sampled and (or) the botanic and microbiologic origins of the samples.

Another NOM property of interest, with respect to the ability to sequester metals, is the fraction of NOM (as measured by organic C) that is adsorbed upon equilibration with the surfaces of such metal oxyhydroxides as hematite or gibbsite. Particularly for Fe and Al hydroxides, NOM is known to form stable surface complexes with mineral grains (McKnight and others, 1992). Under identical experimental conditions, the fractions of total organic carbon (TOC) removed for various NOM samples upon exposure to a model mineral, such as hematite, can also be used as reflections of the relative ability to form stable (surface) metallic-ion complexes.

The extent and importance of NOM metallic-ion complexation in a given aquatic system is a complex function of the composition and source of the NOM, as well as of other system characteristics, including basic mineralogy and inorganic water characteristics. Our study is part of a more extensive laboratory effort to develop a predictive methodology for assessing the relative importance of NOM and other aqueous constituents in various chemical and physical processes within aquatic systems. As a part of these investigations, we have quantified many characteristics of a wide variety of NOM-rich waters, including such standard water-quality parameters as alkalinity, $\mathrm{pH}$, conductivity, anionic composition, and metallic-ion concentration. In addition, we determined NOM-specific characteristics, all normalized to unit $\mathrm{C}$ contents, such as carboxylate acidity (defined as acidity neutralized between $\mathrm{pH} 2$ and 7), phenolic acidity (defined as acidity neutralized between $\mathrm{pH} 7$ and 10), metallic-ion-complexation capacity (defined in terms of $\mathrm{Cu}$ (II) complexation), and aromatic content (defined in terms of specific ultraviolet absorbance [SUVA] at $254 \mathrm{~nm}$ ). We also investigated the oxidation/ reduction properties of NOM.

We report here the results of investigations on waters from the Fortymile River and O'Brien Creek, a major tributary to the former, in comparison with other NOM-rich waters that have been part of our continuing studies. The specific hypothesis guiding our investigations of waters from the Fortymile River and O'Brien Creek is that the composition of the NOM present in these waters, along with associated inorganic constituents, is such that the risk of substantial metallic-ion mobilization by placer-mining operations in these waters is minimal. All of our investigations, as implied above, have been with "whole water" samples; we have made no effort to isolate NOM or to separate it into defined fractions (such as fulvic acids). We have measured native metallic-ion concentrations, but we have made no effort to remove these metals. Generally 
speaking, all samples are near neutral and have greater-thanmillimolar DOC concentrations. Because whole waters are used, other components and characteristics of each sample must be considered in addition to NOM-in other words, unambiguous ascription of all observed behaviors exclusively to NOM is outside the scope of this study.

\section{Methods}

\section{Water Samples}

Samples of Alaska river water were collected during April 2001. The water sample from the Fortymile River was obtained on April 3 in the South Fork, approximately $200 \mathrm{~m}$ above its confluence with the North Fork (lat $64^{\circ} 14.483^{\prime} \mathrm{N}$.,

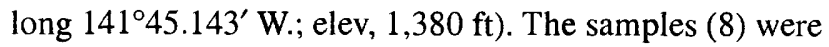
obtained through an auger-drilled hole in the ice, using a peristaltic pump, into acid-washed, 1-L-volume brown (opaque) Nalgene bottles. Bottles were thoroughly rinsed with river water before the samples were collected. At that time, the river was frozen completely, and no flow was detected. Thus, the sample probably represents a considerable freeze concentration over the river water under nonfrozen conditions. At the time of sampling, the water had a $\mathrm{pH}$ of 7.29 (measured at $0^{\circ} \mathrm{C}$ ), a conductivity of $720 \mu \mathrm{S} / \mathrm{cm}$, an undetectable Fe content $(<0.05 \mathrm{mg} / \mathrm{L})$, and a dissolved-O content of 4 to $5 \mathrm{mg} / \mathrm{L}$.

The water samples from $\mathrm{O}^{\prime}$ Brien Creek were collected several miles upriver from its confluence with the Fortymile River, approximately $150 \mathrm{~m}$ downstream from the confluence of Alder Creek with O'Brien Creek (lat 64²1.035' N., long $141^{\circ} 23.388^{\prime}$ W.) and about $30 \mathrm{~m}$ below a pronounced circular upwelling in the stream that had cleared the ice at the upwelling and in a channel below. The samples (9) were obtained by submerging 1-L-volume brown Nalgene bottles in the flowing water and rinsing several times before filling. The water had a pH of 7.90 (measured at $0.4^{\circ} \mathrm{C}$ ) and a conductivity of 1,795 $\mu \mathrm{S} / \mathrm{cm}$. Samples were transported to the Colorado School of Mines and refrigerated at $4{ }^{\circ} \mathrm{C}$ until analyzed.

We note that because the samples were not filtered and acidified in the field, alterations between the time of sampling and analysis are likely; however, no visible changes in the samples were observed during storage (that is, no staining was observed in the containers, nor were any visible precipitates formed). Nevertheless, the conclusions of this study are based on sample characteristics at the time of analysis, which may vary somewhat from field conditions.

The other water samples used in this study were collected at various times and locations (table 1). Generally, samples were collected at or near the surface of the relevant water body by submersing 2- to 10-L-volume, acid-washed plastic bottles beneath the surface, rinsing and then filling, and allowing little or no headspace. Several water samples (Inangahua River, Suwannee River, Black River) were collected by tossing a plastic bucket (with a rope attached) into a fast-flowing stream, retrieving the bucket, and filling the plastic bottles from the bucket. Samples were not preserved or altered in any deliberate way. Depending on location, samples were removed to a refrigerated $\left(4^{\circ} \mathrm{C}\right)$ site as quickly as possible; the interval between sampling and refrigeration ranged from several hours to 2 weeks. Samples from New Zealand (Inangahua, Stoney Creek) were shipped to Colorado in insulated containers by airfreight. Samples from the Rio Negro were carried as checked baggage from Brazil and left unrefrigerated for several days. Upon their arrival at the laboratory, all samples were stored until analysis at $4^{\circ} \mathrm{C}$, generally in polyethylene bottles; some samples were stored in brown glass bottles to minimize the effects of oxygen and light.

Sample MW-6 is from a shallow ( $\sim 1 \mathrm{~m}$ deep) well beneath a wetland near Leadville, Colo.; the wetland receives much of its water from two streams heavily contaminated with acid mine drainage (Peiffer and others, 1998). When pumped from the ground (using a peristaltic pump), the sample was

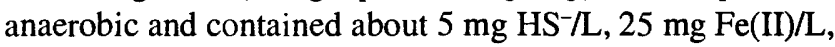
and $35 \mathrm{mg}$ DOC/L. After storage and before analysis, sample MW- 6 had been oxidized (by air) to the extent that it contained no measurable sulfide or Fe(II). The Fe content of the filtered $(0.2$ or $0.45 \mu \mathrm{m})$ water did not change upon oxidation, although all of the Fe had been converted to Fe(III). Sample characteristics and locations are summarized in table 1.

The change in NOM characteristics during storage is a nontrivial issue for whole-water samples, which necessarily contain labile organic constituents that degrade over time, either abiotically or because of microbial activity. The extent to which such changes are observable and (or) important can be expected to vary among sample locations and over time at the same location. Our laboratory observations indicate that monthly changes in measurable characteristics range from barely within statistical significance to substantial. DOC contents, for example, can fluctuate by 0 to 20 percent per year for whole-water samples stored in dark plastic containers at $4^{\circ} \mathrm{C}$. We are currently attempting to understand both these changes in DOC content and the factors affecting their magnitude. Our goal is to eventually develop storage protocols that minimize temporal variations in whole-water samples. A corollary series of investigations concerns the seasonal variation among water samples from the same locations. For the purposes of our investigations, all measurements reported here for a given water sample are on subsamples isolated at a specific time, with filtrations, $\mathrm{pH}$ and (or) ionic-strength adjustments, and dilutions, where necessary, made immediately before analysis.

Reagents used were "metal free" or high-purity commercial-grade chemicals, used as received. Potassium phthalate was used both for (daily) standardization of $\mathrm{NaOH}$ titrant solutions and for preparation of standards for DOC determinations. Measurement methods for most whole-water or NOMspecific characteristics are relatively standard and have been described elsewhere (see Skold, 1999, Redman and others, 2002, and references therein) and so are not detailed here. These measurements include DOC content, $\mathrm{pH}$, alkalinity, conductivity, carboxylate and (or) phenolic acidity, aromatic content (by SUVA), metals (by inductively coupled plasma 
Table 1. Description of sites sampled for natural-organic-matter investigations.

[See text for descriptions of the Alaska river-water samples]

\begin{tabular}{|c|c|c|}
\hline $\begin{array}{l}\text { Sample } \\
\text { identifier }\end{array}$ & Location and sampling date & Comment \\
\hline Rio Negro----.---...- & $\begin{array}{l}50 \mathrm{~km} \text { upstream from Manaus, Amazonia, } \\
\text { Brazil, July } 2000 .\end{array}$ & $\begin{array}{l}\text { Sample taken during high-water } \\
\text { period. }\end{array}$ \\
\hline Stoney Creek -..--.-- & $\begin{array}{l}\text { Central Otago, South Island, New Zealand, } \\
\text { April } 1997 .\end{array}$ & $\begin{array}{l}\text { Catchment basin is grassland, } \\
\text { totally devoid of trees. }\end{array}$ \\
\hline Inangahua River--.-- & $\begin{array}{l}\text { Westland, South Island, New Zealand, April } \\
1997 .\end{array}$ & $\begin{array}{l}\text { Catchment dominated by red } \\
\text { beech. }\end{array}$ \\
\hline Black River --------- & $\begin{array}{l}\text { Upper Michigan peninsula, near Republic, } \\
\text { Mich., July } 1999 .\end{array}$ & $\begin{array}{l}\text { River flows through Fe-rich } \\
\text { terrain. }\end{array}$ \\
\hline Suwannee River----- & $\begin{array}{l}\text { At weir defining outlet of the Okeefenokee } \\
\text { Swamp, southern Georgia, August } 1994 .\end{array}$ & --- \\
\hline MW-6 - -.-.-.-.-.- & $\begin{array}{l}\text { Ground water from a shallow ( } 1 \mathrm{~m} \text { deep) } \\
\text { aquifer beneath a high-altitude wetland, } \\
\text { Leadville, Colo., August } 1994 \text {. }\end{array}$ & $\begin{array}{l}\text { Wetland is highly impacted by } \\
\text { streams contaminated with } \\
\text { acid mine drainage. }\end{array}$ \\
\hline
\end{tabular}

Table 2. Characteristics of water samples.

[Numbers in parentheses represent one standard deviation from the mean of three replicate determinations, n.a., not analyzed. Some of these data were previously reported by Redman and others (2002). DOC, dissolved organic carbon; SUVA, specific ultraviolet absorbance]

\begin{tabular}{|c|c|c|c|c|c|c|}
\hline $\begin{array}{l}\text { Sample } \\
\text { identifier }\end{array}$ & $\mathrm{pH}$ & $\begin{array}{c}\mathrm{DOC} \\
(\mathrm{mg} \mathrm{C} / \mathrm{L})\end{array}$ & $\begin{array}{c}\text { Alkalinity } \\
\left(\mathrm{mg} \mathrm{CaCO}_{3} / \mathrm{L}\right)\end{array}$ & $\begin{array}{c}\text { COOH } \\
\text { acidity } \\
\text { ( } \mu \text { equiv/mg } \\
\mathrm{C})\end{array}$ & $\begin{array}{c}\text { Phenolic } \\
\text { acidity } \\
\text { ( } \mu \text { equiv/mg C) }\end{array}$ & $\begin{array}{c}\text { SUVA } \\
(\mathrm{L} / \mathrm{mg} \mathrm{C} \\
\text { per centimeter } \\
\text { at } 254 \mathrm{~nm})\end{array}$ \\
\hline Fortymile River - - & $8.0(0.2)$ & $19.9(0.3)$ & $203(5)$ & $9.09(0.06)$ & n.a. & $0.019(0.002)$ \\
\hline O'Brien Creek -............ & $8.2(0.3)$ & $16.6(0.4)$ & $450(50)$ & $8.98(0.07)$ & n.a. & $.015(0.001)$ \\
\hline Rio Negro & $4.8(0.3)$ & $12.8(0.5)$ & n.a. & $3.69(0.05)$ & n.a. & $.040(0.005)$ \\
\hline Inangahua River-----.-.- & $5.5(0.3)$ & $11.5(0.5)$ & n.a. & $16.77(0.05)$ & n.a. & $.043(0.009)$ \\
\hline Stoney Creek -- & $7.2(0.3)$ & $8.0(2.0)$ & n.a. & $1.8(n=1)$ & 18.9 & $.095(0.004)$ \\
\hline Suwannee River-------- & $3.4(0.4)$ & $39(5)$ & n.a. & $7.15(0.06)$ & 4.2 & $.035(0.008)$ \\
\hline MW-6 & $5.4(0.3)$ & $31(4)$ & $\begin{array}{l}\text { n.a. } \\
\text { n.a. }\end{array}$ & $25.23(0.06)$ & n.a. & $.089(0.004)$ \\
\hline Black River --.--..-. & $5.2(0.3)$ & $26.5(3.0)$ & n.a. & $11.42(0.07)$ & n.a. & $.045(0.002)$ \\
\hline
\end{tabular}

atomic-emission spectroscopy [ICP-AES]), and anions (by ion chromatography). Unless otherwise specified, all analyses were on $0.45-\mu \mathrm{m}$-filtered samples, with filtration performed by using Nucleopore or similar screen filters immediately before analysis whenever possible. Before acidity titrations, all samples were thoroughly purged with $\mathrm{He}$ or $\mathrm{N}_{2}$ at a pH of 2 to eliminate any acidity due to carbonate species.

$\mathrm{Cu}$-complexation capacity was determined on samples adjusted to a pH of 6.0 and an ionic strength of $0.05 \mathrm{M}$ (as $\mathrm{KNO}_{3}$ ). Samples were diluted to approximately $10 \mathrm{mg} \mathrm{C} / \mathrm{L}$ before titration with $\mathrm{Cu}$ (II) (as copper perchlorate). Reported fractions of complexed and free $\mathrm{Cu}$ are normalized to $10.0 \mathrm{mg}$ C/L (see Skold, 1999, for details). Procedures used to investigate the (competitive) binding of NOM (and (or) As(V)) to Fe oxyhydroxides involved prepared hematite suspensions, as described by Redman and others (2002). For these measurements, samples were also adjusted to a $\mathrm{pH}$ of 6.0 , an ionic strength of $0.05 \mathrm{M}$, and a DOC content of $10 \mathrm{mg} / \mathrm{L}$.

\section{Data Analysis}

Unless otherwise indicated, the results reported below are mean values from at least three independent determinations. Uncertainties represent one standard deviation $(1 \sigma)$ from the mean. Detection limits are method or instrument specific except for ICP-AES, for which detection limits are operator determined at the time of analysis. The results reported below for water samples from elsewhere than the two Alaskan streams were obtained during the period 1998-2003 and were not necessarily obtained solely for the purposes of this study. Except where noted, data have not been previously published.

\section{Results and Discussion}

The comparisons of the water samples used in this study are listed in tables 2 and 3 . Two outstanding features of the 
Table 3. Anionic composition of water samples.

[All values in milligrams per liter $(n=2)$. Numbers in parentheses, detection limits. BDL, below detection limit]

\begin{tabular}{|c|c|c|c|c|}
\hline $\begin{array}{l}\text { Sample } \\
\text { identifier }\end{array}$ & $\begin{array}{c}\text { Chloride } \\
(0.02)\end{array}$ & $\begin{array}{l}\text { Nitrate } \\
(0.03)\end{array}$ & $\begin{array}{c}\text { Phosphate } \\
(0.06)\end{array}$ & $\begin{array}{l}\text { Sulfate } \\
(0.01)\end{array}$ \\
\hline Fortymile River ${ }^{1}$ & n.a. & n.a. & n.a. & 72 \\
\hline O'Brien Creek ${ }^{1}$ & n.a. & n.a. & n.a. & 237 \\
\hline Rio Negro & .55 & .14 & .064 & .095 \\
\hline Inangahua River-......-- & 9.36 & .028 & .054 & 1.59 \\
\hline Stoney Creek & 3.92 & .44 & .041 & .79 \\
\hline Suwannee River-........ & 7.21 & .015 & $\mathrm{BDL}$ & 1.15 \\
\hline MW-6 & .96 & 13.3 & .056 & 95.25 \\
\hline Black River -............. & 7.85 & $\mathrm{BDL}$ & .13 & 2.83 \\
\hline
\end{tabular}

'As indicated by the inductively coupled plasma atomic-emission-spectroscopic values for sulfur, the other dominant anion in these water samples is bicarbonate; thus, if all of the alkalinity comes from bicarbonate, O'Brien Creek water contains $275 \mathrm{mg} \mathrm{HCO}_{3}^{-} / \mathrm{L}$.

Table 4. Elemental concentrations in Alaska river waters.

[All values in milligrams per liter. Number in parentheses, uncertainties (average deviation for replicate analyses). All other trace metals were undetectable by inductively coupled plasma atomic-emission spectroscopy. BDL, below detection limit]

\begin{tabular}{|c|c|c|c|}
\hline Element & Fortymile River & O'Brien Creek & $\begin{array}{l}\text { Detection } \\
\text { limit }\end{array}$ \\
\hline Al-_-..---.-- & BDL & $0.04(0.02)$ & 0.02 \\
\hline B-..........- & $.03(0.01)$ & $.08(0.07)$ & .03 \\
\hline Ba -......... & $.06(0.01)$ & $.06(0.02)$ & .0005 \\
\hline $\mathrm{Ca}-\ldots$ & $50.0(0.5)$ & $96(3)$ & .04 \\
\hline $\mathrm{Cu}$ & $.0041(0.008)$ & $.0018(0.005)$ & .0007 \\
\hline Fe--..-... & $.015(0.001)$ & $.006(0.001)$ & .003 \\
\hline K & $1.77(0.03)$ & $2.19(0.07)$ & .14 \\
\hline Li & $.0060(0.0005)$ & $.0081(0.0004)$ & .002 \\
\hline Mg ------- & $14.48(0.03)$ & $51(2)$ & .003 \\
\hline $\mathrm{Mn}$ & BDL & $.059(0.003)$ & .004 \\
\hline $\mathrm{Na}$ & $13.37(0.06)$ & $6.6(0.4)$ & .08 \\
\hline S - -.......... & $24.07(0.05)$ & $79(3)$ & .04 \\
\hline $\mathrm{Sb}$ & BDL & BDL & .01 \\
\hline Sn & $.30(0.01)$ & $.11(0.01)$ & .05 \\
\hline Sr --.---..- & $.30(0.01)$ & $.11(0.01)$ & .0005 \\
\hline Zn ---.-.--- & $.031(0.05)$ & $.012(0.001)$ & .0007 \\
\hline
\end{tabular}

water samples from the two Alaskan streams in comparison with those of other NOM-rich waters are the very high alkalinity and sulfate content and the low aromatic content (by SUVA). Although alkalinities were not specifically determined by titration for many of the water samples, their $\mathrm{pH}$ and $\mathrm{Ca}, \mathrm{Mg}$, and $\mathrm{Fe}$ contents do not indicate substantial alkalinity, except in sample MW-6. The elemental compositions of the water samples, not listed in tables 4 and 5 , are below detection limits in all samples.

The low SUVA values and, presumably, aromatic content (table 2) indicate relatively "new" NOM frorn sources low in lignin and high in carbohydrates. This result suggests that such nonwoody plants as mosses and lichens may dominate the NOM content of these waters. The moderately high $\mathrm{COOH}$ acidity is also consistent with this hypothesis. Our ongoing investigations of NOM originating from the decay of mosses and lichens may confirm or refute this hypothesis about the origin of the NOM in the Alaska water samples.

The other outstanding feature of the elemental analyses is the absence of significant contents of $\mathrm{Fe}, \mathrm{Cu}, \mathrm{As}, \mathrm{Sb}$, and (or) other metals that in other locations are ordinarily associated with mining of precious metals. This result almost certainly reflects both the composition of the NOM in these samples and the absence of significant mineralization that facilitates mobility of these metallic ions. The high $\mathrm{Ca}$ and $\mathrm{Mg}$ contents, along with substantial $\mathrm{Ba}$ and $\mathrm{Sr}$ contents, reflect the important influence of sedimentary minerals in determining the behavior of aquatic systems. Calcite, dolomite, gypsum, and related 
Table 5. Elemental concentrations in natural-water samples.

[All values in milligrams per liter. Single inductively coupled plasma atomic-emission-spectroscopic analyses with triplicate injections. Same detection limits as in table 4. BDL, below detection limit]

\begin{tabular}{|c|c|c|c|c|c|c|c|}
\hline Element & $\begin{array}{l}\text { Rio } \\
\text { Negro }\end{array}$ & $\begin{array}{l}\text { Inangahua } \\
\text { River }\end{array}$ & $\begin{array}{l}\text { Stoney } \\
\text { Creek }\end{array}$ & $\begin{array}{l}\text { Suwannee } \\
\text { River }\end{array}$ & MW-6 & $\begin{array}{c}\text { MW-6 } \\
\text { duplicate }\end{array}$ & $\begin{array}{l}\text { Black } \\
\text { River }\end{array}$ \\
\hline 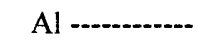 & 0.2 & 0.34 & $\mathrm{BDL}$ & 0.28 & 0.48 & 0.491 & 0.06 \\
\hline B -.--..-.-.- & .02 & .03 & .06 & .23 & .02 & .023 & .07 \\
\hline $\mathrm{Ba}$ & $\mathrm{BDL}$ & BDL & .08 & .09 & .06 & .076 & .01 \\
\hline Ca & .48 & 1.16 & 1.48 & 1.24 & 21.97 & 22.4 & 2.8 \\
\hline $\mathrm{Cu}$ & $\mathrm{BDL}$ & $\mathrm{BDL}$ & BDL & .18 & .02 & .017 & .14 \\
\hline $\mathrm{Fe}$ & .17 & .02 & .19 & .51 & 25.88 & 27.81 & .95 \\
\hline K - & BDL & $\mathrm{BDL}$ & BDL & .17 & .26 & .468 & 2.47 \\
\hline Li--.-.---.--..- & BDL & $\mathrm{BDL}$ & $\mathrm{BDL}$ & .05 & BDL & BDL & BDL \\
\hline Mg -............ & .10 & .58 & .70 & .59 & 6.34 & 6.49 & .79 \\
\hline $\mathrm{Mn}$ & $\mathrm{BDL}$ & BDL & $\mathrm{BDL}$ & $\mathrm{BDL}$ & .58 & .688 & BDL \\
\hline $\mathrm{Na}-\ldots$ & .31 & 5.98 & 3.86 & 4.11 & 6.12 & 6.761 & 2.98 \\
\hline S-- & .21 & .35 & .06 & .69 & 30.12 & 34.55 & 1.13 \\
\hline $\mathrm{S} r-\ldots$ & $\mathrm{BDL}$ & BDL & $\mathrm{BDL}$ & .03 & .02 & .064 & BDL \\
\hline $\mathrm{Zn}$ & $\mathrm{BDL}$ & $\mathrm{BDL}$ & .001 & .03 & $\mathrm{BDL}$ & .008 & .07 \\
\hline
\end{tabular}

Table 6. Cu-complexation capacity and $\mathrm{COOH}$ acidities of natural-organic-matter samples containing $10 \mathrm{mg} \mathrm{C} / \mathrm{L}$, showing the complexed fraction of total $\mathrm{Cu}\left(3.15 \times 10^{-6} \mathrm{M}, 0.2 \mathrm{mg} / \mathrm{L}\right)$.

[Specific ultraviolet absorbance (SUVA) and undiluted-sample dissolved-organic-carbon (DOC) content are shown for comparative purposes. Uncertainties in SUVA and DOC content are listed in table 2. Bound-Cu fraction is determined from single-titration trials, with estimated uncertainties of \pm 10 percent. Note that SUVA and DOC values may vary slightly from those listed in table 2 because experiments were performed at different times on different samples (that is, obtained at different times from those in table 2) or subsamples]

\begin{tabular}{|c|c|c|c|c|}
\hline Water source & SUVA & $\begin{array}{c}\mathrm{DOC} \\
(\mathrm{mg} \mathrm{C} / \mathrm{L})\end{array}$ & $\begin{array}{l}\text { Bound-Cu } \\
\text { fraction }\end{array}$ & $\begin{array}{c}\text { COOH } \\
\text { acidity } \\
\left(\begin{array}{c}\text { equiv/mg } \\
\mathrm{C})\end{array}\right.\end{array}$ \\
\hline Fortymile River - & 0.019 & 19.9 & 0.45 & 9.1 \\
\hline O'Brien Creek - & .015 & 16.6 & .50 & 9 \\
\hline Suwannee River-........- & .031 & 44 & .691 & 7.15 \\
\hline Inangahua River--......... & .039 & 11.5 & .858 & 16.77 \\
\hline Hyde County, N.C & .043 & 8.9 & .914 & -- \\
\hline Rio Negro - & .045 & 8.3 & .919 & 3.69 \\
\hline $\begin{array}{l}\text { Mossy Burn River, New } \\
\text { Zealand. }\end{array}$ & .05 & 11.5 & .902 & -- \\
\hline $\begin{array}{l}\text { Sunset Beach State Park, } \\
\text { Oreg. (seep). }\end{array}$ & .062 & 20.1 & .797 & -- \\
\hline MW-6 (ground water) -...- & .085 & 28.1 & .916 & 25.23 \\
\hline Stoney Creek -................. & .095 & 2.1 & .982 & 1.8 \\
\hline $\begin{array}{l}\text { Sutton Stream, New } \\
\text { Zealand. }\end{array}$ & .089 & 5.7 & .822 & 1.7 \\
\hline Black River -- & .045 & 26.5 & .437 & 11.41 \\
\hline
\end{tabular}

minerals must be significant in the region. The relatively high Sn content in these samples is probably related to these rock origins.

A corollary to these observations is the apparent absence of the influence of Fe minerals in these river catchments, suggesting that if hard-rock mining, which exposes pyrite-rich minerals to the atmosphere and surface waters, becomes active in this region, these data provide little assurance that enhanced mobility of toxic metals will not be a problem.
The results of $\mathrm{Cu}$ titrations to determine the extent to which NOM samples can form solution-phase $\mathrm{Cu}$ complexes are listed in table 6, along with data from several natural-water samples not listed in tables 1 and 2 that are included here to expand the data set (Skold, 1999). The Alaska water samples have $\mathrm{Cu}$-complexation abilities that are among the lowest of all the samples analyzed. These samples are quite similar in several regards to the Black River water sample, which is the only other high-latitude sample in the data set. In fact, 
the catchment vegetation in the Black River drainage basin is dominated by sphagnum bogs and conifer/willow species, similar to that in the Alaska river drainages. The Black River water sample shows a similarly low SUVA value, and $\mathrm{Cu}$-complexation capacity has been related in general to the aromatic fraction of NOM (Skold, 1999). The low metallic-ion-complexation capacity of the Alaska water samples also indicates that this NOM is unlikely to be a causative agent for increased metallic-ion mobility in these aquatic systems.

The extent to which DOC and the aromatic fraction of DOC are removed by adsorption/surface complexation with Fe minerals in natural aquatic systems is indicated in table 7 , which lists the reductions in SUVA value and TOC content upon equilibration with $500-\mathrm{mg} / \mathrm{L}$ suspensions of colloidal hematite (Redman and others, 2002). Note that the Fortymile River water sample showed the lowest tendency to adsorb to, or form surface complexes with, colloidal hematite. The Black River water sample shows similar DOC fractionation upon exposure to hematite. The data in table 7 reflect a similar tendency to those illustrated by the data in table 6 , in that the mechanisms of formation for surface complexes with Fe(III) minerals are not expected to be dissimilar to those for the formation of solution-phase metallic-ion complexes.

These data, along with additional SUVA data at $280 \mathrm{~nm}$, are illustrated in figure 1 , which clearly shows the uniqueness of the Fortymile River water sample among the suite of NOM samples analyzed. The figure also highlights that removal of the aromatic fraction from the NOM in the Fortymile River water sample is significantly less than for any other represented NOM sample. This result again reflects the relatively low ability of South Fork NOM to form metallic-ion complexes, because the aromatic fractions are known to be among the most active in metallic-ion complexation (Skold, 1999).

The final data to be mentioned here concerning the characteristics of the Alaska water samples are from Redman and others (2002), who reported the ability of NOM-rich waters to alter the otherwise-complete adsorption of $\mathrm{As}$ (III)
Table 7. Percent removal of natural organic matter and aromatic portion of natural organic matter upon exposure to $500 \mathrm{mg}$ of colloidal hematite per liter.

[All values are averages of replicate trials in a single experiment Variations are less than 10 percent]

\begin{tabular}{|c|c|c|}
\hline $\begin{array}{l}\text { Sample } \\
\text { identifier }\end{array}$ & $\begin{array}{l}\text { Absorbance } \\
\text { at } 254 \mathrm{~nm} \\
\text { (pct) }\end{array}$ & $\begin{array}{l}\text { DOC } \\
\text { removal } \\
\text { (pct) }\end{array}$ \\
\hline Rio Negro --........- & 36.6 & 26.4 \\
\hline Fortymile River -...... & 12.3 & 7.7 \\
\hline Black River & 23.5 & 7.7 \\
\hline MW-6 & 38.7 & 27.4 \\
\hline Suwannee River-....... & 25.2 & 23.6 \\
\hline Inangahua River------ & 30.8 & 16.1 \\
\hline
\end{tabular}

and $\mathrm{As}(\mathrm{V})$ species onto colloidal hematite. This behavior is registered in terms of the ability of NOM samples to liberate hematite-bound $\mathrm{As}(\mathrm{III})$ or $\mathrm{As}(\mathrm{V})$ into solution. The experiments involved NOM-rich waters (a suite similar to that listed in tables 1 and 2) diluted to $10 \mathrm{mg} \mathrm{C} / \mathrm{L}$ and adjusted to a $\mathrm{pH}$ of $6.0,1.0 \mu \mathrm{M} \mathrm{As}$, and $300-\mathrm{mg} / \mathrm{L}$ suspensions of colloidal hematite. NOM was shown to liberate 5 to $15 \mu \mathrm{g}$ As/L from hematite onto which either As(III) or As(V) had been adsorbed, presumably due to competitive adsorption and (or) the formation of solution-phase As-NOM complexes. The same NOM samples, when adsorbed onto hematite, were able to prevent the complete adsorption of $\mathrm{As}(\mathrm{III})$ or $\mathrm{As}(\mathrm{V})$ onto hematite, leaving similar As contents in solution.

Contrary to other investigated properties, the ability of Fortymile River water to liberate hematite-bound As does not appear to be unique. In the absence of hematite, Fortymile River water shows virtually no ability to form solution-phase complexes with $\mathrm{As}(\mathrm{V})$ - different from all the other samples tested. However, Fortymile River water forms solution-phase

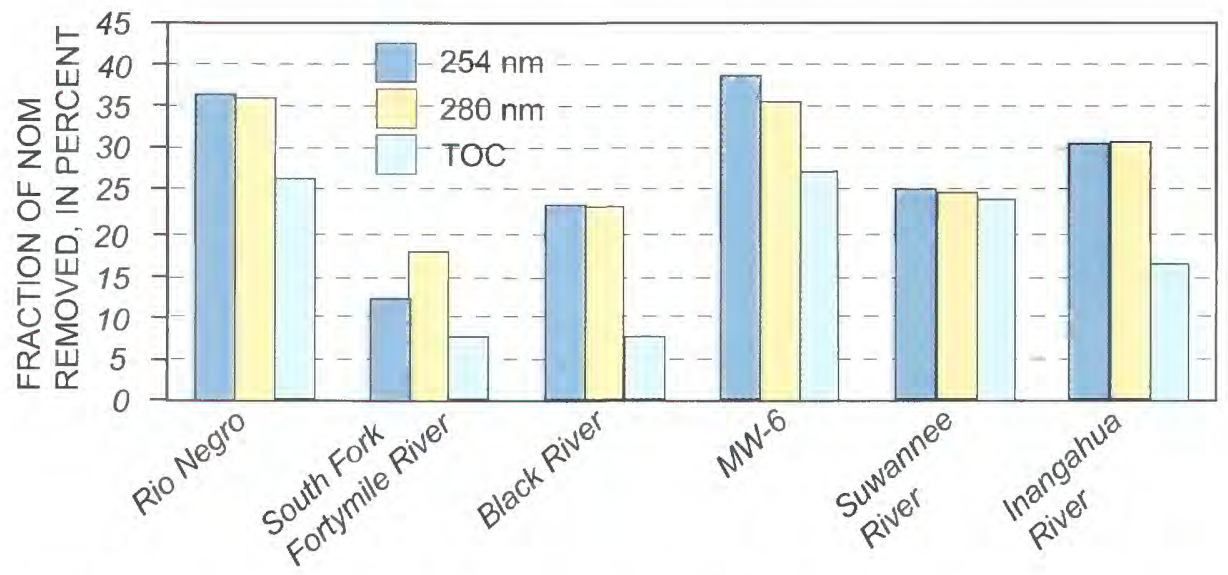

Figure 1. Fractionation of natural organic matter (NOM) by adsorption onto colloidal hematite in $0.01 \mathrm{M} \mathrm{NaCl}$ at a pH of 6.0. See table 1 for locations and descriptions of sites. TOC, total organic carbon. 
complexes with As(III) to an extent comparable to that of several other NOM samples, and so it may most closely resemble Black River NOM in this regard. The mechanisms of these As/hematite/NOM interactions are unclear and require more detailed investigation.

\section{Conclusions}

The NOM constituents present in the two Alaskan rivers sampled in April 2002 are unique in their extremely low trace-element contents and their relatively low ability to form metallo-organic complexes. These waters have a very high alkalinity and sulfate content, with concomitantly high $\mathrm{Ca}$ and $\mathrm{Mg}$ contents, somewhat complicating interpretation of the observed metallic-ion-complexation behavior and possibly masking the role of NOM in these processes. Nevertheless, the composition of these waters and their NOM is ideal insofar as minimizing trace-metallic-ion mobilization is concerned. In several aspects, as summarized above, the NOM samples from these waters represent end members in the spectrum of observed NOM behaviors.

Oxidation/reduction behavior, which is one important aspect of NOM that has not been investigated to any extent for the Alaska water samples in this study, could have important contributions to the overall influence of NOM in these waters. This behavior is the subject of continuing investigation in our laboratory.

\section{Acknowledgments}

We are grateful for the laboratory assistance by students Fabio Parolin, Stephanie Fevig, Valerie Strassberg, and James Mosby. Larry and June Taylor were gracious and helpful hosts during the sampling operations. Thanks to Larry Gough, Bronwen Wang, and Richard Wanty for their valuable assistance with logistics and operations during the sampling trip, and to the USGS for providing the opportunity to conduct the sampling and for supporting the overall idea of this project.

\section{References Cited}

Dunnivant, F.M., Schwarzenbach, R.A., and Macalady, D.L., 1992, Reduction of substituted nitrobenzenes in aqueous solutions containing natural organic matter: Environmental Science and Technology, v. 26, p. 2133-2141.

MacCarthy, Patrick, 2001, The principles of humic substances: Soil Science, v. 166, no. 11, p. 738-751.

Macalady, D.L., Langmuir, Donald, Grundl, T.J., and Elzerman, A.W., 1990, Use of model-generated $\mathrm{Fe}^{3+}$ ion activities to compute Eh and ferric oxyhydroxide solubilities in anaerobic systems, in Melchior, D.C., and Bassett, R.L., eds., Chemical modeling of aqueous systems II (ACS Symposium Series, v. 416): Washington, D.C., American Chemical Society, p. 350-367.

Macalady, D.L., and Ranville, J.F., 1998, The chemistry and geochemistry of natural organic matter, chap. 5 of Macalady, D.L., ed., Perspectives in environmental chemistry: New York, Oxford University Press.

McKnight, D.M., Feder, G.L., Thurman, E.M., Wershaw, R.L., and Westall, J.C., 1983, Complexation of copper by aquatic humic substances from different environments, in Wildung, R.E., and Jenne, E.A., eds., Biological activity of trace metals: Amsterdam, Elsevier, p. 65-76.

McKnight, D.M., Bencala, K.E., Zellweger, G.W., Aiken, G.R., Feder, G.L., and Thorn, K.A., 1992, Sorption of dissolved organic carbon by hydrous aluminum and iron oxides occurring at the confluence of Deer Creek and the Snake River, Summit County, Colorado: Environmental Science and Technology, v. 26, p. 1388-1398.

Peiffer, Stefan, Walton-Day, Katherine, and Macalady, D.L., 1998, The interaction of natural organic matter with iron in a wetland (Tennessee Park, $\mathrm{CO}$ ) receiving acid mine drainage: Aquatic Geochemistry, v. 5, no. 2, p. 207-233.

Redman, A.D., Macalady, D.L., and Ahmann, Dianne, 2002, Natural organic matter affects arsenic speciation and sorption onto hematite: Environmental Science and Technology, v. 36 , p. $2889-2896$.

Skold, Magnus, 1999, Copper complexation by natural organic matter as related to sample origin: Golden, Colorado School of Mines, M.S. thesis, 127 p.

Thurman, E.A., and Malcolm, R.L., 1981, Preparative isolation of aquatic humic substances: Environmental Science and Technology, v. 15, p. 463-466. 


\section{Chapter 4}

\section{U.S. Geological Survey Reports on the Fortymile River Watershed-Products of Recent Mineral Resources Program Studies}

Crock, J.G., Gough, L.P., Wanty, R.B., Day, W.C., Wang, Bronwen, Gamble, B.M., Henning, M.W., Brown, Z.A., and Meier, A.L., 1999, Regional geochemical results from the analysis of rock, water, soil, stream sediment, and vegetation samples-Fortymile River Watershed, east-central, Alaska, 1997 sampling: U.S. Geological Survey Open-File Report 99-33, 82 p.

Crock, J.G., Gough, L.P., Wanty, R.B., Day, W.C., Wang, Bronwen, Gamble, B.M., Henning, M.W., Brown, Z.A., and Meier, A.L., 2000, Regional geochemical results from the analyses of rock, water, soil, stream sediment, and vegetation samples-Fortymile River watershed, east-central, Alaska, 1998 sampling: U.S. Geological Survey Open-File Report 00-511, 157 p.

Crock, J.G., Larison, J.R., and Gough, L.P., 2000, Cadmium accumulation in native vegetation of Alaska and Colorado, in Centeno, J.A., Collery, Phillip, Vernet, Guy, Finkelman, R.B., Gibb, Herman, and Etienne, J.C., eds., Metal ions in biology and medicine, v. 6 of International Symposium on Metal Ions in Biology and Medicine, 6th, San Juan, Puerto Rico, 2000: Paris, John Libby Eurotext, p. 177-179.

Crock, J.G., Seal, R.R., Gough, L.P., and Weber-Scannell, Phyllis, 2003, Results of elemental and stable isotopic measurements, and dietary composition of Arctic grayling (Thymallus arcticus) collected in 2000 and 2001 from the Fortymile River watershed, Alaska: U.S. Geological Survey Open-File Report 03-057, 28 p. [URL http: //pubs.usgs.gov/of/2003/ofr-03-057/].

Day, W.C., Aleinikoff, J.N., Dusel-Bacon, Cynthia, Goldfarb, R.J., Gough, L.P., and O'Neill, J.M., 2002, Complex Mesozoic deformation in the central part of the YukonTanana Upland, Alaska-implications for gold deposition in the Tintina Gold Province [abs.]: Geological Society of America Program and Abstracts, v. 34, no. 6, p. 114.

Day, W.C., Aleinikoff, J.N., and Gamble, B.M., 2002, Geochemistry and age constraints on metamorphism and deformation of the Fortymile River area, eastern YukonTanana Upland, Alaska, in Wilson, F.H., and Galloway, J.P., eds., Studies by the U.S. Geological Survey in Alaska, 2000: U.S. Geological Survey Professional Paper 1662, p. 5-18.

Day, W.C., Aleinikoff, J.N., Henning, M.W., Gamble, B.M., and Gough, L.P., 2002, Overview of the bedrock geologic setting of the Big Delta B-2 Quadrangle, Alaska: Alaska Miners Association Conference, 18th, Fairbanks, 2002, Program and Abstracts, p. 10-11.

Day, W.C., Gamble, B.M., Henning, M.W., and Smith, B.D., 2000, Geologic setting of the Fortymile River area polyphase deformational history within part of the eastern Yukon-Tanana Upland, Alaska, in Kelley, K.D., and Gough, L.P., eds., Geologic studies in Alaska by the U.S. Geological Survey, 1998: U.S. Geological Survey Professional Paper 1615 , p. 65-82.

Day, W.C., Wanty, R.B., Gamble, B.M., Henning, M.W., Crock, J.G., and Gough, L.P., 1998, Geology and regional surface-water quality of the Fortymile Mining District, Yukon-Tanana Upland, Alaska [abs.]: Geological Society of America Annual Meeting, Toronto, 1998, Abstracts with Programs, p. 103.

Gamble, B.M., Day, W.C., and Henning, M.W., 2001, Geochemistry of lithologic units, Fortymile River study area, east-central Alaska, in Gough, L.P., and Wilson, F.H., Geologic studies in Alaska by the U.S. Geological Survey, 1999: U.S. Geological Survey Professional Paper 1633, p. 127-134.

Gough, L.P., Crock, J.G., Day, W.C., Vohden, Jim, 2001, Biogeochemistry of arsenic and cadmium, Fortymile River watershed, east-central Alaska, in Gough, L.P., and Wilson, F.H., eds., Geologic studies in Alaska by the U.S. Geological Survey, 1999: U.S. Geological Survey Professional Paper 1633, p. 109-126. 
Gough, L.P., Crock, J.G., Wang, Bronwen, Weber-Scannell, Phyllis, and Seal, R.R., 2002, Biogeochemistry of Arctic grayling (Thymallus arcticus) in the Fortymile River Mining District, Alaska [abs.]: Geological Society of America Program and Abstracts, v. 34, no. 6, p. 144.

Gough, L.P., Crock, J.G., Wanty, R.B., Day, W.C., Wang, Bronwen, and Gamble, B.M., 1999, Regional geochemical cycling of cadmium and associated elements, Fortymile River Mining District, east-central, Alaska [abs.], in KabataPendias, Alina, and Szteke, Barbara, eds., Conference on Cadmium in the Environment, 3d, Warsaw, 1999: Polish Academy of Sciences Publication 6C, p. 12.

Gough, L.P., Day, W.C., Crock, J.G., Gamble, B.M., and Henning, M.W., 1997, Placer gold mining in Alaska-cooperative studies on the effect of suction dredge operations on the Fortymile River: U.S. Geological Survey Fact Sheet 155-97, 4 p. [URL http://minerals.usgs.gov/product.html].

Gough, L.P., Wanty, R.B., and Henning, M.W., 1997, Water quality studies of suction dredge gold-placer mining operations along the Fortymile River, eastern Alaska [abs.]: Alaska Miners Association Annual Meeting, Anchorage, 1997, Proceedings, p. 29-30.

Gough, L.P., Wanty, R.B., Wang, Bronwen, Crock, J.G., Day, W.C., Gamble, B.M., and Henning, M.W., 1999, Regional geochemical studies related to placer gold resources, Fortymile River area, east-central Alaska [abs.]: Geological Society of America Abstracts with Programs, v. 31, no. 6, p. 58.
Wang, Bronwen, Gough, L.P., Crock, J.G., and Day, W.C., 2001, Biogeochemistry of As and Cd in eolian sub-arctic soils, Yukon-Tanana Upland, Alaska [abs.]: International Conference on the Biogeochemistry of Trace Elements, Guelph, Ontario, Canada, 2001, Proceedings, p. 333.

Wanty, R.B., Wang, Bronwen, Day, W.C., Vohden, Jim, Crock, J.G., Gough, L.P., Gamble, B.M., Smith, B.D., and Henning, M.W., 2002, Influence of geologic features on hydrology and geochemistry near the Pogo Gold Deposit, eastern Alaska: Alaska Miners Association Conference, 18th, Fairbanks, 2002, Program and Abstracts, p. 12-14.

Wanty, R.B., Wang, Bronwen, and Vohden, Jim, 1997, Studies of suction dredge gold-placer mining operations along the Fortymile River, eastern Alaska: U.S. Geological Survey Fact Sheet 154-97 [URL http://minerals.usgs.gov/ product.html].

Wanty, R.B., Wang, Bronwen, Vohden, Jim, Briggs, P.H., and Meier, A.L., 2000, Regional baseline geochemistry and environmental effects of gold-placer mining operations on the Fortymile River, eastern Alaska, in Kelley, K.D., and Gough, L.P., eds., Geologic studies in Alaska by the U.S. Geological Survey, 1998: U.S. Geological Survey Professional Paper 1615, p. 101-110.

Wanty, R.B., Wang, Bronwen, Vohden, Jim, Day, W.C., and Gough, L.P., 2002, Aufeis accumulations in stream bottoms in Arctic and subarctic environments as an indicator of geologic structure [abs.]: Geologic Society of America Program and Abstracts, v. 34 , no. 6, p. 347. 





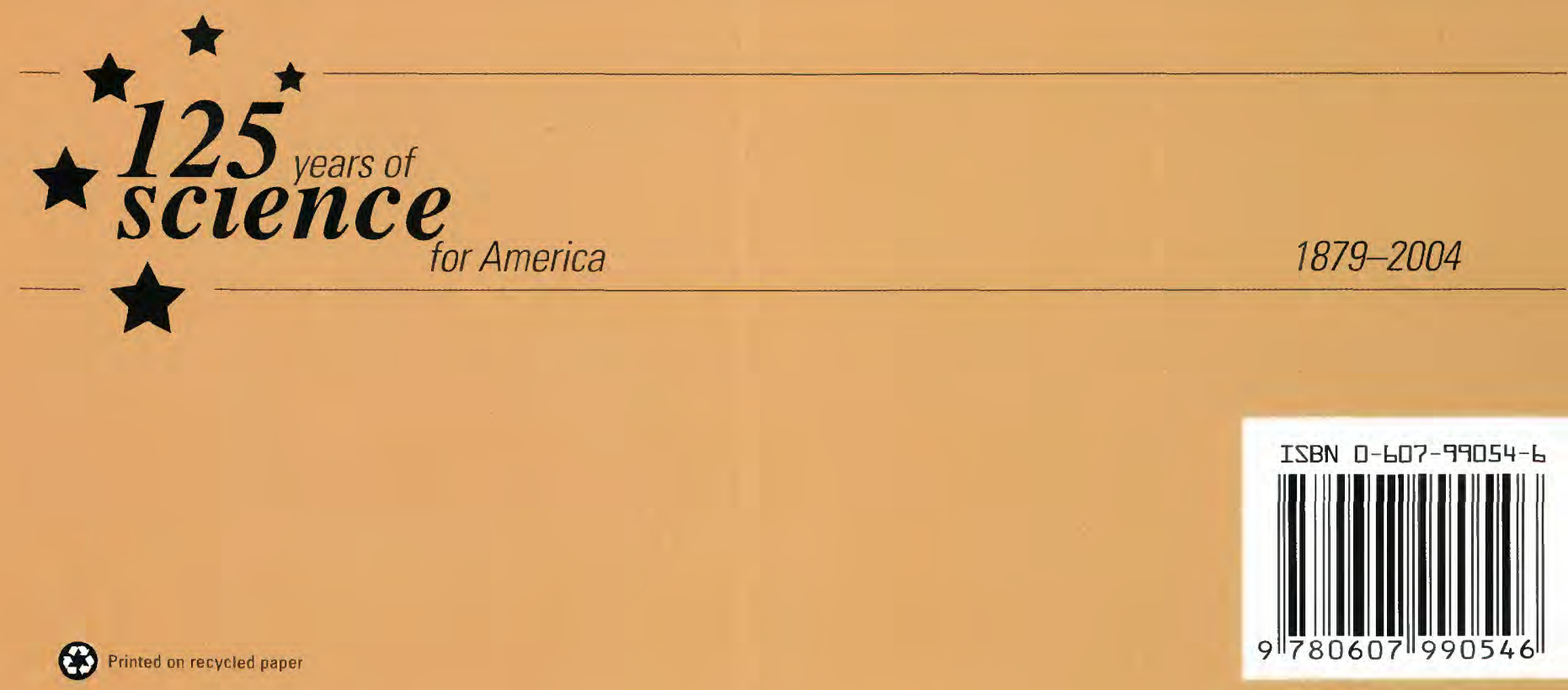

